\title{
NOTES ON THE GEOLOGY OF TIBET AND ADJACENT AREAS-- \\ REPORT OF THE AMERICAN PLATE TECTONICS DELEGATION \\ TO THE PEOPLE'S REPUBLIC OF CHINA
}
A. W. Bally ${ }^{7}$, C. R. Allen ${ }^{2}$, R. B. Geyer ${ }^{3}$, W. B. Hamilton ${ }^{4}$, C. A. Hopson ${ }^{5}$,
P. H. Molnar ${ }^{6}$, J. E. 01iver ${ }^{7}$, N. D. Opdyke ${ }^{8}$, G. Plafker ${ }^{4}$, and F. T. Wu ${ }^{9}$

IShell 0il Company

${ }^{2}$ California Institute of Technology

${ }^{3}$ National Academy of Sciences

${ }^{4} U$. S. Geological Survey

${ }^{5}$ University of California, Santa Barbara

6 Massachusetts Institute of Technology

${ }^{7}$ Cornell University

${ }^{8}$ Columbia University

${ }^{9}$ State University of New York, Binghamton

$$
80-501
$$

U. S. Geological Survey Open File Report

This report is preliminary and has not been edited or reviewed for conforming with Geological Survey standards and nomenclature.

Washington, D. C., 1980 


\section{NOTICE}

The project that is the subject of this report was approved by the Governing Board of the National Research Council, whose members are drawn from the Councils of the National Academy of Sciences, the National Academy of Engineering, and the Institute of Medicine. The members of the Committee responsible for the report were chosen for their special competences and with regard for appropriate balance.

This report has been reviewed by a group other than the authors according to procedures approved by a Report Review Committee consisting of members of the National Academy of Sciences, the National Academy of Engineering, and the Institute of Medicine.

This exchange was supported by a grant from the National Science Foundation. This visit was part of the exchange program operated by the Committee on Scholarly Communication with the People's Republic of China, founded jointly in 1966 by the American Council of Learned Societies, the National Academy of Sciences, and the Social Science Research Council. Sources of funding for the Committee include the National Science Foundation, the International Communications Agency, the Ford Foundation, and the National Endowment for the Humanities.

The Committee represents scholars in the natural, medical, and social sciences, as well as in the humanities. It advises individuals and institutions on means of communicating with their Chinese colleagues, on China's international scholarly activities, and on the state of China's scientific and scholarly pursuits. Members of the Committee are scholars from a broad range of fields, including China studies.

Administrative offices of the Committee are located at the National Academy of Sciences, Washington, D.C.

The views expressed in this report are those of the members of the Plate Tectonics Delegation and are in no way the official views of the Committee on Scholarly Communication with the People's Republic of China or its sponsoring organizations. 


\section{INTRODUCTION}

The American Plate Tectonics Delegation, whose ten members are the authors of this report, visited the People's Republic of China in October 1979 as guests of the Chinese Ministry of Geology. The visit was part of the bilateral exchange program between the U. S. Committee on Scholarly Communication with the People's Republic of China and the Chinese Scientific and Technical Association. Particular scientific importance was attached to visiting the Indus-Tsangbo suture zone in the Tibet Autonomous Region, and the Delegation was honored to be allowed to spend some two weeks in this area; it was among the first foreign scientific groups in recent years to be so honored. The Delegation's activities were centered in Lhasa and Shigatse (Rikaze), and numerous field excursions led by geologists of the Tibet Bureau of Geology afforded a remarkable opportunity to study the suture zone and adjacent rocks over a wide area. In addition to Tibet, the Delegation also visited the region of the Red River fault near Yuanjiang, Yunnan, as well as Chengdu and Beijing.

Inasmuch as so little geological knowledge of the Tibetan area has become known to the outside world, the authors -- with the kind permission of our Chinese colleagues -- have summarized herein some of what has been learned in recent years concerning the geology of this vast and intriguing region, particularly as it is relevant to problems of plate tectonics. We emphasize that the great bulk of the material presented in the following sections is the result of extensive field work in recent years by chinese geologists, and only in some of the interpretations and suggestions for future work are we offering scientific contributions of our own. The Chinese geological field effort in this region is indeed impressive, and the world geological community will be eagerly looking forward to further information in the years to come.

The sections that follow also include tectonic summaries of a number of parts of China adjacent to Tibet, again primarily as related to plate-tectonic problems. As with Tibet, these summaries are based mainly on information provided to us by our hosts and are presented herein with their kind permission.

The Delegation owes a great debt of gratitude to our Chinese colleagues for guiding us to numerous field areas, for the great hospitality that was offered us, and for allowing us to summarize their own scientific findings. We are particularly grateful to Sun Daguan, Director General of the Ministry of Geology, for sponsoring our visit, and to Xiao Xuchang, Bi Kongzhang, and Wang Wei of the Chinese Academy of Geological Sciences for accompanying and guiding us throughout our stay. Others who helped us are far too numerous to mention, but special thanks should be given to geologists Gu Qingge and Zhou Xiang of the Tibet Bureau of Geology and to Duan Xinhua and Zhang Yifei of the Yunnan Bureau of Geology. We are also grateful to the U. S. Committee on Scholarly Communication with the People's Republic of China for organizing and giving financial support to the Delegation.

Al1 of the Delegation members have contributed to the report, but the editor and principal writer has been A. W. Bally. C. R. Allen was Chairman of the Delegation, and F. T. Wu was Vice-Chairman. 


\section{A SKETCH OF THE TECTONICS OF CHINA}

\section{INTRODUCTION}

Recent summaries of the tectonics of China have been provided by Huang Chi-ching (T. K. Huang, 1960a,b,c; Huang et al., 1977, 1978), Institute of Geomechanics (1976), Compilation Group of the Geological Map of China (1976), Compilation Group of the Geological Map of Asia (1976), and Li Chunyü (1975). The excellent new Geologic Map of China (1976) and the interesting Tectonic System Map of the P.R.C. (1976) are particularly useful for an understanding of the tectonics of China.

During our visit Li Chunyü (C. Y. Lee) - one of the elder statesmen of Chinese geology - gave us a comprehensive summary of plate tectonics in China. The following sketch is largely based on that summary and a handout which $\mathrm{Li}$ ( $\mathrm{Li}$ et al., 1979) kindly gave us during our stay in Peking. The map, Figure 1, is a schematic attempt to show the tectonics of China in a broader Central and East Asia context. As a "complete" review cannot easily be given, we will highlight selected aspects at the expense of others which are less familiar to us.

\section{CHINESE TECTONIC THINKING}

To understand the thinking of our Chinese colleagues, one should be aware of the great influence exercised by the late Li Siguang (J. S. Lee) who by many is viewed to be the father of modern Chinese geology and whose writings (1939-1973) are a most important point of departure for anyone interested in Chinese geology. In essence, J. S. Lee noted that the tectonic features of the earth's crust did not form independently of each other. He recognized definite tectonic patterns which he subdivided into three major subcategories, i.e., latitudinal systems, meridional systems, and various shear forms. J. S. Lee and his co-workers explored the geomechanical principles underlying the formation of these structural patterns which are well displayed on the Tectonic System Map of the P.R.C. They also solved a number of elasticity problems to demonstrate the nature of the tectonic stresses and the resulting structure. For instance, in their view, latitudinal structures are due to $\mathrm{N}-\mathrm{S}$ compression arising from the change of rate of the earth's rotation. Some quotations* from the Institute of Geomechanics (1977, pp. 266-268) may help further to elucidate:

*NOTE: Throughout this report we have made minor editorial changes in the quotations from Chinese/English language papers with the intention of improving their readability. We hope we have not inadvertently introduced any changes of meaning. 
"It is demonstrated ... that a tectonic system is a picture of a strain figure imposed in the earth's crust by the dynamic forces acting in a definite manner. It is for this reason that a characteristic type of tectonic system may serve as a reliable basis for tracing the manner of crustal movements. Summarizing the manner of crustal movements as reflected by the above gigantic tectonic systems, we have to admit that the manner of regional movement of the crust and the general movement of the crust as a whole are in unity, i.e., they are either meridional or latitudinal horizontal displacements. In some geological times, meridional horizontal movements tended to push the substances of the upper crust from the higher latitudes toward the lower latitudes, while the latitudinal horizontal movements tended to tear apart the continent or oceanic floor both eastward and westward and compress some parts of the continent into $\mathrm{N}-\mathrm{S}$ fold belts. In other geological times, the substances of the upper crust moved in a reversed direction along the meridians or latitudes.

Such a regular movement of the earth's crust may be accounted for by the change of rate of the earth's rotation....

Therefore, it may be said that the tectonic movement of the earth's crust is an automatic control of the change of rate of the earth's rotation. A speeding up of the earth's rotation will prepare conditions for its speeding up. It appears that it is the change of rate of the earth's rotation that causes the generation and development of tectonic systems.

Every event of crustal movement would bring into existence a series of tectonic systems of different types and sizes. Gigantic tectonic systems, such as latitudinal and meridional structural zones may extend hundreds or even thousands of kilometers. Each gigantic tectonic system often contains many large, medium and small tectonic systems, that is to say, it is composed of tectonic systems of various orders and of different generations. A tectonic system of a higher order, i.e., a small tectonic system is controlled by a medium one, and a medium tectonic system by a large one which is in turn controlled by a gigantic system. And the latter, as a rule, results directly from the latitudinal or meridional horizontal force acting on the upper crust.

The appearance of a certain type of tectonic system, while reflecting the boundary conditions of the area where it was formed, must have necessarily changed the boundary conditions for later tectonic forces in the same area, and must have affected to some extent the adjoining regions. Therefore, when a later crustal movement recurred, except that the original structural features would be strengthened, there would often occur some new tectonic systems of different types and sizes compounded upon the original ones. The compounding of tectonic systems is a necessary result of the continued development of crustal structure. A host of facts suggests that the development of tectonic systems conforms to the common law of the development of all things, i.e., they evolve from a smaller to a larger amount and from the simple to the complex form, and the manner of tectonic movement evolves from a lower phase to a higher phase. Generally speaking, the latitudinal and meridional tectonic systems are the oldest structural types and many of the $\varepsilon$-systems are developed on the foundation of the former, while rotational shear structures are produced only when the earth's crust had experienced repeated tectonic movements and so acquired a complicated texture and structure. 
The establishment of the concept of tectonic systems signifies that we have exceeded phenomenalism in dealing with structural features, setting out to study them from a viewpoint of their mutual connection and continued development. What is more important is that we can apply the regularity of inter-connected geological structures so far recognized to the production practice (mineral exploration) as a guide."

J. S. Lee, who also was the first Minister of Geology of the P.R.C., particularly emphasized the importance of these concepts for ore mineral exploration and earthquake forecasting.

Huang (1960a,b,c,; 1978) and Li (1975, 1979) in their writings focus on the kinematic aspects of Chinese tectonics. Very useful emphas is is given on the evidence for various phases of deformation, as originally conceived by Stille (1924). Huang demonstrated the polyphase genesis of orogenic belts in China. Furthermore, he emphasized particularly the block-like pattern of the Chinese mainland. In this conception, each block is bounded by deep ("depth") fractures, some of which have been active over very long geologic times and some became inactive. Such fractures are classified into translithospheric fractures, lithospheric fractures and crustal fractures (see classification on Table 1).

From these remarks it may be concluded that the geologic tradition of the past thirty years in China was in essence fixistic, and that a widespread mobilism of the type invoked by plate tectonic devotees is a relatively new and unfamiliar concept to Chinese earth scientists; in the late 1960's when American geologists became mobilists, the Chinese geologists were mired in political turmoil. With a refreshingly open-minded attitude, a number of them now explore ways to mesh some of the old insights with the new concepts and to search for evidence in support of plate tectonics in China. The paper by C. Y. Li and his coauthors ( $\mathrm{Li}$ et al., 1979) is a good example. The following description tries to blend some of the views of our Chinese colleagues with some of our own impressions.

In a nutshell, China is the product of the processes which led to gradual accretion onto the Siberian craton of a number of island arc systems and the capturing of relatively small continents. This process continued with the collision of the Indian subcontinent with Asia. The identification of the various building units is basic to an understanding of the geology of Asia.

\section{PRECAMBRIAN PLATFORMS OR CRATONS}

Chinese geologists find it useful to differentiate platforms sensu strictu (or orthoplatforms) from paraplatforms. Huang (1960a,b,c) discussed the differences (see Table 2). In China the following Precambrian cratons (platforms and paraplatforms) are differentiated (see also Figs. 1 and 2). 


\section{The Sino-Korean Paraplatform}

The complex Precambrian history of this unit begins with orogenic events dated radiometrically as far back as $3200-2550 \mathrm{~m} . \mathrm{y}$., the Wutai orogeny (2000 m.y.), and the Chungtiao orogeny (1700 m.y.). The basement formed during these orogenies is covered by Sinian (Late Precambrian), Cambrian, and Ordovician platform deposits. These late Precambrian and lower Paleozoic sequences are separated from the overlying Permo-Carboniferous shallow water and terrestial sequence by a characteristic ubiquitous hiatus spanning from the Silurian to the Devonian. The Mesozoic and Cenozoic are in a continental clastic facies, but Mesozoic volcanics and granitic intrusions are widespread in the eastern platform. Furthermore, a number of Tertiary basalts have been noted.

\section{The Yangtze-Paraplatform (Figs. 1 and 2)}

It is now agreed among Chinese geologists that the basement of this craton consolidated during the Yangtze orogeny (700 m.y.), much later than the Sino-Korean craton. The paraplatform cover consists of marine carbonates and clastics ranging from the late Precambrian (Sinian) to the Triassic. In particular and in contrast to the Sino-Korean Paraplatform, we find a well developed Silurian and Devonian sequence, including some Upper Devonian clastics that appear to be derived from the Cathasian South China fold system which joins the Yangtze craton to the southeast. In parts of Sichuan and the north of Guizhou (Kweichow), the Devonian and Carboniferous are missing. Note also widespread basaltic extrusives of Permian age (Emei Shan volcanics) which are typical for the western portion of the Yangtze Paraplatform.

Jurassic, Cretaceous and Tertiary strata are developed in a continental clastic (often redbed) facies. Some of the boundaries of the Yangtze Paraplatform are formed by very late Mesozoic to Tertiary thrust faults and strike-slip faults (see Fig. 1). The paraplatform is also characterized by an overlying decollement fold system involving the platform cover sediments. The main décollement levels are probably formed by late Precambrian (Sinian) and Triassic evaporites, and by lower Paleozoic shales.

\section{The Tarim Platform}

The Tarim Platform is much less known. Its extent is commonly accepted to coincide with the extent of the Tarim interior basin. No deep wells have penetrated the basement of the Tarim Basin, and its history is inferred from uplifted portions that outcrop along its northern border in the Kelpin and Kuruk Dagh areas. There late Proterozoic sequences with tillites are overlain by fairly complete Paleozoic carbonate sequences. The Mesozoic is dominantly in a clastic facies and generally continental with the exception of marine incursions in Upper Cretaceous and Eocene times. 


\section{SOME PROBLEMS RELATING TO THE DEFINITION OF THE PLATFORMS}

As shown on the map (Fig. 1), all platforms are in general surrounded by Paleozoic or Mesozoic fold systems so that they are fairly well defined. There are, however, some problems.

In the area of the Huaiyang Massif, west of Shanghai, an extension of the Yangtze Paraplatform is shown on most Chinese tectonic maps, and here in a very critical area the nature of the boundary between the Yangtze Paraplatform and the Sino-Korean Platform remains obscure. Whether the Yangtze Paraplatform continues in the Korean Peninsula is debatable; the Siluro-Devonian hiatus so characteristic of the Sino-Korean Platform is also observed in central Korea, suggesting that the Yangtze Paraplatform might terminate under the Yellow Sea and have no equivalent in Korea.

Also, the boundary across the Qinling (Tsinling)-Daba Shan ranges between the Yangtze and the Sino-Korean Paraplatforms is not well described. This boundary zone appears to be a complex fold belt that underwent a number of Paleozoic and Mesozoic deformations in what appears to be a dominantly strikeslip regime.

To the north the separation of the Tarim Platform from the SinoKorean Paraplatform is not well defined. Based on the geology of the surrounding outcrops, it is easily conceivable that the eastern half of the Tarim Basin is underlain by a Paleozoic basement as suggested by the map (Fig. 1). In particular, the Ala Shan region and its northeast panhandle to the north of the Ordos Basin are reported as consolidated by the end of the Proterozoic, but widespread Paleozoic intrusions shown on the Geologic Map of China suggest that this area was later part of a complex Paleozoic fold belt. We may conclude that the Tarim and the Sino-Korean Platforms were certainly welded into one major platform by the end of the Paleozoic, but it is also quite conceivable that the Tarim Platform was part of one continent and the Sino-Korean Platform part of another continent at the beginning and during much of the early Paleozoic. On the other hand, it is also possible that the Tarim Platform and its eastern Ala Shan extension are simply to be viewed as a late Precambrian accretion onto the older Sino-Korean Shield, followed by Paleozoic intrusive overprinting. Detailed paleomagnetic studies may shed some light on these problems.

The basement of the Tsaidam Basin constitutes another problem. A number of Chinese maps imply that this basin may be underlain by a Precambrian platform. No wells are reported to have penetrated into the pre-Mesozoic of that basin. Because the basin is surrounded by complex Caledonian and Variscan folded belts, it may be more plausible that these same fold belts also underlie the basin and that this basin acquired its individuality much later, say during the Mesozoic or more likely yet during the Tertiary. 
Most of the folded belts surrounding the Precambrian platforms are reported to have within them outcrops of Precambrian basement type rocks. As in many other Phanerozoic fold belts of the world, it is still very difficult to document and to unravel the history of such isolated Precambrian outcrops. For instance, Huang's (1978) Hsingkaiides of Northeastern China appear to be such Precambrian basement areas which were thoroughly overprinted by later Paleozoic and Mesozoic intrusions. Precambrian rocks also form significant parts of the Nanshan fold system and its extension in the ranges which separate the Sino-Korean from the Yangtze Paraplatform.

A11 Precambrian areas discussed so far were incorporated into the Asian mainland during Paleozoic and Triassic times. The nature and age of the basement (Paleozoic or Precambrian) underlying the Tibetan Plateau (Regions II and III of map) is not yet adequately known and remains one of the great mysteries of Chinese geology.

To the south, however, we find extensive Precambrian crystalline rocks forming the backbone of the Himalayas. These are part of a complex overthrust slab which has been detached from the Indian craton as a consequence on the collision of the Indian subcontinent with the Asian mainland.

\section{PALEOZOIC FOLD BELTS}

Introduction

The tectonic map of Figure 1 shows that the Baikalian (latest Precambrian), Caledonian (early Paleozoic) and Variscan (late Paleozoic) fold belts accreted progressively to the Siberian Platform. As our interest is focussed on the geology of China and as we are also not particularly well informed to discuss the geology of Siberia and Mongolia, it may be sufficient to mention that only the Baikalian fold belt has an external part with conspicuous foreland folding and thrusting. The remainder of the area to the south of these foreland folds may best be described as an immensely complex system of accreted arc terrains, characterized by widespread polyphase tectonism. The Caledonian areas on the map have been remobilized and intruded by Variscan intrusions, and the Variscan areas often seem to have a Caledonian ancestry.

Also important and frequently overlooked is the great importance of an extensive invasion of Mesozoic batholiths (Fig. 3) into some of the Precambrian areas and into the Paleozoic fold belts.

Finally, we call attention again to the widespread faulting of young Tertiary age which in many places is still active today and which has been interpreted to be the far-reaching effect of the collision of India with Asia (Molnar and Tapponnier, 1975, 1978; Tapponnier and Molnar, 1976, 1977, 1979). 
On the map we singled out some of the more important sutures within Paleozoic fold belts. The position and continuity of these postulated sutures are not well defined, as it is based mainly on the extrapolation of widespread poorly described ophiolites and on occasional descriptions of purported mélange zones. It was therefore particularly welcome that on our visit Li reviewed the evidence for some of the Paleozoic sutures in China which we will mostly quote verbatim. In the Paleozoic folded belts to the north of the Tarim and the Sino-Korean Platform, a northern Dzungarian fold system to the north of the basin of the same name is differentiated from the more southerly Tian Shan Inner Mongolian - Kinghan fold system. The Paleozoic sutures are described by Li et al. (1979) as follows:

The West Zhunger (Dzungarina) Sub-belt (No. 1 on Fig. 2) outcrops discontinuously in an east-northeastern direction from the northern bank of Aibi Lake to the Baiyang River for a length of about $200 \mathrm{~km}$. The suture was formed in Middle Ordovician and the Middle and Upper Silurian, which is fossiliferous and unconformably overlapped by Devonian or Carboniferous strata. The Ordovician system consists of various submarine basic-intermediate volcanics, pyroclastics and siliceous rocks that are more than $4000 \mathrm{~m}$ thick. The Middle and Upper Silurian has a thickness of more than $8000 \mathrm{~m}$ of spilites, amygdaloidal basalt, graywacke, jasper, and siliceous rocks. Ultrabasic to basic rocks are mostly lenticular or banded and emplaced in basic lavas or pyroclastics dipping $60^{\circ}-80^{\circ}$ to the northwest. Such rocks include dunite, harzburgite, enstenite, peridotite, serpentinite, and some gabbro. Conglomerates of Middle Devonian, Lower Carboniferous and Lower Permian in this region yield pebbles of ultrabasic-basic rocks.

(Note that the West Zhunger Belt coincides with the Darbut Paleozoic lithospheric fracture zone of Huang, 1978.)

The Armatai Sub-belt (No. 2 on Fig. 2) outcrops along the northern piedmont of Beitashan, strikes in a northeastern direction and stretches discontinuously for a distance of about $240 \mathrm{~km}$. The ophiolite suite is found in the Beitashan formation and the Asushan formation of Lower and Middle Devonian. These are overlapped unconformably by Upper Devonian or Middle Carboniferous strata. The Asushan formation consists of submarine basic-intermediate volcanics and sedimentary rocks which include amygdaloidal basalt, pyroxene andesite, pyroclastics, siliceous rocks and lenticular limestones, about $2000 \mathrm{~m}$ thick and containing trilobites, corals, brachiopods, gastropods and cephalopods. The Beitashan formation exceeds $1400 \mathrm{~km}$ and varies in lithology including amygdaloidal basalt, basic tuff and volcanic breccia, pyroxene andesite, jasper and limestone lenses. The banded and lenticular ultrabasic-basic rocks are emplaced in pyroclastics. In the main they are harzburgite and some dunite and lherzolite (Diallage bronzite peridotite).

Huang, 1978.)

(This zone is called the Paleozoic Irtish lithospheric fracture by 
The Kelameili Sub-belt (No. 3 on Fig. 2) stretches northwestward from Takezhale Mountains to the eastern margin of Zhunger Basin for about $250 \mathrm{~km}$. Ultrabasic rocks are in the main within the Middle Devonian and the Lower Carboniferous. Most of the ultrabasic rock bodies outcrop on the hanging wall of a deep fracture which is juxtaposed along the southwestern side of the sub-belt and dips steeply toward the east-northeast. Middle Carboniferous strata overlap the ultrabasic rocks.

The Suelun Mts.-Hegen Mts. Ophiolite Belt in Inner Mongolia or the Silamulun Paleozoic lithospheric fracture of Huang (1978) (No. 4 on Fig. 2) is about $1200 \mathrm{~km}$ long and extends fron northern Bayanzhuor through Erlianhuote and Sunitezuoqi to west Wuzhumuxin. The ophiolite suite is composed of schistose basalt, tholeiite, spilite, andesite basalt, siliceous rock and jasper of Middle Devonian, Middle Carboniferous and Lower Permian age. These ages are supported by fossil determinations. In the northern part of Inner Mongolia, ultra-basic rocks are emplaced in strata of the three above-mentioned periods or in neighboring strata. The ophiolite suites appear to become progressively younger proceeding from north to south.

It should be pointed out that actually the Zhunger Ophiolite Belts (Nos. 1 and 2 on Fig. 2) must be connected with the Suelun Mountains-Hegen Mountains Ophiolite Belt, because a contemporaneous and similar ophiolite suite has been found in Gobi-Altai and Gobi-Tianshan in the southern part of the Mongolian People's Republic.

(Note also that the suture zones so far described connect well with the ones described by Zonenshain, 1972, and may even be followed into the basement of the West Siberian Basin as suggested by the map of Kontorovich et a1., 1975).

The Tianshan Ophiolite Belt can be subdivided into the South Tianshan Sub-belt and the North Tianshan Sub-belt (No. 5 of Fig. 2) is about $1200 \mathrm{~km}$ long from Jinghe to Hongshishan. Ophiolite suites are found respectively in Lower and Middle Ordovician, in Middle and Upper Silurian, in Lower and Middle Devonian and in Lower Carboniferous. Generally, they are composed of basic pillow lava, siliceous rocks and ultrabasic-basic complexes.

The South Tianshan Sub-belt (No. 6 on Fig. 2) is located along the south side of the Harketawu Mountains and may be followed through Kumishi to Liuyuan and Jinta in Gansu Province. Ophiolite suites are found in Lower and Middle Ordovician, in Middle and Upper Silurian, in Middle Devonian and in Permian sequences. Most of the strata were slightly metamorphosed except for the Ordovician which generally is in green schist facies and partly in amphibolite facies. The main components of the ophiolite suite are basic volcanics, siliceous rock, graywacke and ultrabasic-basic igneous rock. Glaucophane schists have been discovered in Upper Silurian strata to the north of the northern slope of the Harketawu Mountains at the upper reaches of the Kekesu River.

(The tectonic setting of the western continuation of the S. Tian Shan suture in Russia is particularly well described by Burtman, 1975.) 
The Yinshan-Tumen Ophiolite Belt (No. 7 on Fig. 2) stretches discontinuously from the northern piedmonts of Langshan and Yinshan eastward through Wendurmiao and Kesheketeng to Huadian and Tumen of Jilin Province for a length of about $1800 \mathrm{~km}$. The country rocks of the ophiolite suite are lower Paleozoic in Inner Mongolia and Devono-Silurian in Jilin Province. The lower Paleozoic of Inner Mongolia and Devono-Silurian of Jilin Province are generally crystalline schists and unfossiliferous. Ultrabasic to basic rock bodies outcrop in green schist. Isotopic ages of several ultrabasic to basic rock bodies in Jilin Province are 350-331 m.y. In recent years, glaucophane schist has been discovered in the Harhada Formation of the Wendurmiao Group of Inner Mongolia. Carboniferous and Permian rocks containing ophiolite suites occur both in Inner Mongolia and in Kilin Province. An outstanding deep fracture belt about $1500 \mathrm{~km}$ long and more than $10 \mathrm{~km}$ wide stretches from west to east along the northern margin of Inner Mongolian Axis. It coincides with the Yinshan-Tumen Ophiolite Belt. The ages of ophiolite suites along the northern piedmont of Yinshan tend to become younger from south to north just opposite to those of the Suelun Mountains-Hegen Mountains Ophiolite Belt. Furthermore, glaucophane schists have been discovered at many places in the Wendurmiao region of Inner Mongolia in recent years and mélange occurs in the Moruogeqin formation of the same region. Based on these data of the distribution of ophiolite belts and on the ages of folded belts in which they were emplaced and considering various polarity indicators of the subduction zone, we have a preliminary knowledge about the Paleo-plate tectonics to the north of the Tarim (Talimu) and SinoKorean Massifs as follows:

A northward subduction along the southern side of the Altai Mountains occurred during the early Paleozoic, so that the Ordovician and Silurian along the crest of the Altai Mountains were metamorphosed to form various low $P / T$ indicative minerals such as andalusite, sillimanite, staurolite and cordierite in association with widespread acid to intermediate magmatism.

During the late Paleozoic the second subduction zone became active along the long arcuate belt from Kelameili through the Balikun Mountains of Xinkiang to the Suelun and Hegen Mountains of Inner Mongolia. To the north of the above line and in the territory of the Mongolian People's Republic, a wide belt of the contemporaneous acid to intermediate volcanics and granite was emplace. Obviously, Altai, West Zhunger, East Zhunger, the Suelun and Hegen Mountains and the Xingan Range belong to the epicontinental mountain ranges of Siberia Massif. In contrast to the Altai and Xingan Range, the mountain ranges of Tian Shan, Beishan, Yinshan and Tumen region should belong to the epicontinental cordillera of the Tarim (Talimu) Sino-Korean Massif. Paleogeographically, the North Tian Shan corresponds to an oceanic basin during the Paleozoic while South Tian Shan was a marginal sea along the northern border of the Talimu Massif (see also Burtman, 1975).

An initial conclusion can be drawn that there had been two subduction zones with opposite polarity in this region. The northern subduction zone became active in the early Paleozoic and ceased before the Middle Carboniferous 
along the northern side of North Tian Shan of Xinjiang and Beishan of Gansu Province. The activity of the southern subduction zone from Hantenggeli Peak of South Tian Shan to Arensegentuohai was limited to the late Paleozoic.

The southward subduction zone of North Tian Shan stretches eastward along the northern piedmont of Yinshan to Yanji region of Jilin Province. As the paleo-ocean crust was subducted toward both the north and the south, the late Paleozoic oceanic basin diminished gradually from west to east. Finally in the Late Permian, the two epicontinental mountain ranges along the Sino-Korean Massif and along the Siberian Massif collided along the line from the Suelun Mountains through the Hegan Mountains to the Xilamulun River. This suture is precisely the line separating the Cathysian Phytogeographic Region in the south from the Angaraian Phytogeographic Region to the north.

After the formation of paleo-Asia, the eastern parts of Heilonjiang Province and Jilin Province were still oceanic basins during the Permian and early Mesozoic. Subduction toward the west-northwest happened in the middle Mesozoic approximately along the Wusuli River. The rather wide belt of calc-alkaline igneous rocks formed in northeast China and the deep focus earthquakes in the eastern parts of Heilongjiang and Jilin are thought to be associated with that subduction phase. It is, in fact, within the Circum-Pacific Tectonic Domain.

To the south of the Tarim and the Sino-Korean Platform we encounter another Paleozoic fold belt: the Qilian-Qinling (Tsingling) and the QinchaiQinling (Tsinling) systems. The structure of these systems has been profoundly modified by Tertiary deformation which appears to be dominated by strike-slip faults. For the evidence of Paleozoic suturing, we again follow the descriptions provided by $L i$ and his colleagues (1979):

"There had been an extensive ocean to the south of the Tarim (Talimu) Sino-Korean Massif. Between the ocean and the massif, we find the so-called Hexi Corridor Transition Belt which was a miogeosyncline. South of this corridor is the North Qilian eugeosyncline where more than 20,000 m of Sinian and early Paleozoic strata are mostly clastics, crystalloclastic tuff, crystalline limestone, phyllite and flysch sandstone. There also was a discontinuous belt of uplifts in the Central Qilian. Various kinds of Precambrian crystalline schist outcropped as a microcontinent or median massif within the geosyncline. Another geosynclinal sedimentary basin existed in South Qilian at the same time. A well-developed ophiolite suite (the Qilian-Qinling Paleozoic subduction zone - No. 8 on Fig. 2) which consists of gabbro, diabase, radiolarian chert, flysch, submarine basic-intermediate and acid-intermediate volcanics and various ultrabasic igneous rocks was found in the Sinian, Cambrian and Ordovician of the North Qilian Mountains. Ophiolite can also be found in the eastern section of South Qilian where ultrabasic rocks are emplaced in Cambrian and Ordovician strata. The Qilian geosyncline stretched eastward through Baoji and connected with the narrow belt composed of Cambrian and Ordovician strata of the North Qinling Piedmont Fracture Belt. A series of ultrabasic to basic rock bodies constitute a discontinuous ophiolite belt from Gansu Province through Shanxi Province to Xinyang of Henan Province. Country rocks of the 
ophiolite belt are Proterozoic, Sinian, and Carboniferous in age. High P/T metamorphism was demonstrated by studies of Phengite of $3 \mathrm{~T}$ type and eclogite of the C-group found in the metamorphic rocks near Xinyang.

The Tarim (Talimu) Sino-Korean Massif connected the Qilian Geosynclinal Folded Belt with a deep fracture which was formerly a subduction zone between the two tectonic units. In the early Paleozoic, geosynclinal formations were folded during the so-called early Caledonian orogeny. Unconformities can be found in some localities. Thereafter, the geosyncline shifted successively to the north until the end of the Silurian when all the geosynclinal sediments were folded and underthrust northward beneath the massif on the north. Another deep fracture is recognized between North Qilian and Central Qilian. Part of the geosynclinal formations of North Qilian was subducted to the south. As a result, a high $\mathrm{P} / \mathrm{T}$ metamorphic belt of well-developed glaucophane schist as seen in Qilian County and eclogite found in other places extends more than $10 \mathrm{~km}$ in length. The Qilian Mountains were diagonally truncated at the western end by the Arjin deep fracture or the Arjin late Paleozoic subduction zone for transform fault (No. 10 on Fig. 2). The fracture is thought to be a transform fault which accompanied the shift of the geosyncline toward the north contemporaneous with the successive folding of the geosyncline.

The West Kunlun Mountains (No. 11 on Fig. 2) along the southern margin of the Tarim (Talimu) Massif stretched southeastward into the Arjin Qimantage, and Burhanbuda Mountains to the south of the Chaidamu (Tsaidam) Basin and northeastward into the Zhongwunong and Oulongbuluke Mountains to the north of the Chaidamu (Tsaidam) Basin. All these regions were part of a eugeosyncline during the Paleozoic and were transformed into a late Paleozoic folded belt. In the West Kunlun Mountains, submarine basalt, spilite and diabase porphyry were included in the Ordovician while basalt, hornblende-andesite porphyry, diorite porphyry and diabase porphyry are of Middle Devonian and Lower Carboniferous age. Ultrabasic to basic rocks are emplaced into the Sinian pyroclastics and Cambrian, Ordovician and Carboniferous strata. Along the Argin Mountains (Altyn Tagh), more than 70 ultrabasic to basic rock bodies, large and smal1, are emplaced into Sinian and Paleozoic rock for more than $700 \mathrm{~km}$ from Qiemo to Annaba. A deep fracture about $600 \mathrm{~km}$ long marked by more than 100 ultrabasic to basic rock bodies in Sinian (upper Precambrian) and lower Paleozoic strata occurs along the northern margin of Chaidamu (Tsaidam) Median Massif east of Annanba. These igneous rocks and volcanics are thought to represent a dismembered ophiolite suite although further studies are required to confirm this speculation.

The Chaidamu (Tsaidam) Basin is filled for the most part by Tertiary and locally by Cretaceous sediments. Many drill holes, some of them more than $3000 \mathrm{~m}$ deep, have so far not penetrated below the Tertiary. It may be deduced that most of the basement of the Chaidamu Basin, at least in the middle, is a Precambrian stable continental block which did not suffer intensive folding since that time.

During the late Paleozoic, folding occurred many times due to northward compression. Unconformities have been found between the Devono-Silurian 
and the Carboniferous and between the Carboniferous and the Permian. The geosyncline on the southern margin of the Talimu Massif was subducted northward beneath the massif. Three unconformities are seen between the Upper Devonian and Lower Carboniferous, between the Lower and Middle Carboniferous and between the Upper Permian and Lower Triassic. Along the Burhanbuda deep fracture of today, oceanic crust of a geosyncline was subducted northward beneath the Chaidamu (Tsaidam) Median Massif. The late Paleozoic fold belt stretched eastward into Qinling and gradually narrowed and disappeared. Accompanying the subduction and folding of the geosyncline, there was transcurrent faulting along the Arjin Mountains. As a result, the southeastern block of the fault was pushed northeastward and the southwestern section of the Arjin Mountains was formed."

\section{The Caledonides of the South China Fold System}

This unit lies to the south and adjacent to the Yangtze Paraplatform. While all previously described fold systems can be viewed as the product of Paleozoic accretions to the Siberian Platform the South China or Cathasian fold system was probably formed on the margins of the Yangtze Paraplatform at a time when that area formed a continent that was isolated from the Asian mainland.

In the main, the South China fold belt was formed in mid-Paleozoic time. The Upper Devonian clastics of the Yangtze Platform may in this conception be viewed as the foreland clastic wedge or foredeep associated with that fold belt. Widespread acid to intermediate granitic intrusions and extrusions in this province suggest a subduction zone to the southeast, which now is buried under the South China Sea shelf.

According to Huang (1978) the coastal regions of this province (i.e., Zhejiang, Fujian, Guangdong, and the adjacent continental shelf, as well as the island of Hainan) were further deformed in Variscan times. Furthermore and later, this province has also been invaded by Jurassic and Cretaceous intrusions and their associated volcanics, providing for an active and complex tectonic history extending well beyond the primary Caledonian consolidation of these provinces.

The Indosinian Qinling-Songban-Ganzi Fold Belt

According to Huang (1960), the concept of an Indosinian orogeny was introduced by French and Chinese geologists to include various phases of Triassic deformation. Figure 1 shows that Indosinian deformation is prominent in a band located to the south of the Kunlun-Qinling (Tsinling) fold system, the SongbanGanzi fold belt and to the west of the Kekexili-Jinsha-Ailao suture, the Sanjiang fold system of Huang (1978). Of course, Indosinian folding is also prominent in Indochina. Not indicated on the map is rather widespread deformation reported by Huang $(1960 a, b)$ straddling the boundary between the Yangtze Paraplatform and the Cathasian fold belt to the south, i.e., in the provinces of Guangxi, Hunan, and Jiangsi. Let us now again follow the description of Indosinian sutures and subduction zones given by $L i$ et a1. (1979): 
"After the Paleozoic, all the geosynclines in Qilian, North Qinling and to the north and south of the Chaidamu Median Massif were folded and uplifted to form mountain ranges which joined with the Talimu-Sino-Korean Massif. But a newly born geosyncline was set up to the south of the accreted massif and a large-scale transgression occurred. In the western part of that geosyncline, a marine sedimentary basin branched off with an arm stretching northwestward between South Qilian and the mountain range along the northern margin of the Chaidamu Median Massif. Triassic clastics and carbonates accumulated in this geosyncline. Triassic sediments are more than $11,000 \mathrm{~m}$ thick in the Bayankala Mountains and thinning eastward in the Qinling Mountains.

A great fracture more than $1,300 \mathrm{~km}$ in length extended along the southern margin of Qinghai Lake through the northern piedmont of the Qinling Mountains to Nanyang of Henan Province. (This fracture closely parallels the Qinghai-Qinling early Paleozoic subduction zone [No. 9 of Fig. 2] and its eastern continuation. It is also the lithospheric fracture: northern margin of Tsaidam - southern margin of North Qinling - North Huaiyang described by Huang, 1978). Geosynclinal formations underwent folding after the Middle Triassic when they were subducted to the north beneath the Caledonides in Qinlian. Along the western section of the subduction zone, well-developed mélange was composed of exotic blocks of Permo-Carboniferous 1imestone mingled with Triassic shale and slate. Exotic blocks vary from fist size up to more than one kilometer in diameter. Sometimes we could find that strata of Devonian age were intermingled with those of Carboniferous age. In the eastern section of the fracture along the boundary between Shanxi and Henan Province, blue schist is found in country rocks which are basic volcanics, metaclastics and diabase of Sinian age and basic volcanics, etc., of Silurian age. The main indicative mineral is crossite and glaucophane is subordinate. The blue schist may be regarded as a fragment of a high $\mathrm{P} / \mathrm{T}$ metamorphic belt.

More than 100 ultrabasic to basic rock bodies have been found in Permian, Carboniferous or Devonian, along the east Kunlun fracture (No. 11 on Fig. 2) on the southern piedmont of the Burhanbuda Mountains and its eastern elongation from the Jishi Mountains (Amneh-ma-chin Mts.) through Maqin and Maqu to Lueyang of the Shanxi Province. In this belt huge exotic blocks of Permian limestone occur within Triassic slate and sandstone, or fossiliferous exotic blocks of Lower Permian age occur within the Upper Permian. We hold that they mark a mélange belt. Based on these data, this fracture seems to have been a subduction zone which reactivated the South Piedmont subduction zone of the Burhanbuda Mountains of late Paleozoic age."

These descriptions suggest that Indosinian subduction processes are superposed on or intersect the preceding Variscan subduction zones described from the same area. A more precise description of the relative importance of Indosinian versus Variscan deformation and their manifestations is therefore particularly desirable for the Kunlun-Qinling (Tsinling) fold systems.

Kekexili-Jinsha-Ailao Subduction Zone

Moving toward the southwest margin of the Indosinian fold belt, we again follow $L i$ et al. (1979): 
"The Qinghai-Xizang-West Yunan Tectonic District belongs to the Tethyan tectonic domain and is located in the southwestern part of China. In this region, there are three important subduction zones and sutures which are delineated from northeast to southwest in the following:

The Kekexili-Jinsha-Ailao subduction zone is one of the most important subduction zones of the Tethys undulating along the northern part and the eastern margin of the Qinghai-Xizang Plateau. Its western section stretches along the Jinsha River and its upstream continuation into the northern piedmont of the Kekexili Mountains forming a gentle arc convex toward the northeast while the eastern section continues approximately straight up to the southwest of the Ailao Mountains. A concavo-convex shifting of the subduction zone can be recognized along the Kalakunlun Mountains and to the east of it. The tortuous pattern of the subduction zone is thought to be an effect of later structural remolding rather than an original feature. Subduction activity started during the Late Permian and faded away in the Late Triassic. However, splitoff continental blocks before and/or when the subduction activity was proceeding gave rise to micro-continents in the midst of the Three-River geosynclinal folded belt and even in northern Xizang. One such micro-continent is in the Batang-Derong district of Sichuan Province where the Cambrian to Lower Permian strata are characterized by stable sedimentary facies, plentiful fossils and lack of metamorphism. It is reasonable to attribute this block to a segment of the Yanzi (Yangtze) Massif to the east.

A series of small ultrabasic to basic rock bodies outcrop along the Jinsha River and its upper reach, the Tongtian (Tung Tien) River, but the majority of them appear to be ophiolitic mélange rather than ophiolite suites in their original sequence. The intensively sheared, crushed and of ten serpentinized ultrabasic to basic rocks which had been the original components of ophiolite suites wrapped fresh gabbro, rodingite, omphacite-eclogite, chromite and limestone containing Silurian to Early Permian fossils of various sorts. Together with the ophiolite mélange which occurs mostly on the underthrusting plate, another kind of mélange was distributed along the opposite eastern and overthrust plate. It consists of an arenaceous and argillaceous matrix with flysch or flyschoid features and various exotic blocks. All the fossils are found in the exotic blocks, such as corals, brachiopods, trilobite, fusulinids, etc., of Devonian, Carboniferous and Permian age. These are without exception older than those in the matrix which is proved by lamellibrachiatas to be Late Triassic for the most part. This kind of mélange can be mapped as one of the stratigraphic units of the Triassic.

Some minerals indicative of high $\mathrm{P} / \mathrm{T}$, such as stilpnomelane, pumpellyite, and jadeite, have been found associated with the ophiolitic mélange. In addition, an analysis of the paragenesis of metamorphic minerals in green schist facies rocks reveals that the tectonic stress increased during regional metamorphism toward the subduction zone coming from the east on the overthrust plate.

At the same time an ancient volcanic island arc was situated to the east of the subduction zone in the area from Yushu to Muli where various tholeitic and calc-alkaline volcanics are widely distributed. There appears to 
be a general tendency of increasing potash and alkalies toward the east and away from the subduction zone. A giant belt of acid intrusions with associated low $\mathrm{P} / \mathrm{T}$ metamorphism was distributed mainly along the eastern margin of the island arc from the Qiaor Mountains to Daocheng.

Many small intrusions of ultrabasic to basic rock delineate the island-arc on its eastern margin to mark a deep fracture there. They are mainly composed of clino-augite peridotite and hornblende-clino-augite peridotite with subordinate picrite. Petrochemically, they are ferro-ultrabasic rocks. One kind of mélange composed of exotic blocks with Silurian to Early Permian fossils such as cephalopods, brachiopods, fusulinids, coral, etc., and a Triassic matrix of sandstone and slate has been found from Yushu to Ganzi. Probably ophiolitic mélange might exist in the latter locality.

A great thickness of Triassic flysch and flyschoid rocks (i.e., the so-called Xikang Group and Bayankalashan Group) that accumulated to the north and the east of the above-mentioned volcanic island-arc manifest a geosyncline of the Japan Sea type. Probably, a complete trench, arc and back-arc basin system existed in the region from the Jinsha River to the Longmen Mountains during the Triassic period.

There are more than 300 ultrabasic to basic rock bodies found in the Diancang Mountains and Ailao Mountains to the south of the sharp meander of the Kinshan River for a distance of more than $800 \mathrm{~km}$. Generally speaking, these belong to ophiolite suites, but some of them lack the common sequence of ophiolite suites in addition to the occurrence of a few picrites. Instead, many exotic blocks of slightly metamorphosed rock, fossiliferous Triassic sandstone, and rather fresh ultrabasic rock appear to be wrapped in a few ultrabasic to basic complexes. They probably represent ophiolitic mélanges. It is reported that glaucophane has been discovered at Xiaqiaotou near Zhongdian, pumpellyite in Lijiang and along the eastern bank of Er Lake to the region near Midu, as well as uralite-albite-chlorite schist in slightly metamorphosed rocks of the Ailao Mountains near Xinping. Acid intrusions dating 217-91 m.y. are relatively widespread in the southern section of the Ailao Mountains. The associated low $\mathrm{P} / \mathrm{T}$ index minerals are cordierite, sillimanite, staurolite, and andalusite. The Red River deep fracture to the northeast of the Ailao Mountains metamorphics appears to be an active transcurrent fault, but opinions about the slip direction of the two blocks remain controversial."

\section{The Sanjiang Fold System}

South and west of the Kekexili-Jinsha-Ailao Shan suture is the Sanjiang fold system. On our map on Figures 1 and 2, we separate the Tibetan Subregion III, from Region III and follow Huang (1977) to include this area in the Sanjiang fold system. The summary of the stratigraphy of the Lanping Simao fold belt, given by Duan Xinhua and Zhao Hong (1979) of the Geology Bureau for Yunnan Province (Fig. 14) fairly well summarizes the characteristics of this zone and a comparison with the stratigraphic summary of Region III (Table 1) shows a number of striking similarities between the two regions. 
Although Huang (1978) emphasizes the polycyclic nature of the Sanjiang fold belt, Paleozoic deformations do not appear as obvious on the stratigraphic summaries. As Figure 1 illustrates, the Sanjiang fold system finds its continuation into the folded belts of Indochina. It will, however, be noted that we excluded the Shan Plateau and the Dehong Shan-Kachin area (west of the Nujiang [Salween] River) because Indosinian folding there is not readily apparent.

\section{A SHORT DISCUSSION REGARDING THE LATE PALEOZOIC-TRIASSIC PALEOTETHYS}

Recently a number of authors have drawn attention to the existence of a late Paleozoic-Triassic "Paleotethys" (e.g., de Lapparent et al., 1970; Stöckl in, 1977; and Sengör, 1979). It its essence, the Paleotethys is the wedge- 7 ike ocean between Laurasia (tne Northern Doma in of Stöckl in, 1977) and Gondwanaland as it appears on various Permo-Triassic reconstructions. During the late Paleozoic, the northern margin of the Paleotethys presumably was an active margin. The nature of its southern margin is not that clear, but it appears to be more like a passive margin of some sorts. The Permo-Triassic Tethys closed by the end of Triassic time, during an early Kimmerian (Indosinian) orogeny. That orogeny terminated with the collision of a single long, narrow continent or more likely a group of small continents with Asia. These continents constitute the Central Doma in of Stöckl in (1977) in the area of Iran and Central Asia. Sengör (1979) has traced this continental domain farther west across Turkey and into eastern Europe and refers to it as the Kimmerian continent which he also extends toward the east to include parts of the Tibetan Plateau. The concept postulates that as the Paleotethys closes to the north of the Central Domain, a Neotethys of Jurassic-Cretaceous age opens to the south in the wake of the generally northward drifting continental masses that constitute the Central Domain (or the Kimmerian continent).

According to Stöcklin (1977) the northern boundary of the Paleotethys, that is the boundary between his Northern Domain and his Central Domain, is well determined. He defines the Northern Domain as "that part of the IranianCentral Asian system in which Alpine (Tertiary) orogenic processes were superimposed not on a Paleozoic continental platform and its recognizable platform as in the Southern and Central Domains, but on a 'Hercynian' basement, or on a platform area that is widely known under the designation of 'epi-Hercynian' platform." Stöckl in adds a proviso that "Hercynian" in this case would not include any early Kimmerian (Triassic) structural events, as these occur both in the Northern and in the Central Domain.

In the Northern Domain, intensive early Kimmerian (the Late Triassic) folding and granitization is superimposed on the Hercynian basement, followed by more localized late Kimmerian (Jurassic-Cretaceous) folding. In contrast, in the Central Domain, early Kimmerian tectonics are characterized by horst and graben structures and sharp facies changes from shelf carbonates into clastics. These early Kimmerian horst and graben structures are interpreted to be related to the detachment of the Central Domain from the southern Gondwana Platform. 
Based on these criteria Stöcklin (1977) traces the boundary between his Central and Southern Domains along the Herat-Hindukush-Wanch-Akbaytal fault system. To the east in China, one is first tempted to extend that boundary between the Paleozoic Kunlun fold system and the Indosinian Songban-Ganzi fold system. However, that fold system as well as its southwestern neighbor, the Sanjiang fold system, does not appear to have an equivalent in the Middle East. It, therefore, may be more sensible to postulate that the above described boundary bifurcates east of the Pamir Mountains to form the boundaries which contain the Indosinian fold systems of China and Indochina. These would then represent accreted Permo-Triassic island arc terrains which formed at the northwest margin of the Paleotethys. Possible older continental fragments probably would have affinities to the Yangtze Platform, but a precise definition and search for the origin of such fragments would depend on more detailed mapping combined with extensive paleomagnetic studies.

\section{THE TIBETAN PLATEAU*}

As described in our notes on the Tibetan Plateau, the plateau is not a single tectonic unit. A northern and eastern strip is underlain by the Indosinian fold belts which have already been described. To the south of this unit, we differentiate a Central Tibetan Plateau to the north from a Southern Plateau to the south. The two are separated from each other by the Banggong Hu-Dongqiao-Nujiang fracture zone.

\section{The Central Tibetan Plateau (Region III minus Subregion III )}

This region corresponds to the Region III of our notes on Tibet, but note that Subregion III, has been separated from the two western subregions and included in the Sanjiang fold system.

The basic stratigraphy of Subregions $\mathrm{III}_{2}$ and $\mathrm{III}_{3}$ is shown on Tables 5 and 6 and described in our Notes on Tibetän Geology.

The age of the basement of the Central Tibetan region is not known and could be either Precambrian or Paleozoic. The Paleozoic and Triassic appear in a marine platform facies. An unconformity at the base of the Jurassic in $\mathrm{III}_{3}$ suggests an early Kimmerian event, and another unconformity at the base of the Lower Cretaceous ( in $\mathrm{III}_{2}$ ) suggests a late Kimmerian event. All in

\footnotetext{
*Morphologically, the Tibetan Plateau is the high and mountainous area located between the Tarim and Tsaidam Basins to the north and the Indus-Ganges Plains to the south. Because the Kunlun to the north and the Himalayan Ranges to the south form distinctly separate geologic units, it is preferable to limit the term Tibetan Plateau to the areabetween the south slope of the Kunlun and the Indus-Yaluzanbu suture. See also footnote on p. 2 of Notes on Tibetan Geology.
} 
all, it is reasonable to include this zone as part of the Central Domain differentiated by Stöcklin (1977) or the eastern extension of the Kimmerian continent postulated by Sengör (1979). Region $\mathrm{III}_{3}$ coincides in part with the areas characterized by Carboniferous tillites as described by Norin (1946). Thus a Gondwana origin is suggested for this block. The black slate zone which has been traced by Norin (1979) into Region $\mathrm{III}_{3}$ may well be represented by the Paleozoic slates and shales noted in Table 2.

To further reinforce our generic correlation with Stöcklin's Central Domain, we note that intrusives ranging from $99 \mathrm{~m} . \mathrm{y}$. to $200 \mathrm{~m} . \mathrm{y}$. are reported from the southern part of Region III (see Notes on Tibet, p. 44). These appear equivalent to similar intrusives reported by Stöckl in in his IranCentral Asia synthesis. Last not but least, as in the Central Domain, Tertiary and Quaternary volcanism seem to be widespread in Region III $_{2}$ and III 3 , as also noted by Gansser (1977), Burke et al. (1974) and Norin (1979 and earlier). To the east, the Central Tibetan Plateau wedges out and in the Three Rivers (Sanjiang) area, no equivalent can be defined so far.

However, in a highly speculative vein, one could visualize the Western Shan Plateau and its continuation into China (the Dehong Shan-Kachin area, to the west of the Nujiang [Salween] River) to be an equivalent of the Central Plateau. There, as in Norin's area, fluvioglacial deposits of Carboniferous age have been reported and suggest a link with Gondwana (Hou et al., 1979). Thus, what little we know about the stratigraphy of that area appears compatible with such a correlation and a strike-slip offset in the order of $1000 \mathrm{~km}$ is quite compatible with large amounts of Tertiary shortening postulated by some authors (Molnar and Tapponnier, 1975) as a consequence of the India-Eurasia collision.

The Dehong Shan-Kachin area is referred to by Li et al. (1979) as the Baoshan-Menglian Region, and we quote some of this author's comments regarding this area:

"It seems that a continental block exists between the Lancang and $\mathrm{Nu}$ River in west Yunan. The block is, in fact, a corner of the Shan State Median Massif protruding to the north. The complete and relatively thick strata in the Baoshan-Menglian region are nothing but the cover on basement of the median massif consolidated before the Cambrian. The newly reported discovery of pumpellyite in Lancang metamorphics and of glaucophane schist in the Lancang metamorphics to the east of Lancang County and the existence of a great granite belt along the western bank of the Lancang River dating 217-197 m.y. might be considered as indicators of a westward subduction zone along the eastern margin of the median massif. The paradoxical geosynclinal Triassic strata and the phenomenon of the Triassic grading into epicontinental Lower Jurassic make it clear that the geosyncline in the Lanping-Simao region probably developed in a closed marginal sea with sialic crust rather than in an open ocean." 
Of some interest is the suggestion of westward subduction of an ocean under the Shan Plateau. Such a westward subduction had been postulated by workers in Malaysia for the lower Paleozoic with a shifting of the subduction zone to the east in upper Paleozoic Triassic times (Hutchinson, 1973). This would in a very gross approximation track with the observations we just quoted, and of course, the question then remains whether by analogy one should consider subduction towards the south beneath the Central Tibetan Plateau (see also Sengör, 1979).

The Banggong Hu-Dongqiao-Nujiang Zone

This zone is described in some detail in our Notes on Tibetan Geology, pp. 43-44. In its essence, it appears to be a suture zone which has welded the South Tibetan Plateau to the North Tibetan Plateau during the Early Cretaceous. The ocean which was eliminated is represented by ophiolite outcrops and may well have formed during Jurassic times. The suturing process is accompanied by granitic intrusions that range in age from $200 \mathrm{~m} . \mathrm{y}$. to $99 \mathrm{~m} . \mathrm{y}$.

By Late Cretaceous time, the southern and central parts of the Tibetan Plateau were welded together to form the southernmost border of Eurasia.

The Southern Tibetan Plateau (the Nianqing Tanggula Block, Region II)

This region is also discussed in some detail on pp. 41-42 of our Notes on Tibetan Geology, and the basic stratigraphy is shown on Figures 6 and 7. Again, we have not much of a feeling for the age of the basement, which may be either Precambrian or lower Paleozoic. The Paleozoic sequence is in a marine carbonate-clastic facies. The Triassic to Jurassic gives the impression of a shallow water marine platform facies. To the north, however, thick "geosynclinal" sequences of Jurassic to Lower Cretaceous age are reported. The Lower Cretaceous occurs in the form of volcanics.

The southern third of the southern Tibetan Platform (Subregion $I_{1}$ ) is dominated by widespread Cretaceous to Paleocene granitic intrusions and the associated volcanics. The latter are in profound angular unconformity with underlying rocks. It is concluded that this subregion represents a volcanic island arc. Note that if we are to believe the tentative paleomagnetic determination from the Ladakh intrusives near Kargil (Klootwijk, 1979), we have to imagine that during Eocene time (50 m.y. ago), this island arc was located over $2500 \mathrm{~km}$ farther south and that its present position is due to crustal shortening accomplished later during the Cenozoic, as discussed by Molnar and Tapponnier (1975) and Tapponnier and Molnar (1976).

The southern Tibetan Plateau could easily be viewed as part of Stöcklin's Central Domain. However, the simple fact that it was separated from the Central Plateau by an ocean basin of Jurassic to Lower Cretaceous age leads us 
to treat this subregion as a separate entity. It would be plausible to assume that Region II represents another Gondwana fragment, but we did not hear of any positive indicators such as upper Paleozoic tillites and Gondwana floras; and in apparent contradiction, Hsü (1978) reports Cathaysian floras from this area. Note also that paleomagnetic determinations reported by Xiangyuan et a1. (1977) and discussed by Molnar and Chen (1978) are from near Lhasa in Region II.

\section{The Indus-Yaluzangbu (Tsangpo) Fracture Zone}

This zone is discussed in detail on pp. 30-41 of the Notes on Tibetan Geology. The ophiolites of this zone may be viewed as the outer arc located in front of the volcanic arc of Region II, and separated from it by a now deformed fore-arc basin which was filled with the sediments of the Indus-Molasse and the Rikaze (Shigatse) Group of Cretaceous to lower Tertiary age.

Thus, the Indus-Yaluzangbu fracture zone is an outer arc that formed the border of the Eurasian continent in Late Cretaceous to Paleocene times and which marked the conclusion of Jurassic to Cretaceous accretion to Eurasia. The approximate timing of this accretionary process was equivalent to the late Kimmerian events discussed by Stöckl in for the Middle East and is also equivalent to the Yenshanian events discussed by Chinese geologists. In Tibet, the accretion resulted in the consolidation of the Central and Southern Tibetan Plateau without, however, providing the high relief as indicated by the widespread occurrence of shallow marine Upper Cretaceous strata throughout the plateau ( $\mathrm{Li}$ et al., 1979). Open marine Paleogene (including some pelagic forams) is reported from the south flank of the Tarim Basin, the Tethys Himalayas, and - if we accept the Lockartia(?) mentioned by Molnar and Chen (1978) from Region II. Clearly, the Tibetan Plateau reached its present altitude later in the Cenozoic as a consequence of crustal shortening following the collision between India and Eurasia.

\section{YENSHANIAN EVENTS IN EASTERN CHINA}

The Yenshanian orogenic events of the Chinese geologists cover the same time span as the Nevadan-Laramide events of North America, that is Jurassic to Late Cretaceous. Major unconformities in some of the sedimentary basins of eastern China occur between the Lower and Middle Jurassic (early Yenshanian), at the Jurassic-Lower Cretaceous boundary (mid-Yenshanian), and at the base and - less important - at the top of the Upper Cretaceous (1ate Yenshanian). In the sedimentary basins of eastern China which are filled with continental sediments of Jurassic to Tertiary age, the Jurassic formations are also characterized by widespread volcanics, suggesting that these basins were initiated in an extensional regime during Mid-Late Jurassic times. Much of the later Yenshanian deformation involves extensive block faulting (for a summary, see Huang, 1960).

Most important and striking, however, is the widespread invasion of eastern China by granitic intrusions, which cut discordantly across the preexisting major structural provinces (compare Fig. 1 with Fig. 3). This 
invasion of much older provinces by granitic rocks is quite characteristic and represents an unusual mode of orogenic activity. It has so far received little attention by geologists in the West. Because it is difficult to circumscribe the landward boundary of Mesozoic orogenic activities in China, Bally and Snelson (1980) have used an envelope around all Mesozoic-Cenozoic intrusives in China to define that boundary. Sedimentary basins of eastern China that were formed east of and within that boundary appear to have an extensional origin. (The Sichuan Basin is an exception, as it is a remnant of an older platform surrounded by later compressional folded belts.) Sedimentary basins outside that boundary - or Chinese-type basins - were initiated during a dominantly compressional regime.

In the far northeast of China, we find the Yenshanian Nadanhada Mountains fold belt. Along the Wusuli (Ussuri) River is a postulated subduction or fracture zone. The situation is described by Li et al. (1979) as follows:

"In this region, there is a great thickness of eugeosynclinal formations from the Permo-Carboniferous to the Jurassic, which include basic pillow lavas, greywackes, radiolarian siliceous rocks, etc. The Nadanhada folded belt was cut by a meridional deep fracture into western and eastern parts. An ophiolite suite is found within the Lower Permian to the east of the deep fracture, while west of it, the ophiolite is emplaced in Upper Triassic. Ultrabasic rocks are overlapped by Jurassic in which pebbles of ultrabasic rocks can be seen."

The Nadanhada belt may be interpreted as a late Paleozoic-Triassic outer island arc which has been subsequently intruded by Yenshanian batholiths.

\section{CENOZOIC TECTONICS IN CHINA}

Because they can be related to earthquakes, there is naturally a great awareness of Quaternary and recent tectonics in China. The polycyclic concepts of Huang (1977 and earlier) also show an equally great awareness of Tertiary tectonic overprinting throughout China that was a consequence of the Himalayan orogenic movements. Despite this, it is remarkably difficult to isolate in China the effects of Tertiary tectonics from earlier events.

In recent years, Molnar and Tapponnier (1975, 1978) and Tapponnier and Molnar (1976, 1977, 1979) have done much work to clarify some of these aspects. Following these authors, the subduction of oceanic lithosphere along the southern margin of Eurasia ceased some 40-50 m.y. ago, when the Indian continent collided with the Eurasian continent. As the two continental masses kept moving against each other at a rate of about $50 \mathrm{~mm} / \mathrm{yr}$ during the last 40 m.y., much crustal shortening occurred, forming the Himalayas and raising the Tibetan Plateau to its present high altitudes. Furthermore, large blocks moved laterally along strike-slip faults, causing the squeezing of large segments of eastern China in an eastward direction. Some Chinese workers, however, 
attribute some late Cenozoic tectonic features in eastern China as resulting from interactions between the westward-moving Philippine Sea and Pacific Plates with the Asian Plate (Lee, 1978; Wang, 1979; Zhang, 1979).

Combining the interpretation of satellite photographs with earthquake studies, Molnar and Tapponnier (1975, 1978) and Tapponnier and Molnar (1977, 1979) produced a number of maps which show the distribution of active faults in Central Asia. On our map (Fig. 1) the most important of these are shown. In addition to these faults, our map shows a number of faults and folds which are of major importance, but many of which are no longer active. Most of them appear to be of Tertiary age, because they offset Upper Cretaceous or younger formations.

In other words, the brackets for the time of deformation of these features is such that they may be interpreted as the consequence of postcollisional deformation in China. However, because these features show no obvious late activity, they cannot be interpreted as post-collisional events with complete certainty. Some of the faults and the folding affecting the Yangtze Platform and the South China fold system may fall in this class.

A11 in a11, it may be concluded that extensive deformation has affected the whole of China during post-Eocene times.

SOME COMMENTS REGARDING DEEP FRACTURES AND THE POLYCYCLICAL EVOLUTION OF CHINA

As remarked in our Introduction, Huang (1960, 1977, and other publications) has emphasized the polycyclic nature of Chinese tectonogenes is as opposed to the "monocyclic conception" of some European and Soviet geologists. There is no question that the geologic provinces of China have been worked over several times by tectonic processes. This is witnessed by the involvement of Precambrian basement in the Tertiary Himalayas, intensive Tertiary faulting affecting the whole of China, the deep penetration of older terranes by Yenshanian granitic intrusions (Fig. 3), the involvement of Variscan and earlier folds in the later Indosinian deformation, and numerous other examples.

Chinese geologists also emphasize the importance of deep fracture zones (see classification of Huang on Tables 1 and 2). Again, the surface evidence and the seismic evidence for the existence of these fracture zones are convincing. However, except for the Himalayan-Burma fold belt, the evidence for deep earthquakes in the lower crust and deeper appears to be less convincing over much of mainland China.

Is there any evidence for the perennial nature of these fracture systems and for their reactivation during a number of orogenic cycles? In the Chinese geologic literature, it is often implied that the main structural units are outlined by deep fractures that have been polycyclically active since 
Proterozoic, Paleozoic, or Mesozoic times (see Huang, 1977). This conception puts a high premium on specific evidence supporting the longevity of the subvertical fracture zones. Unfortunately, such evidence is lacking.

In a plate tectonic context, changing plate configurations, changing ocean spreading patterns, and the modification of plate distributions and motions are al1 bound to cause discordant tectonic overprints of pre-existing orogenic trends. In other words, individual cycles and subcycles within polycyclic tectonic provinces would show as regionally discordant patterns on tectonic maps. Pre-existing fracture systems would only be reactivated if the basic plate configuration and motion did not change substantially during the orogenic process. Particularly with a continental collision where crustal shortening is often achieved by crustal thrust faulting and strike-slip faulting, it is likely that older orogenic trends would be discordantly intersected by such faults. In this perspective, major "worldwide" unconformities such as the ones used by Stille (1924) to support his tectonic orogenic phases would merely indicate a switch from one plate configuration to a discordant succeeding plate configuration. Such a switch then would cause a change of the tectonic regime or a new cycle in a polycyclic system.

Because of the discordant relation of succeeding tectonic cycles and their patterns, it is really not quite realistic to draw tectonic maps in the style shown on Figure 1. Inevitably, such maps mix discordant succeeding tectonic cycles and probably wrongly imply that such patterns were regionally more or less concordant and bounded by some long-lived fracture zone. In this situation, it may be better to draw separate maps for each separate cycle. Such maps would help a great deal to shed more light on the complexities of the tectonics of China.

On the other hand, one may quickly point out that the apparent linearity of a number of the old subduction zones and sutures indicated in our map (Fig. 1) no doubt led both Chinese and Soviet authors to postulate the long-lived nature of these fracture zones. The example of the Indus-Yaluzangbu fracture zone, however, suggests that an earlier overthrusted ophiolitic zone with relatively shallow dip was later faulted by steeper faults of an opposite vergence; and it is the combination of the two events which accounts for the linearity of the suture zone.

To better resolve these questions, it would be particularly important to concentrate and combine geophysical and geologic studies along the major fracture zones. Particularly crustal reflection, wide-angle reflection, and refraction profiles could help much to characterize the nature of these deep fracture zones.

\section{SOME SUGGESTIONS FOR FUTURE WORK}

This somewhat uneven and superficial review of the Tectonics of China would serve little if it would not lead to better problem definition. It would 
be tempting to submit a very long list of projects. Let us, however, list just a limited number of points:

- Generally speaking, geologists in the West do not master the Chinese language and only a few are bound to remedy the situation by learning this difficult language. It would be most useful if through the combined efforts of some earth scientists inside China and outside China a synthesis were written in English. The main purpose of such an effort would be to make the work of our Chinese colleagues more accessible to others and, consequently, to permit a more enlightened dialogue. Above all, such a project would help to define and prioritize problems which could be tackled jointly.

- One of the great difficulties we encountered was the general unavailability of large-scale detailed maps and sections (i.e., maps and sections on scales of say 1:50,000 and larger). The example of the Soviet Union shows that geologic conclusions that are not documented by such detailed maps and sections have of necessity a very low degree of credibility.

Detailed and paleontologically documented stratigraphic sections appear to be more commonly available but are unfortunately not translated. These also often lack precise location.

- The time appears to be ripe for our Chinese colleagues to produce a Stratigraphic Atlas of China. A large amount of new data has been collected in past decades and the basic correlations have been made (see Chinese Academy of Sciences, 1979). It would now be interesting to see whether the major suture zones that have been mapped in a reconnaisssance fashion in fact define different paleogeographic realms that may have been separated by major oceans. Much more paleomagnetic work is needed to provide - even tentative - reconstructions, but in the meantime, stratigraphic and paleogeographic provinces could be redefined with greater accuracy. Such work is always based on the quality of the stratigraphic and paleontological control, but stratigraphy done in a plate tectonic perspective could lead to substantially different environmental interpretations. These in turn could aid in the exploration for mineral and fossil fuels.

- The complex tectonic history of Chinese structural provinces calls for as precise a definition as possible of the tectonic units and their position through time. It would be immensely useful to undertake large-scale but detailed paleomagnetic studies for various intervals in each of these structural elements, in order to help delineate plates and smaller terranes and their relative positions through time. 
- The widespread distribution of granitic intrusions of many ages discordantly superimposed on top of each other should encourage people to do detailed radiometric determinations, combining the different methods and with fission track studies. If such studies are undertaken in many different areas, the crustal evolution and uplift history of China would be much better understood.

- We did get a fine review of the general distribution of ophiolites, melanges, and suture zones in China. Details regarding the ages of rocks comprising the ophiolitic sequences and the timing of emplacement, however, are poorly documented or unknown. It would now be most useful to obtain a much more detailed documentation of the geochemical evolution, the stratigraphy, and the structural evolution of such zones.

- Clearly, detailed seismic reflection, wide-angle reflection, and refraction work is needed. As already mentioned, this work would be particularly useful for the understanding of the many deep fracture zones reported by Chinese earth scientists. Such studies are expensive, but they could be most beneficial to better understand earthquake activities.

- Sedimentary basins are being explored by economic geologists in China, using various subsurface techniques including reflection seismic and drilling. It is of critical importance that such data be integrated with surface geologic work in the adjacent outcropping folded, and faulted uplifts. The history of basins and the adjacent uplifts is so intimately linked that one cannot be easily understood without understanding the other.

- Stratigraphic studies are greatly enhanced by complementary studies of the sedimentology of the sequences. Such sedimentologic studies are of great importance in unravelling the orogenic history of folded belts in China.

- A11 structural provinces of China are of great tectonic interest, so that it is difficult to select preferentially areas of particular interest. Nevertheless, we would like to emphasize the great importance of the Tibetan Plateau, the latitudinal Kunlun, Nanshan and Qinling fold systems, and the meridional Sanjiang fold systems.

- Last but not least, it would be most useful to devote special attention to the Precambrian evolution of China and to relate various Precambrian provinces with each other or else to contrast them. 
NOTES ON TIBETAN GEOLOGY

\section{INTRODUCTION}

One week of field trips and a limited number of briefing sessions are by no means sufficient to describe adequately what is known about the Tibetan Plateau. However, because so little of this has been reported outside China, we did try to pull our observations together. At best, our efforts can be no more than an attempt - hopefully useful - at geologic journalism.

The maps and figures accompanying these notes were kindly provided by the Tibetan Bureau of Geology and to the best of our knowledge represent the first detailed illustrations since the work of Hayden in 1907.

\section{REGIONAL GEOLOGY OF THE TIBETAN PLATEAU}

The geologists now working in Tibet differentiate four main regions (Figs. 1 and 2) which are separated from each other by what are described as deep fracture zones. From south to north, these regions and fracture zones are: Region I or Southern Block, bounded to the south by the Himalayan foothills of India; the Indus-YaTuzanbu (Tsangpo) or I-Y fracture zone; Region II, the Nianging-Tanggula Block or the Lasa (Lhasa) folded belt, which is subdivided from north to south into three subregions; the Banggong Hu-DongiaoNujiang (B-D-N) fracture zone; Region III, the Central Tibet Plateau, which is subdivided from east to west into three subregions; the Jinshan-Ailaoshan ( J-A) fracture zone and its western extension; Region IV or the Kekexili Block; and Region V, the Kunlun Block. The presentation to us of these subdivisions was limited to the Xizang (Tibet) region, but their extents outside the administrative borders are also shown on the map (Figs. 1 and 2).

Region I, the Himalaya, has in recent years been described and summarized by a number of authors (e.g., Gansser, 1964, 1977, 1980; Lefort, 1975). The reports of the Mount Jolmo Lungma Area Scientific Expedition (1966-68) unfortunately were not available to us in a comprehensive translation. However, the summary by Mu et al. (1973) provides substantial paleontologic and stratigraphic documentation, and Chang and Cheng (1973) discuss the regional geology. Figure 4 is a summary of the stratigraphy of the area following Mu et al.; our Chinese colleagues pointed out that the column should be amended to show two unconformities within the Permocarboniferous. Lefort (1975) shows a generalized correlation of this stratigraphic column with other sections in the Tethys Himalayas and illustrates its relation to the geology of India. 
Region I is underlain by the metamorphic basement of the Main Central sheet (the Tibetan* slab of some authors) and its overlying cover of Sinian (late Precambrian) to Tertiary sediment. In China that basement has yielded radiometric ages of 640-660 m.y., but it has also been intruded by young granitic rocks providing a 10-20 m.y. radiometric overprint (see also Jain et al., 1980). These conclusions are apparently based on $\mathrm{K} / \mathrm{Ar}, \mathrm{U} / \mathrm{Pb}, \mathrm{Rb} / \mathrm{Sr}$ dates, but we lack more specific information. Five metamorphic Barrovian zones are recognized with in the basement (chlorite, biotite-muscovite, garnet, staurolite, and kyanite). Elsewhere in the Himalayas metamorphic basement events have been recorded at 1800 and 1400 m.y. (Thakur, 1977; Gansser, 1979).

Paleozoic formations generally crop out in the southern parts of Region I, and underlying metamorphic rocks are in transition with the overlying non-metamorphic lower Paleozoic platform carbonates. These are followed by possibly Upper Devonian quartzose sandstones, which in turn are overlain by Carboniferous clastics. An unconformity may separate these units from an overlying upper Carboniferous-Permian sequence, which has carbonates in the Permian and a Glossopteris flora in the Lower Permian. Thus, the Paleozoic appears to be a shallow-water sequence deposited on a relatively stable platform.

The Mesozoic sediments of southern Region I differ somewhat from those of northern Region I. Only the latter are shown on the maps of Figures $9 \mathrm{a}$ and $9 \mathrm{~b}$. Triassic carbonates and clastics to the south seem to give way to widespread flysch-like turbidites in the north, which have yielded some lamellibranchs (Formation $\mathrm{T}_{3}^{T}$ of the map on Figures $9 \mathrm{a}$ and $9 \mathrm{~b}$ ). The Lower and Middle Jurassic in the south consists of limestones, quartzose sandstones and shales, and the Upper Jurassic equivalent of the well-known Spiti shales (Gansser, 1964) while to the north, quartzose feldspathic sandstones and calcareous shales are found in the surroundings of Jiangzi (Gyangtse). Cretaceous carbonates and clastics to the south appear to be replaced in the north by a dominantly clastic sequence, with prominent outcrops of black carbonaceous shales along the road east of Jiangzi. Upper Cretaceous pelagic faunas are reported from limestones in the upper parts of this sequence. One may conclude that Mesozoic sediments reflect a transition from deeper water in the north to shallower water in the south. Finally, Paleocene and Eocene carbonates are described from the southern area.

Chinese and other geologists generally agree that the Himalayan Tethys sediments represent the northern margin of the Mesozoic India-Gondwana

\footnotetext{
*The northern part of the Himalaya clearly is in Tibet. This has caused many authors to loosely refer to the area as Tibet. A major fracture zone separates the Himalaya in the south from the Transhimalaya and the main Tibetan Plateau to the north. Therefore, it would appear to be preferable to avoid the term Tibetan slab to prevent confusion with more northern regions of Tibet.
} 
segment. Note, however, the absence of reported Paleozoic glacial deposits in this segment of the Himalayas, but on the other hand, also note the presence of Glossopteris floras (see also Hsü, 1976, 1978). The overall impression is that the northern margin of the Indian subcontinent was a passive margin deepening to the north at least after the Permian or Triassic. Thus, the Triassic flysch sequences may well represent the continental rise of such a margin rather than deposits that are related to orogenic events.

\section{THE INDUS-YALUZANGBU (I-Y) FRACTURE ZONE}

This zone, which separates the main Himalaya from the Transhimalayan Range, has in recent years often been described as a major suture zone; Chinese geologists also like to refer to the zone as a deep "trans-lithospheric" fracture (Huang, 1978). This zone is best known in the Kailas region, northwest of Nepal and farther west in the Ladakh area. Much of what has been written is based on the observations of Gansser (1964, 1977, 1980) and Frank et al. (1975). The maps and sections on Figures $9 a, 9 b, 10$, and 11 were given to us by the team of the Tibet Bureau of Geology but redrafted for better reproducibility to facilitate comparisons with the work done in different regions.

In a structurally very complex belt such as the I-Y zone, it is pointless and naive to single out one contact, a fault, or any other line on the map and to declare it to be "the" suture. Instead, we prefer simply to describe the area proceeding from north to south. To the north of the I-Y zone occur the granitic intrusives of the Transhimalayan Range (the Nianqing Tanggula Range) or Subregion II described below. These granites yield K/Ar ages ranging from 95-37 m.y. with the bulk between 40 and $70 \mathrm{~m} . \mathrm{y}$. These granites take a similar position to the ones reported from the Kailas area and from Ladakh. The latter are presumed by Frank et a1. (1975) to be of CretaceousEocene age.

The basal conglomerates of the 6000-7000 m thick Rikaze (Shigatse) Group unconformably overlie the granites. Time did not permit us to see this contact, which is clearly indicated on the map. The stratigraphy of the Rikaze Group is discussed in some detail in Volume I of the Mount Jolmo Lungma Expedition Report (pp. 175-179). The Rikaze Group is an impressive sequence of folded rhythmically bedded sandstones, siltstones, and shales, which dominate the geology of the surroundings of Rikaze. A sandstone sample collected from a rhytmite in the formation on the outskirts of Rikaze is a classic volcanigenic wacke with grains of dominantly andesitic composition as seen in thin section. Light weathering of apparently highly calcareous siltstone beds form striking marker horizons and may be the light-colored bands that are visible on Landsat images.

Many of us found similarity in appearance with the Great Valley sequence of California and other flysch-like sequences. Our Chinese colleagues, however, insisted that the sequence was dominantly continental. The sequence was at one time thought to be of Tertiary age, but a number of fossils were collected from 
limestone beds within the Rikaze sequence Orbitolinas from the lower part suggest a Cenomanian age, and Mammites and Plesioptygmatis indicate Upper Cretaceous age (see also Mount Jolmo Lungma Expedition, v. 1, 1966-68; Mu et al., 1973). Wu et a1. (1977) described the Rikaze Group in some detail; they did compare it with Gansser's Indus Molasse. We quote from their Abstract: "North of the ultrabasic belt occurs the well-known Rikaze Group of Late Cretaceous, which is composed of conglomerate and coal-bearing detrital deposits in the basal part, red sandstone and conglomerate in the lower part, limestone in the middle and flysch in the upper, respectively named the Qiuwu Formation, Qiabulin Formation, Sangzugang Formation and Angren Formation."

Driving west from Rikaze, we were impressed with the dominant southern vergence of the spectacular folds which are molded in the Rikaze Group.

It is logical to correlate the Rikaze Group with Gansser's Indus Molasse of the Kailas region and Frank et al.'s (1977) Indus Molasse-Hemis conglomerates of the Ladakh area. The onlap relation on the Transhimalaya granites and the overall character of the Rikaze Group would suggest this. The flyschoid character is also noted by Frank et al. (1977) but deemed by them to be more apparent than real for reasons that are not altogether clear to us. Unfortunately, we have no details from the Rikaze Group such as pebble descriptions, sedimentological features, etc., to make more detailed comparisons.

The main inconsistency with the Indus Molasse is the occurrence of marine Cenomanian and Upper Cretaceous faunas that occur in addition to the Upper Cretaceous floras reported by workers in Tibet. Thus, the Upper Cretaceous age of the Rikaze Group contrasts with the Eocene or younger age suggested by Frank et al. (1975) on the basis of pebbles containing Alveolinas and nummulitic limestone intercalations reported south of Ladakh. Also, the dominant southern vergence of the folds may be typical only for the Rikaze region.

Because the similarities between the Indus Molasse and the Rikaze Group are so striking, it is tempting to try to reconcile the divergent paleontologic ages of the two formations, but before so doing, more careful stratigraphic and paleontologic work and documentation is needed. Conceptually, a model analogous to the Great Valley of California (Ingersoll, 1979) could be postulated in which the lower portions of the Indus Molasse-Rikaze Group are Cretaceous while the upper portions are Eocene. Progressively younger strata would onlap the granites.

The backbone of the I-Y fracture zone is the narrow belt of ophiolites (Figs. 9a, 9b, and 10). A detailed section (Fig. 11) shows the area we visited. The zone may be followed over a length of about $1400 \mathrm{~km}$ and is the easterly continuation of the ophiolites described by Gansser (1964, 1977, 1980) and Frank et al. (1975). The following description is from the guidebook provided to us by the geologists of the Tibet Bureau of Geology: 
"Cross section of ophiolites at Zia Lu Village, located $22 \mathrm{~km}$ to the SE of Rikaze (Fig. 11), from south to north the section consists of:

(1) Red-purplish siliceous rocks intercalated with small amounts of red siliceous shale and coarse-grained sandstones. In the red-purplish siliceous rocks have been found the radiolarians which are determined to be Sethocyrtis spp., Theoconus spp., Hemicriptocapsa spp., etc., whose age is ascribed to the Middle to Late Mesozoic.

(2) An ultrabasic unit, chiefly includes peridotite and minor harzburgite. It is in fault contact with red-purplish siliceous rocks, the fault contact zone is usually characterized by distinct schistosity.

(3) Basic intrusion, chiefly consists of gabbro associated with diabasic gabbro and diabase, which often occurs as inclusions or xenoliths in the ultrabasic intrusions.

(4) Basic volcanics and flysch-subflysch sediments, the former mainly consists of basalts (amygdaloidal basalts), spilites and tholeiites with pillow structures associated with small amounts of red-purplish siliceous rocks containing Cretaceous radiolarians (Lithocampe spp., Dictyomifra spp., Cenellipsis spp., Cromyosphaera spp., etc.); the latter (flysch and subflysch) mainly consists of shales, siliceous shales fine-grained sandstones, sandstones with small lenticular intercalations of limestone.

The ultrabasic unit and basic volcanics in this regions are generally in fault contact either with the siliceous rocks or with the flysch sediments and appear to be allochthonous.

The petrochemical data of the basic lavas of the ophiolites (including $\mathrm{Na}_{2} \mathrm{O} / \mathrm{K}_{2} \mathrm{O}$ versus $\mathrm{Na}_{2} \mathrm{O}+\mathrm{K}_{2} \mathrm{O}$, the frequency distributions of $\mathrm{SiO}, \mathrm{TiO}_{2}, \mathrm{CaO}$, $\mathrm{MgO}$, and $\mathrm{TiFeo} / \mathrm{Mgo}$ and the $\mathrm{Ti}-\mathrm{Zr}-\mathrm{Y}$ and $\mathrm{Ti}-\mathrm{Zr}-\mathrm{Sr}$ triangular diagrams) have been compared with those of the Mesozoic and Cenozoic ophiolites (data from A. Miyashiro's and J. A. Pearce's work) and reveal that the basic lavas along the Yaluzangbu (Tsangpo) River and in the region south of the Yaluzangbu River are characteristic of ocean-island and ocean-floor tholeiites which are quite different from calc-alkali volcanics in the region north of the Yaluzangbu River."

Our own impression of the Xialu section from field observations, discussions with our guides (especially Zhou Xiang and Xiao Xuchang) and some subsequent thin-section and paleontological study is as follows: The ophiolite is dismembered and does not form a complete sequence. Peridotite greatly predominates, forming a section about $7-8 \mathrm{~km}$ thick (Zhou Xiang, personal communication). The peridotite is faulted against small remnants of pillow lava and flyschoid sediments on the north, and against a thick sequence of radiolarian chert on the south. Gabbro and sheeted dike members of the ophiolite sequence are missing and may possibly be faulted out. The basic intrusives described in the guidebook (paragraph 3 above) and shown schematically in Figure 11 are only smal1, partly dismembered gabbroic and metagabbroic (amphibolite) dikes that occur at a deep level within the peridotite. These are syngenetic dikes, probably derived from mantle melts, that were metamorphosed and dismembered while the enclosing peridotite was still hot and flowing 
plastically. The peridotite itself, wherever we saw it, is a typical "mantle sequence" harzburgite tectonite with megascopic foliation and crystalloblastic to porphyroclastic microtextures with deformed enstatite porphyroclasts. The peridotite is variably serpentinized.

The fault-bounded volcanic remnants that occur on the northern margin of the peridotite (Xialu section) are albitized submarine basalts, chiefly pillow lava with intercalated sheet flows at one locality and a $1 \mathrm{~m}$ thick interbed of red radiolarian chert. Along strike with this locality two lenticular pods of chert up to $10 \mathrm{~m}$ thick occur interbedded with basaltic breccia. Bulbous pillows and tubular pillows with longitudinal growth striations are well preserved. These pillow forms and especially the sheet flows are typical of mid-ocean ridge basalts (Ballard and Moore, 1977; Moore, 1979; Ballard et al., in press). The nearly nonvesicular chilled pillow rims indicate eruption into very deep water (Moore and Schilling, 1973), and the petrographic character of the lavas (aphyric, olivine phyric, and olivine-plagioclase phyric basalts) are of the types most common among ocean-ridge basalts. The radiolarian chert intercalated within the pillow lava further suggests that the ophiolite formed in a deep-sea setting that received mainly pelagic sedimentation.

The above descriptions apply only to the local section near Xialu. More generally, the ophiolite along the Yaluzangbu zone is dismembered and nowhere exhibits a complete stratigraphic sequence. Alpine-type peridotite predominates along the $200 \mathrm{~km}-$ long ophiolitic belt extending SE and SW of Shigatse (Rikaze, Figs. 9 and 10). The great extent, thickness, and superb continuous exposure of these peridotites in the high bare mountains bordering the south side of the Yaluzangbu valley are impressive and offer splendid opportunities for detailed field studies of an oceanic upper mantle remnant. However, ultramafic magmatic cumulates (dunite, wehrlite, pyroxenite) have not been recognized, gabbro is mapped only locally and does not appear to be thick or laterally continuous, and sheeted dikes are also not mapped. Pillow lava, on the other hand, appears to be quite thick where it is locally well preserved. For example, a pillowed volcanic section perhaps $1-2 \mathrm{~km}$ thick is exposed where the Rikaze-Jiangzi road cuts across the ophiolite belt (Fig. 9, east end). One gets the impression that a stratigraphic characteristic of the Yaluzangbu ophiolite may be thick volcanics and a thin, perhaps discontinuous plutonic sequence above the mantle peridotite. Such relationships are of interest because of the implications that they have for the tectonics of the parental oceanic spreading system. Large magma chambers (leaving thick plutonic sequences) are restricted to fast-spreading ridge-systems, whereas slowspreading systems are able to maintain only small, perhaps ephemeral magma chambers (leaving thin or discontinuous plutonic sequences) (Sleep, 1975; Kusznir and Bott, 1976; Hopson et al., in press). It is too early to place the Yaluzangbu ophiolite in the latter category, but future workers should pay attention to the thickness and character of the plutonic sequence. 
The thick supposedly homoclinal sequence of chert that is in fault contact against the south side of the peridotite in the Xialu section (Fig. 11, loc. 4) is predominantly red-brown in color with subordinate green and rare white zones. Intercalated nonsiliceous sediments were not seen during our rapid traverse of this section. Chert layers range in thickness from about $5 \mathrm{~cm}$ to $60 \mathrm{~cm}$, with thicker beds most common. Along the northern margin of the chert sequence there is a narrow zone characterized by a variegated resedimented grit-sized chert breccia in a chert matrix. All the chert is rich in radiolarians. Well preserved radiolarians have been extracted from two samples collected near the northern and southern margins of the sequence, and relatively poorly preserved radiolarians were obtained from the sample roughly half way through the sequence. Preliminary analys is of the samples by David L. Jones and Bonnie Murchey-Setnicker of the U.S. Geological Survey indicates that the two samples from the margins are of mid-Cretaceous (probably upper Lower) age. The one from with in the sequence is definitely older and, although the age is uncertain, it is most likely Valanginian but could be as old as Tithonian. If correct, the paleontological data suggest that the chert section is not homoclinal as depicted in the structure section (Fig. 11), but instead is either an anticline or a series of imbricate thrust sheets.

The relationship of the ophiolites to the surrounding flysch formations is important. As shown on the maps and section (Figs. 9a, 9b, 10, and 11) Chinese geologists show the ophiolites to be thrust over the Rikaze (Shigatse) Group to the north. We saw such a contact at Stop 3 (Fig. 11) where pillow lavas and some associated radiolarian cherts were thrust over flysch-like sequences to the north. Furthermore, on the map the formation $K_{2}-R$ is indicated to onlap the ophiolites and to contain ophiolite blocks. We did look at a number of outcrops of this formation near Zong Bei some $95 \mathrm{~km}$ to the west of Rikaze but in the short time available failed to see any ophiolite pebbles. A more detailed stratigraphic paleontologic correlation of the $K_{2}-R$ group with the roughly coeval Rikaze Group is needed.

Note also that on Figures $9 \mathrm{a}, 9 \mathrm{~b}$, and 10, the southern contact of the ophiolites is shown as overthrust to the south. As we will see later, regional considerations suggest that this southern thrust contact may indicate the vergence of the primary ophiolite emplacement.

To the south of the ophiolites a band of Triassic formations is shown on the map which is thrust to the south, over younger Jurassic-Cretaceous formations. Much of this Triassic formation is a flysch which appears to be in a greenschist metamorphic facies to the east of the Rikaze-Jiangzi road segment (Formation $\mathrm{T}_{3}^{1}$ ). However, to the west of that road, Formation $\mathrm{T}_{3}^{\mathrm{C}}$ is interpreted by our Chinese colleagues to be a melange formation which extends over hundreds of kilometers. In one locality that we visited, the melange is described by them as follows: 
"Mélange section at Zong Bei, located $95 \mathrm{~km}$ west of Rikaze. The Triassic sequence is widespread in this region, chiefly consisting of blackgrayish slates, sandstones interbedded with argillaceous limestones which have yielded Lamellibranchiatas and ammonoideas. There the Permian rocks occur as exotic blocks distributed (maybe chaotically deposited) in the Triassic sequence. This mêlange extends along the Yaluzangbu River, trending $E-W$ for hundreds of kilometers."

follows:

Additional comments on this locality are provided by G. Plafker as

New age data obtained from a radiolarian chert lens roughly $2 \mathrm{~m}$ thick that is in sharp contact with the enclosing Halobia-bearing Triassic shale suggest that the matrix of the mélange may be as young as mid-Cretaceous rather than Triassic as indicated on the geologic map. Radiolarians extracted from this chert are beautifully preserved and, according to D. L. Jones and B. Murchey-Setnicker of the U.S. Geological Survey, they include forms ranging in age from Berriasian to Albian, but are most probably of Aptian-Albian age.

An additional lithologic component of the melange observed by us at a nearby locality was a large mass of dark volcaniclastic sandstone, strongly pumiceous in part. This detritus was the product of intermediate to acidic pyroclastic volcanism, evidently from an arc-type source that lay not far distant. The shape of the body suggested a channel fill, although the possibility that it is an allochthonous block cannot be discounted with the limited data available. If not allochthonous, the volcanic rocks indicate a nearby magmatic arc of middle Cretaceous or younger age.

One of us (Hamilton) interpreted the structure near Zong Bei quite differently. He regarded the area as consisting of a section of Mesozoic clastic strata, metamorphosed at low greenschist facies and deformed coherently by large and small isoclines, thrust over by a coherent sheet of Permian and Triassic limestones, with minor development of friction breccia at its base. He rejects the melange designation for these materials.

An additional locality was described to us by Xiao Xuchang et al. (1979) from the Langkazi section to the SE of Rikaze (Shigatse) where Upper Triassic blocks are distributed or possibly chaotically deposited in Upper Jurassic to Cretaceous strata. A more detailed documentation of this locality is not available to us.

The precise age and the mode of emplacement of the melange sequences remains obscure. Like the ophiolites, the map and our observations suggest vergence to the north in a thrust contact, over the $K_{2}-R$ redbeds near Zong Bei. This contrasts with the southern vergence indicated by the folded Permian limestones and the north-dipping thrust which forms the south boundary of the complex. 
The melange formations described do not appear to qualify as ophiolitic melanges and it is unclear whether they formed in conjunction with the formation of an accretionary wedge or whether they may represent gliding phenomena at the rim of the Indian passive margin of the Tethys. The "symbiotic" association of the melange complex with the ophiolites mitigates in favor of an active margin accretionary wedge setting. So too does the apparent northerly source of the volcaniclastic sandstone in the melange of the $\mathrm{T}_{3}^{\mathrm{C}}$ unit. Either way the emplacement and origin of the exotic blocks remains mysterious. They may well be part of a dismembered thrust complex or else they may be genuine landslide-related olistoliths. In a very general way these complexes may correlate with the Namika flysch reported by Frank et a1. (1975) from the Ladakh area. They also appear similar to the flysch with exotic blocks which according to Gansser (1964) underlies the exotic mass and the ophiolites of the Kiogar Peaks in the Kailas Sector to the west.

Finally, it would appear to us that another melange zone occurs farther to the south where we observed Franciscan-like outcrops near the locality marked " $x$ " on Figure 9. Here, amid a broad area of Jurassic-Cretaceous clastic strata (map unit J-K, Fig. 9a) we crossed a zone that extends at least $18 \mathrm{~km}$ along the highway in which blocks up to the size of a house are chaotically dispersed in a directionless matrix of somewhat sheared sandy shale. The melange blocks are chiefly quartzite sandstone, radiolarian chert and minor limestone; no igneous blocks were found during our 1 imited search. Most of the blocks are matrix-supported and many are widely scattered. One huge knocker examined near the highway consists of banded red, gray, green, and white radiolarian ribbon chert including beds of distinctive chert matrix chert breccia that is megascopically similar to the breccia seen at the northern margin of the thick chert sequence in the Xialu section. A moderately wellpreserved radiolarian fauna extracted from the chert is similar to that from the younger assemblages in the Xialu section and is tentatively assigned a midCretaceous, possibly Cenomanian, age by Jones and Murchey-Setnicker. The similarities in lithology and the age of chert at this locality (mapped as $\mathrm{J}-\mathrm{K}$ ) with those at the locality southwest of Shigatse $200 \mathrm{~km}$ to the west (mapped as $T_{3}^{C}$ ) are striking - the main difference being the apparent absence of exotic Permian carbonate blocks at the former locality. Wu et al. (1977) also describe this formation as follows: "East of Jiangze the Cretaceous overlying conformably the Jurassic is mainly composed of siliceous and calcareous shale in the lower part (Jiabula Formation), and siliceous flysch-like deposits with exotic blocks in the upper (Zongzhuo Formation). They are roughly assigned respectively to the early and late Cretaceous in age."

These limited data suggest that melange with middle Cretaceous or younger matrix is much more widely distributed than is indicated by the geologic map. In the field, some of us favored a sedimentary (ol istostromal) origin for the melange, mainly because of the absence of evidence for pervasive shearing. However, it is difficult to explain the presence of Cretaceous chert without involving some kind of tectonic mixing mechanism. A possible explanation 
combines gravity sliding of Permian and older platform blocks into a Triassic deep sea (slope rise?) sequence followed by tectonic inclusion of oceanic chert and other exotic rocks in or near a trench during middle Cretaceous or younger subduction.

Another feature of the Jurassic-Cretaceous terrane (map unit J-K) between Jiangzi (Gyangtze) and the southeastern corner of Figure 9a are local dikes and sills, some large enough to be seen several kilometers away. These were described to us as diabase, but two dikes that we inspected proved to be strongly altered diorite and biotite lamprophyre. Note that Hayden (1907) already pointed these out. Judging from his map, these intrusions may be more widespread. Perhaps these are satellitic intrusives related to the Tertiary (Himalayan stage) granitic plutons, like those mapped farther to the west (Fig. 9a, unit 76). Young granites (10-20 m.y. by K/Ar methods) do occur south of the ophiolites. We received little information about them, but most of us presume that they are similar to the two-mica leucogranites of the High Himalaya (Lefort, 1975) which are thought to have been formed by anatexis of the underthrusting Indian crust (Hamet and Allégre, 1976; Lefort, 1975).

Obviously the information so far is not detailed enough to provide an adequate interpretation for the I-Y fracture or suture zone. Tentatively, however, and in part inspired by Frank et al.'s (1975) "Tectonofancyful," a relatively simple evolution is conceivable. One may visualize a volcanic arc during Upper Cretaceous-Paleocene times in the Transhimalaya area, and a forearc basin like the Great Valley trough filled by the Upper Cretaceous-Eocene Shigatse Group with onlap on the Transhimalaya granite complex, but also onlap to the south of the lower part of the sequence onto a structural high or outer arc supported by the ophiolites underthrust beneath it. Deformed JurassicCretaceous rocks, the Triassic flysch, and the "melange" formations would all be part of an accretionary subduction complex that includes ophiolites farther north. The primary vergence of this subduction zone thus would be to the south and the setting could well be compared with the Arakam-Yoma-Andaman arc. Such a model, however, necessitates suturing of the ophiolite to the margin of the southern Tibetan block (Region II) after the Late Cretaceous, if it originated in an open-ocean setting as discussed earlier.

The arrival of the Indian continent in mid-Tertiary would then have caused a change from a primary south-verging island arc regime to a collisional regime (see Molnar and Tapponnier, 1975, 1978) which would lead to the formation of south-dipping thrusts and a secondary north vergence. In this manner the earlier structures would be intersected by later south-dipping reverse faults. In a very general sense, the late faults may be viewed as conjugate and antithetic to the main Tertiary thrust faults observed on the south side of the Himalayas.

The proposed interpretations are not required by the data, and it is clear that more work must be done either to understand the geologic evolution of the region or to use this area to gain a better understanding of the processes happening in subduction zones. 
Indeed, one of us (Hamilton) considers that the final subduction along the I-Y suture zone was likely southward, rather than northward as is commonly assumed. Southward subduction accords with the conspicuous north vergence, and with the south dip of the ophiolitic sheets. The young, deepseated granites of the high Himalayas (10-20 m.y. K/Ar cooling ages, 01 igocene $\mathrm{Sr} / \mathrm{Rb}$ ages) and associated regional-contact metamorphism and migmatization represent the eroded magmatic arc of this southward-subduction system. Hamilton suspects that most of the "Precambrian basement" of the Himalayan axis is the substrate of the late Paleogene magmatic arc; that this terrain has moved little relative to the underlying Indian lithosphere; that outward spreading of overlying batholiths, since largely eroded, produced quasi-symmetrical thrusting of pre-existing strata to north and south; and that the inverted, upwardincreasing metamorphism of the upper south slopes of the Himalayas is a product of the batholiths. These suggestions are contrary to long-accepted interpretations, including those presented elsewhere in this report, of Himalayan structure. If these suggestions are correct, then no lithosphere continuous with that of the Indian plate has slid beneath Tibet.

Hamilton also notes that Cretaceous and lower Paleogene granites are widespread in southern Tibet, north of the I-Y suture. Leucocratic quartz monzonite occurs too close to the suture to have formed above lithosphere subducting northward from a trench near that suture. Subduction polarity of the granites is not yet established, and it is not known whether they formed in response to subduction southward from a trench somewhere to the north, or whether they formed above a northward-subducting plate and have been brought closer to the suture by tectonic erosion of the front of the overriding plate.

There also remains the question of the age and size of the ocean represented by the ophiolites, and the date of the initiation of the Mesozoic subduction. Reconstructions of India relative to Eurasia require a large distance between them in the Late Cretaceous (Molnar and Tapponnier, 1975), but the position of Region II with respect to the rest of Asia or the relative positions of Regions I and II at that time are not well known. Could Region II, or part of it, have been an island arc, separated from the rest of Asia by a large distance? Xiao Xuchang et al. (1979) argue that south of the I-Y zone a substantial ocean existed since Triassic time and that subduction may have started as far back as Triassic time. The ocean floor separating the southern Tibetan Plateau (Region II) from the Indian platform may indeed have been spreading since that time if one chooses to interpret the Triassic flysch sequences as continental rise deposits. While separation of Region II from Gondawanaland in the early Mesozoic appears to be possible, it may well be argued that the mid-Cretaceous-Eocene emplacement of the granites of the Transhimalayas roughly coincides with the subduction event and consequently, subduction would begin in mid-Cretaceous times, or roughly at the time when subduction in the northern Banggong Hu-Dongqiao-Nujiang ( $B-D-N$ ) fracture zone appears to cease. 
The work done by Jones and Murchiy-Setnicker on samples collected by Plafker sheds an interesting light on the timing of events. The thick chert sequence is believed to have originally been deposited directly on top of the ophiolite, although such a depositional contact is no longer preserved (Zhou Xiang, personal communication). The inference is based largely upon the resemblance of the younger $X i a l u-s e c t i o n$ cherts to the radiolarian chert found intercalated within the ophiolite lavas (Fig. 11, 10c. 2). Thus, it is reasoned, deposition of radiolarian ooze during ophiolite (ocean-ridge) volcanism continued after volcanism ceased, gradually building a blanket of chert on the deep sea floor with an age range from possibly Late Jurassic and at least Valanginian to mid-Cretaceous. If these relationships are correct, one may infer that the ophiolite (oceanic lithosphere) and its pelagic cover evolved in a large ocean basin, where radiolarian ooze was able to slowly accumulate for at least $30 \mathrm{~m} . \mathrm{y}$. and perhaps as much as $50 \mathrm{~m} . \mathrm{y}$. before being diluted and overwhelmed by terrigeneous sedimentation in the Late Cretaceous. Such a deduction, although compatible with models that show a wide separation of India from Eurasia during the late Mesozoic (Molnar and Tapponnier, 1975), are premature until there is better control on the structure, stratigraphy, and age of these rocks.

It is quite clear that much work remains to be done in the I-Y fracture zone. Of course, detailed surface maps, documented stratigraphic correlations, and facies studies, as well as petrographic-geochemical studies, are all needed for any interpretation. More specifically, a few studies may be singled out as potentially rewarding:

1. The only way to estimate the distance between Regions I and II in the Mesozoic is with paleomagnetic studies of coeval rocks in both regions. Such studies would allow both an estimate of the size of the ocean that lay between them (Zhu et al., 1977) and a constraint on the amount of shortening that has taken place between them and farther north since the collision (Molnar and Chen, 1978).

2. A detailed stratigraphic-sedimentalogical study of the Rikaze Group combined with detailed micropaleontologic and palynologic studies and possible radiometric dating of any tuffaceous layers. Such a study should also include correlations with the $K_{2}-R$ section which is shown onlapping on the ophiolites, as well as correlations with the timeequivalent volcanic formations of the Transhimalayas.

3. The original internal stratigraphy and compositional variation of the ophiolite should be better established, with special attention to the plutonic member. The specific "architecture" of the ophiolite, including the size and nature of its former magma chambers ( $p$ lutonic sequences), may provide clues to sea-floor spreading rates and tectonics at the site of origin. A careful study of the sediments intercalated within the ophiolite lavas will provide a valuable guide to the tectonic setting in which this oceanic lithosphere formed. 
4. Radiometric dating of the ophiolite is needed to establish the time(s) of ocean-crust formation (sea-floor spreading). The only dating methods likely to be successful are U-Pb isotopic ages of zircons from plagiogranite and Nd-Sm mineral isochrons for the gabbros.

5. Paleontological dating of radiolarians from throughout the chert sequences will establish the time span(s) of pelagic sedimentation, providing insight into the age and size of the ocean now closed along the suture zone. Systematic biostratigraphic studies of the magnificently exposed clastic sedimentary sequences with emphas is on micropaleontologic dating of the relatively abundant radiolarian and pelagic foraminifera they contain should vastly improve understanding of depositional environments and timing of orogenic events within the suture zone.

6. The melange formations need careful attention. A careful paleontological study of the components and the matrix all along the I-Y suture may be particulariy useful.

7. A number of reflection seismic traverses across the I-Y suture or fracture zone. Care should be taken to obtain shallow data as well as deep crustal data. Shallow data may be particularly useful to delineate the narrow Rikaze basin and to determine levels of decollement underlying the folded Rikaze Group. Deep crustal data would be particularly interesting to determine the depth and dip of the fracture zone. In a somewhat similar tectonic setting in the U.S. Appalachians, the COCORP group (Cook et al., 1979) has observed prominent reflectors beneath a crystalline thrust sheet transported over more than $250 \mathrm{~km}$. Deep crustal reflection data over the I-Y zone may reveal the actual dip of some of the major faults, or maybe one or more flat reflectors which would constrain the geometry of structural interpretations of the I-Y fracture zone. The reflection surveys should be supplemented by refraction and wide-angle reflection work, by gravity and magnetics. Needless to say, this suggestion is very expensive but could provide some of the most exciting geologic information of the coming decade.

8. Careful mapping, geochemical studies, and radiometric dating of the intrusives on both sides of the suture zone. So far, it would appear that older intrusives occur north of the I-Y zone and younger intrusives within the Himalayan range. It should be noted that according to Frank et al. (1975), in Ladakh the granites actually intrude the complex north-verging suture zone. In this context the contact relationship of the isolated young granitic outcrops within the Rikaze Group appears to be of much interest.

It is clear that more radiometric dating of the granitic rocks should be done. If supplemented by fission track dating, one may 
also get more specific data on cooling and the uplift history of the region; particularly if evidence for different uplift rates on opposite sides of the I-Y fracture zone is obtained.

Petrologic and isotopic comparisons offer the possibility of resolving the sources of these intrusives - remelting of crustal rocks or a mantle source.

\section{THE NIANQING TANGGULA BLOCK OR REGION II}

The southern part of the Tibetan Plateau is bounded by two deep fracture zones: the I-Y zone previously described and to the north, the Banggong Hu-Dongqiao-Nujiang (B-D-N) fracture zone. The intervening Nianqing Tanggula block or Region II is subdivided into three zones with differing characteristics as illustrated by columns II (Fig. 6), $\mathrm{II}_{2}$, and $\mathrm{II}_{3}$ (Fig. 7), which are based on notes we took and information provided by the Tibetan Bureau of Geology.

Subregion $\mathrm{II}_{1}$ (Figs. 6 and 12) in essence corresponds to the Transhimalayan Range and is dominated by widespread granitic plutons and their volcanic equivalents. The former are more prominent in the eastern Transhimalaya Range, the latter are more widespread in the western part of that range. Farther west yet, the zone continues with the Ladakh intrusives (Frank et al., 1975). In Tibet radiometric ages range from 95-37 m.y., with the bulk of the ages between 40-70 m.y. We did not obtain any accurate locations or more specific data, but we understand that the bulk of the radiometric dates are $\mathrm{K} / \mathrm{Ar}$ dates. The volcanics associated with the intrusives are mapped as shown as the $\mathrm{K}_{2}-\mathrm{E}$ unit on Figures $9 a, 9 b, 6$, and 12 , and their age is indicated to be Upper Cretaceous to Paleocene. Note that this is the same age range as previously described for the Rikaze Group. The volcanics overlie with pronounced angular unconformity folded clastics and tuffaceous sequences of Lower Cretaceous age. We saw this unconformity from a distance traveling on the road from Lhasa to Yangbajing, where to the north of the main granite bodies, preUpper Cretaceous rocks occur in an overall synclinorial distribution. All preUpper Cretaceous rocks are folded and intruded by the granites. Marine Jurassic and Triassic carbonates and some mid-Triassic volcanics are reported. From the description of our Chinese colleagues, one gains the impression that Jurassic and Triassic sediments were deposited in relatively shallow seas, very much in contrast to the flysch sequences south of the Yaluzangbu (Tsangpo).

The basic stratigraphy of Subregion $\mathrm{II}_{2}$ is shown on Figure 7 . The region appears to be the northern continuation of Subregion II 7 but without the extensive granites and volcanics. No significant structural break separates the two subregions. The Paleozoic platform sequence appears to be more complete and more fossiliferous, possibly because the lack of granitic intrusions caused less metamorphism. Our Chinese colleagues repeatedly emphasized the similarity 
of the Paleozoic sequence with that in Region I south of the I-Y suture. A metamorphic basement of either lower Paleozoic or Precambrian age may underlie the Paleozoic carbonate sequence; however, the only radiometric date reported from the metamorphics is a $23 \mathrm{~m} . \mathrm{y}$. K/Ar determination, almost surely a later overprint! Triassic and Jurassic are not described from this area but may well be present. In contrast to Subregion $\mathrm{II}_{7}$, the Lower Cretaceous is dominated by volcanic sequences, while the Upper Cretaceous does not have a significant amount of volcanics. An unconformity with in the Upper Cretaceous separates marine sediments from the overlying continental clastics. The details of the paleontologic-palynologic correlation of the Lower and Upper Cretaceous in the region are not well documented; in particular, it would be desirable to study in some detail the Orbitolina-bearing beds which have been found to date.

Subregion $\mathrm{II}_{3}$ is to the south and adjacent to the B-D-N deep fault zone. It appears that our Chinese colleagues have studied this zone, particularly in the region to the north of Lake Namu ( $\mathrm{Namu} \mathrm{Hu}$ ). They emphasize the "geosynclinal" flysch-like deep water character of the Mesozoic sequences they observed. These sequences are associated with ophiolites, which on Figure 7, column $\mathrm{II}_{3}$, are shown by Chinese geologists to have an "intrusive" contact. A plate tectonic bias would interpret these ophiolitic outcrops to be associated with ophiolitic thrust masses or imbrications, associated with a suture (Chang and Cheng, 1973).

The Mesozoic deep water sequences of Region $\mathrm{II}_{3}$ contrast greatly both with the platform regime suggested by the shallow water Priassic-Lower Cretaceous sediment of $\mathrm{II}_{\mathrm{l}}$, and with the suggested shallow water nature of Triassic and Jurassic of Zone III, which is located to the north of the postulated fracture zone. The Paleozoic is poorly known from $\mathrm{II}_{3}$ but may possibly be correlated with Paleozoics found in the subregion immediately to the south.

A major unconformity separates the intensely deformed Lower Cretaceous to Triassic deep water sequences and the associated ophiolites from much less deformed Upper Cretaceous clastics and shallow water carbonates. This suggests an Upper Cretaceous shallow water "lid" onlapping on an earlier Upper Jurassic to Lower Cretaceous suture that became stable at some time during the Lower Cretaceous. Note that Chang and Cheng (1973) had inferred a Jurassic suture whereas the newer data suggests that suturing may have occurred during Lower Cretaceous.

The extent of Region $\mathrm{II}_{3}$ on Figure 1 is shown as outlined by our Chinese colleagues. One can sense, however, that not much is known east and west of the arc north of Lake Namu (Namu Hu). A cursory look at a compilation map of Tibet prepared by the Bureau of Geology of Tibet, which we hope will be published soon, suggests widespread Mesozoic sequences in the western sector of Subregion $\mathrm{II}_{3}$ where the published geologic map of China indicates Paleozoic sequences. 


\section{THE BANGGONG HU-DONGQIAO-NUJIANG ZONE}

This zone is described by the Chinese geologists as a deep fracture zone and outlined by them as shown on Figure 1. The zone corresponds to Jinshajiang depth fracture of Huang (1978). Li et al. (1979) described this zone as follows:

"A clear geological delimitation could be deciphered in the middle part of Qinghai-Xizang Plateau from Ritu to the south of the Banggong Lake through Gaize, Anduo to Dingqing. To the north of this line, there is the Linqitang-Tanggula Geosynclinal Folded Belt (Region III) and to the south of this line, there is the Lasa Geosynclinal Folded Belt (Region I). Both were related to Mesozoic subduction activity. But the former was consolidated at some time earlier than the latter. Many ultrabasic rocks such as harzburgite, enstenite peridotite, dunite, etc., outcrop discontinuously along the line. The existence of typical ophiolite suites has been proved by the latest observation at a place near Pengcuo to the south of Anduo. But many of the ultrabasic rock bodies contact with country rock by faults. It is reported that many exotic blocks of limestone containing late Paleozoic or early Mesozoic fossils were included in sandstone and slate of Late Jurassic to Early Cretaceous at Xiaqiuka between Naqu County and Suo County. Hopefully, such kinds of mélange might be found out in other places along the above-mentioned line."

It is tempting to tie this zone to the North Transhimalayan lineament or the $32^{\circ} \mathrm{N}$ fold belt recognized by Gansser (1977) on Landsat imagery and by Molnar and Tapponnier (1978), respectively. Judging from the sketch map provided by Chinese geologists, the main fault zone trends into the lobate lineament shown by Gansser along the north shore of Banggong Hu (Pangong Tso); the North Transhimalayan line may well correspond to the south boundary of the Mesozoic "geosynclinal" sediments of Zone $\mathrm{II}_{3}$. That zone is also shown as a fold belt on the map of Molnar and Tapponnier (1978). The western B-D-N zone appears to be no longer active and over wide stretches, it is buried under Quaternary sediments. Some scattered seismicity in Tibet could conceivably be related to movement on the B-D-N zone, but fault plane solutions of earthquakes suggest normal faulting and east-west extension (Molnar and Tapponnier, 1975, 1978; Ni and York, 1978).

\section{Comparing the stratigraphy of Zone II with III 2 across the fault} zone, the following should be noted: The Paleozoic sequences appear to be similar and of platform type on both sides of the fault. As in Zone I existing data do not require that the basement underlying this province was formed during lower Paleozoic or during Precambrian time. The whole Triassic including its base is represented by what appears to be a relatively thin shallow water marine sequence, the Middle Jurassic appears to be somewhat thinner but otherwise comparable to Zone $\mathrm{II}_{3}$, except for the presence of volcanics. The main difference appears to be that the Lower Cretaceous to the north of the $B-D-N$ fracture zone appears to be continental suggesting an earlier uplift of 
Zone III $_{2}$, that may precede the final welding of the south Tibetan block (II) to the north Tibetan block (III) at the fault zone. Thus the "suturing" of the two blocks is bracketed by the presence of Upper Jurassic deep water limestones associated with the ophiolites in Zone $\mathrm{II}_{3}$, an unconformity preceding a poorly dated Lower Cretaceous continental sequence to the north of the fault and a better dated unconformity underlying Orbitolina-bearing Upper Cretaceous beds in Zone $\mathrm{II}_{3}$. The subduction and collision of Zone II and III is further supported by granitic intrusions with K/Ar ages on biotites yielding ages of $170-200 \mathrm{~m} . \mathrm{y}$. from one body near $32^{\circ} \mathrm{N} 92^{\circ} \mathrm{E}$ and ages of $99,106,114,138$, and $145 \mathrm{~m} . \mathrm{y}$. from a number of intrusions to the west and near $32^{\circ} \mathrm{N}$ and $91.5^{\circ} \mathrm{E}$. In a general manner, these ages agree with the ages reported by Chang and Cheng (1973).

REGION III AND IV: THE NORTHERN TIBETAN PLATEAU OR THE LINQITANG GEOSYNCLINAL BELT (III) AND THE KEKEXILI-JINSHA AILAO SUBDUCTION ZONE (IV)

Although the structural evolution of the northern Tibetan Plateau appears to be less well studied than the regions farther south, Chinese geologists working there differentiate Region III (with three subregions) from Region IV (the Kekexili area).

The stratigraphy of the central portion of Region III (III, on Fig. 8 and Table 5) consists of upper Paleozoic carbonates and slates overlain by relatively thin Triassic clastics and carbonates. This is followed by a thick Jurassic marine sequence which may well be the correlative of the possibly allochthonous Jurassic sequences of Zone $\mathrm{II}_{3}$. An unconformity separates the post-deformational Lower Cretaceous clastics from the underlying sequences, and another unconformity and hiatus spanning much of the Upper Cretaceous precedes the deposition of continental Tertiary beds.

The stratigraphy of Region $\mathrm{III}_{3}$ is shown on Table 6 . This subregion merges to the west with the Lorzung-Block slate facies zone recently summarized by Norin (1946, 1979) and traced by him into the Central Pamir, where as in Zone $\mathrm{III}_{3}$ the Middle Jurassic unconformably overlies older sequences. However, specific correlations of the upper Paleozoic sequences between III $_{3}$, Norin's area and the Pamirs are not easily made. Such correlations may be of some consequence because Norin recognized what he called Permo-Carboniferous-bearing mudstones (the Horpatso series) that he interprets to be of glacial origin and that he compared with the agglomeratic slate series of Kashmir - a late Paleozoic tillite. This strongly suggests that Region III once was part of Gondwana.

The stratigraphy of Subregion III 1 is summarized on Table 4 . This area occupies the easternmost reaches of Tibet and is subdivided in an eastern and western segment. A fairly complete upper Paleozoic shallow water carbonate sequence, with some coals in the Lower Carboniferous and Upper Permian, suggests a platform environment. Lower Triassic is missing in the west and present in the east, followed by thick Upper Triassic sequences. 
Thick Middle Jurassic to Lower Cretaceous sequences, which are marine in the west and in redbed facies in the east, contrast strikingly with Subregion III $_{2}$ and raise the question whether the two subregions have not a basically different evolution. Like Region III $_{3}$ a Lower Jurassic hiatus suggests an Indosinian orogenic event, but there is also an unconformity and a hiatus responding to mid-Cretaceous deformation that thus can be followed from the Pamir Mountains into eastern Tibet.

Region IV is a small area in northern Tibet called the Kekexili area, where upper Paleozoic to Triassic sandstones and shales are deformed during a presumed Indosinian (Upper Triassic) event which is mapped by the Chinese farther to the east (Table 7).

It is worth noting that the Chinese geologists repeatedly suggested that throughout Tibet the Paleozoic rocks showed Gondwana affinities* although this led some geologists to take a fixist position. Many of them (1ike Chang and Cheng, 1973) recognized that Tibet probably consists of fragments that successively broke off of Gondwana, drifted north and subsequently collided with India. It is clear that a great deal more needs to be done to better document the timing and geometry. But this seems to be a reasonable working hypothes is as it is farther west (Tahirkheli et al., 1979).

Finally, recent expeditions to these northern parts of Tibet reveal increasing evidence for recent volcanism (see also Norin, 1979), both of alkali basalt and calc-alkaline ranges. There does not appear to be any pattern to the distribution of these different types of volcanic rocks (see map in Sengör and Kidd, 1979).

\section{QUATERNARY TECTONICS}

Although little formal attention was paid to active or Quaternary faulting, one of us ( $P$. Molnar) entered with a particular bias, that normal faulting on north-south faults is prevalent in Tibet (Molnar and Tapponnier, $1975,1978)$. In an informal discussion a number of Chinese geologists expressed a similar point of view, and on three particular occasions, some of us thought that we could see evidence for such faulting. Our route took us over a $5000 \mathrm{~m}$ pass (Kahro Pass) across a north-south range near $89^{\circ} \mathrm{N}, 90^{\circ} \mathrm{E}$ into a north-south valley to the west. On the Landsat imagery the range appears to be sharply bounded on the west, presumably by a normal fault (Molnar and Tapponnier, 1978; see also Figs. 9a and 9b, east of " $x "$ "). From the ground there indeed appeared to be a break in the slope at the foot of the range along part of it, which might represent an active fault scarp.

Near $29.2^{\circ} \mathrm{N}, 88.2^{\circ} \mathrm{E}$, clear normal faulting on planes striking approximately north-south could be seen in red conglomerates thought to be of Late Cretaceous or early Tertiary age. The data constraining the age are probably not very good.

*They did not, however, provide specific documentation, and a very informative and careful review by Hsü (1978) contradicts this view by showing two occurrences of Cathaysian floras north of the Yaluzangbu River. 
The clearest evidence for Quaternary normal faulting, however, was presented to us on a one-day trip to the Yangbajing geothermal station, some $50 \mathrm{~km}$ northwest of Lhasa.

\section{THE YANGBAJING GEOTHERMAL AREA}

The Yangbajing (Yang $\mathrm{Pa}$ Ching) geothermal area is located some $50 \mathrm{~km}$ northwest of Lhasa. The area is located in a northeast trending valley and on both sides flanked by high mountain ranges. The mountains to the southeast belong to the Transhimalaya Range which here is formed by Jurassic and Triassic rocks (see Fig. 12). The mountains to the northwest, however, are in gneiss, marbles, phyllites, and schists, which some view to be metamorphosed Paleozoics; others think of them as Precambrian basement. One Tertiary radiometric date is reported from these rocks. The range has a gentle dip slope dipping to the southeast, which suggests a tilted block with some $2000 \mathrm{~m}$ relief.

The valley of the Yangbajing geothermal field is reported to be bounded by normal faults on both sides of the valley. There is little doubt about a major fault on the southeast side, but the one on the northwest side is less obvious, al though our Chinese hosts assured us that clear offsets of Quaternary formations were observed. They mentioned slickensides indicating normal faulting, but it was not quite clear where these had been observed.

Exploration in the area started in 1976. Eight wells now produce steam which is used for a power station, a temperature of $172^{\circ} \mathrm{C}$ is reported from depth below surface of $458 \mathrm{~m}$.

The field area coincides with gravity, magnetic and resistivity anomalies, and we understood that the field was outlined by geoelectrical methods. The producing wells seem to be aligned perpendicular to the valley, which may suggest control by some transverse structural feature. The field produces from Quaternary fluvioglacial deposits. These are underlain by Pliocene beds and Miocene continental redbeds. To the northwest of the geothermal site, a fault zone cuts the Plio-Pleistocene rocks which have been hydrothermally altered. In the alternation zone, a native sulfur deposit is exploited.

The geothermal field of Yangbajing is being drilled by rigs ordinarily used for hydrocarbon exploration. We had been aware of an article by A. A. Meyerhoff (1979) discussing the discovery of some oil in Tibet (the article gives accurate locations by longitude and latitude). We looked around and eagerly inquired. We indeed were in Lhasa but could not see anything or hear from anybody about any oil wells drilled near Lhasa. As to the purported northern locations, the Chinese colleagues working in Tibet had never heard of any drilling for oil in the areas indicated. They suspected somebody may have described some organic shales which sometimes appear to be associated with some of the young continental deposits. 


\section{THE CORRELATION OF TIBETAN GEOLOGY WITH AREAS OUTSIDE TIBET}

A discussion of the correlation of the major structural units of Tibet has been included in the introductory sketch of the tectonics of China (see also Fig. 1).

SOME IMPORTANT DIRECTIONS FOR RESEARCH IN THE INDIA-EURASIA COLLISION ZONE AND THE TIBETAN PLATEAU

Nowhere on earth are there more important, more intriguing, and more challenging problems of tectonics than in the India-Eurasia collision zone. The phenomenon of continental collision is poorly understood by today's earth scientists, and the India-Eurasian zone is the prime example of the magnificent effects of a recent collision, a process which in this case began some 40 or 50 m.y. ago and which apparentiy continues in modified form today. The significance of this particular collision zone lies partly in the importance of understanding, for their own sake, the nature and the causes of the HimalayanTibetan area, which includes the earth's highest mountains and its largest, highest plateau. It also lies partly in the relevance of an understanding of a modern collision to improved understanding of former ocean basin closings and continental collisions elsewhere, for the purposes of both basic science and practical application.

Although it is presumptuous to recommend areas of study and hence imply comprehensive understanding of the current state of knowledge of the geology of the Tibetan Plateau or other parts of the collision zone after only a brief visit to the area, we attempt in the following to suggest some types of research that might hasten the advance of knowledge of this subject. For some topics, so far as we could determine, no work is being carried out at present. For other topics, work has already been begun by the Chinese, or by the Chinese in collaboration with others. In such cases, we note possible areas for accelerating, broadening, or supplementing the research effort. Finally, we write these sections with some humility, for our brief experience in Tibet demonstrated some of the difficulties of working at high elevations in remote areas and brought admiration for those who do so; such work will be far more difficult than outlining a project for the pages of a report. On the other hand, we have tried to focus our attention on projects that seem feasible based upon our brief experience in the area.

We have already proposed some specific research topics for the I-Y suture zone. In this section, we attempt to take a broader view of the whole area. Research on the Tibetan Plateau is bound to address two main topics: The complex plate tectonic evolution of the India-Eurasia collision zone and the Tibetan Plateau, and the present high uniform elevation of the Tibetan Plateau. Aside from continued structural and stratigraphic mapping at large scales (i.e., 1:50 000 and greater) we would like to single out a few problem areas. Our list is therefore selective and hardly all-inclusive. 


\section{Plate Tectonic Evolution}

As a result of our briefings by Chinese geologists, it is clear that Tibet is composed of a series of displaced terranes which appear to have collided sequentially with Eurasia thoughout the Mesozoic and early Cenozoic. At the present time the Chinese are deeply involved in determining the geologic relationships of these separate areas shown on the accompanying report as Zones I through IV. Chinese scientists have already begun to study the paleomagnetism of the rocks and sediments from this region, and the first results have been published. The results of Xiangyan Zhu et al. (1977) for Late Cretaceous-early Tertiary rocks in southern Tibet, when compared with paleomagnetic poles for Eurasia, indicate a convergence between them of 2000 to $3000 \mathrm{~km}$ (Molnar and Chen, 1978). Clearly, that study is not enough. It is obvious that an intensive investigation of the paleomagnetism of the rocks comprising the Tibetan Plateau would yield a large amount of information concerning the geologic history of the displaced terranes including information concerning their prior positions and timing of their emplacement during the formation of the Tibetan Plateau. Moreover, if much of the shortening has occurred by lateral movement of blocks out of the way of India and Eurasia (Molnar and Tapponnier, 1975), this style of deformation might be revealed by rotation of small blocks near strike-slip faults and by a general disorder in paleodeclinations. Intensive paleomagnetic studies would yield a large amount of significant data in the shortest time possible. It would also be relatively inexpensive.

Simultaneously with the paleomagnetic studies a comprehensive program of radiometric dating would make the paleomagnetic studies and other geological studies more valuable and help to restrict more closely in time the important magmatic events associated with the orogen. Also of paramount importance is the paleontologic dating of the sedimentary formations. An example of the importance of paleontological and micropaleontologic studies is shown by the success of one of our members, G. Plafker, in the dating of radiolarians in the cherts from the mélanges seen by us. The Cretaceous age which was determined will be a great aid in helping to understand the tectonic development of the region.

At the present time a large part of Tibet is $4500 \mathrm{~m}$ above sea level, clearly resulting from the collision of India and Eurasia; however, one facet of the uplift of the plateau which would be of great interest would be the uplift rate and the time that the plateau was elevated to its present elevation. This information can be obtained by fission track dating of zircons and apatite. These fission track studies would yield information with respect to the rate and timing of the uplift of the rocks forming the plateau. Since the present elevation of the Tibetan Plateau has a profound effect on the climate of Eurasia, it would be interesting and important to know when this occurred.

Another way of studying the uplift of the plateau would be to attempt to do magnetostratigraphy on the uplifted terraces of the region. If all the 
terraces were normally magnetized, one could assume that they were probably all formed during the last 730,000 yrs. If any of the higher terraces were reversely magnetized, then the rate of uplift could be estimated since they would have to be at least 730,000 yrs $01 d$.

To the south of the Himalayas in Pakistan and India, much work has been done on the magnetic stratigraphy of the Siwalik Molasse. A similar study of the magnetostratigraphy of the central Asian molasse to the north of the Tibetan Plateau (Tarim and Tsaidam Basins) would greatly help in elucidating the response of the Tibetan Plateau to simultaneous tectonic events occurring in the Himalayas. We saw a film which showed the skull of a three-toed horse Hipparion being removed from lignite-bearing clays. Magnetostratigraphy offers an excellent opportunity to date these beds and to correlate them with sediments of the same age elsewhere.

Useful glimpses of the age and tectonic history of the oceanic realms that originally separated the four main Tibetan blocks (Regions I, II, III, IV and V) are contained in the ophiolites and their original oceanic sedimentary cover, now found as dismembered remnants along the fracture zones ( $I-Y$, $B-D-N, J-A$ ) where the blocks were sutured together. A reconnaissance field and geochronologic study of these ophiolites and sediments will help to establish the age span and tectonic evolution of those ocean basins, which will help in the overall plate tectonic reconstruction of the Tibetan Plateau region. Ages as young as Cretaceous for ophiolites along the suture zones can reliably be determined by $\mathrm{U}-\mathrm{Pb}$ and $\mathrm{Nd}-\mathrm{Sm}$ methods (Tilton et al., 1980; McCulloch et al., 1980), identifying periods of ocean-floor growth between each of the blocks. Radiolaria can be used to determine the age span of pelagic sediments that rest on the ophiolites (Pessagno, 1977, 1978, 1979), thus providing minimum estimates of the longevity of these oceans. Combining reasonable sea-floor spreading rates with these age spans will give crude estimates of the minimum halfwidth of the former oceans. This approach can readily be applied to the I-Y ophiolitic belt (suture zone). Also, its possible application to ophiolitic remnants along the $B-D-N$ fracture zone, and to ophiolitic melanges within the $J-A$ fracture zone where it extends into Yunnan (Zhang, 1979) seem worth exploring.

The apparentiy large crustal thickening that has occurred in Tibet requires that eventually the lower crust will be heated to temperatures typical for 60-70 km depth. Dewey and Burke (1973) inferred that the volcanism in Tibet could be a consequence of the melting of lower crustal rocks. Relatively high seismic wave velocities in the upper mantle beneath Tibet could in fact be taken as evidence that the uppermost mantle is too cold to be partially molten and that the source of the volcanic rocks is in the lower crust (Chen and Molnar, 1980). Clearly, there is a need for a careful study of these rocks to determine insofar as possible their source - crust or mantle. Presumably, this would involve careful isotopic analyses as well as thorough studies of xenoliths carried by the volcanics. Apparently, little has been done so far. No xenoliths have been reported at all. 


\section{Present State of the Collision Zone and the Tibetan Plateau}

(a) Geologic Mapping. Mapping of the collision zone including the plateau is far from complete. In fact, it is in so early a stage as to make al1 present theories of Tibetan tectonics seem poorly founded. However, just four years ago the Chinese began a large effort to explore and map Tibet. Hundreds of geologists are involved. The immediate goal of the effort is exploration for mineral resources, but more complete and more accurate maps and other information on Tibetan geology may be anticipated over the next 5 to 10 years. Progress in understanding the tectonics of the area might be accelerated by detailed mapping of small areas carefully selected for their tectonic significance and without regard to their direct relation to mineral resources. Interaction in the field between Chinese and U.S. scientists on such techniques as dating, petrography, and tectonic interpretation would be mutually beneficial. The excellent exposures in Tibet are a positive factor; logistics may present serious problems, particularly in remote areas.

(b) Active Source Seismology. Because of the special interest of several members of the delegation, this subject received careful attention. The recent successes resulting from seismic reflection profiling of basement rocks in the U.S. by COCORP and the long-term prominence and success of this method in the search for petroleum prompted consideration of application of this method in Tibet. Somewhat to our surprise, the conditions that were observed in Tibet are especially favorable for seismic reflection profiling using either VIBROSEIS or explosive sources, much more so than for most of the U.S., for example. Except where they occasionally climb through mountain passes, the roads (typically in the valleys) are rather flat, straight, dirtcovered, and relatively free of traffic. The logistics of bringing in equipment and maintaining a field crew in high remote locations raises problems but not insurmountable ones. It is therefore technically feasible, though probably not inexpensive, to carry out seismic reflection profiling in Tibet.

On the crustal scale that would be so useful in understanding the collision process, one can reasonably consider what would surely be one of the grand experiments of earth science - a profile beginning at Geermu on the north of the Tibetan Plateau, crossing the plateau south to Lhasa, then traversing the suture zone to the west in the vicinity of Rikaze, and finally continuing south across the Himalayas to Katmandu and beyond or else south from Jiangzi through Gangtok. Most of this line could be profiled, although limited segments where the roads wind through mountain passes would have to be omitted. Cross lines are feasible in many places. A prudent plan would involve an exploratory or feasilbity study at a few key locations (such as possible sutures or subduction zones) prior to carrying out the full survey. The great thickness of the crust might require certain modifications of the technique, and experiments to determine the appropriate procedures.

At the places where the 1 ine crosses sedimentary basins, special detailed surveys of the sediments should be part of the study. The geothermal 
area to the northwest of Lhasa that was visited by the delegation is an example of one such site, but almost every geologic problem of such scale is equally suitable. On the whole, the use of seismic reflection profiling offers great promise for the solution of geologic problems in Tibet - and elsewhere in China.

Although studies of available seismic data indicate very large crustal thicknesses in Tibet, those data are scanty and lack spatial resolution. Surface-wave dispersion alone requires a relatively thick crust, but is not adequate to resolve the thickness to better than $+20 \mathrm{~km}$. A refraction study using arrival times reported by the station at Lhas $\bar{s}$ from earthquakes in Tibet requires relatively high $v_{p}$ and $v_{s}$ velocities in the mantle $(8.1+0.1 \mathrm{~km} / \mathrm{s}$ and $4.8+0.1 \mathrm{~km} / \mathrm{s})$, which in turn, together with the surface wave dispersion, imply a crustal thickness of $70 \mathrm{~km}(65-80 \mathrm{~km})$ (Chen and Molnar, 1980). These estimates are crude, and clearly refraction profiles are needed for more precise estimates and for an investigation of regional differences. Chinese scientists have attempted at least one such study, and one of the explosive sources was pictured in a movie which the delegation saw. However, the results of the study have not yet been made available. Seismic refraction profiles could follow the roads and there are sufficient bodies of water nearby to serve as source locations, so some refraction profiling seems feasible, and a beginning has been made by the Chinese. Logistics would be difficult for lines distant from the good roads.

(c) Passive Seismic Sources (Earthquakes). The total effort in earthquake seismology in China already surpasses that of the United States, for the earthquake hazard is widespread and serious there. The effort in seismology seems to be expanding and thriving. In Lhasa an informal visit to the local seismograph station by a subgroup of the delegation revealed that instrumentation there is being upgraded and expanded. Tibet is a large area, however, and in spite of the major and commendable effort by the Chinese the density of stations is sparse for some types of studies. Small arrays or networks could be used at selected sites on a temporary basis to explore local seismicity and earthquake focal mechanisms in ways and in places that would improve understanding of tectonics. Just the depth distribution of earthquakes along major faults would be interesting in an area of such unusual crustal thickness, for example; and relating seismicity and focal mechanisms to particular major faults would be well worthwhile.

Regional or teleseismic studies based on existing data are few so far and many additional studies could be made. They run the gamut from $P$ - and S-wave delay times to determination of crustal structure based on body-wave or surface-wave data. One practical problem here is the assembling of data that have been collected by stations in many different countries. 
(d) Neotectonics. Coupled with the general problems of what makes the Tibetan Plateau so high and what keeps it there are the questions of when the plateau rose to its present position and whether it is rising, falling, or otherwise deforming now. In addition to the geological implications, the effect of the plateau on past climate of surrounding regions is also of great interest. Possible studies in this connection include subjects ranging from plateau-derived sediments of the ocean floor through geodetic surveys of sutures and major faults of the plateau and its surroundings. Quaternary deformation in the plateau and in surrounding areas (such as the Red River fault zone visited by the delegation) may be revealing. 


\section{NOTES ON YUNNAN GEOLOGY}

The Red River region of southwestern Yunnan and neighboring Indochina may contain both a suture, along which China and Indochina collided in Triassic time, and a major strike-slip fault system. We requested a fieldtrip here and geologists of the Bureau of Yunnan Geology obliged generously with excursions in the area near Yuanjiang. Figure 14, redrafted from a chart they gave us, depicts the stratigraphy of the region southwest of the Red River fault system. Aithough we saw no documentary data such as detailed geologic maps, measured sections, or fossil lists and localities, it was apparent, both in discussions and in the written materials that we were given, that geologic knowledge is still sketchy. The Yunnan geologists have made an excellent start, but much must be done before interpretations can be made with confidence.

To the northeast of the Red River valley is the Yangtse Paraplatform, which in this vicinity consists of moderately deformed Mesozoic continental clastic strata overlying undated metamorphic rocks, whereas to the southwest of the valley is a broad region of northwest-trending magmatic and tectonized belts.

The first belt southwest of the Red River valley is that of the Ailao Shan, a tract about $10 \mathrm{~km}$ wide formed largely of undated migmatites (Pt, for Proterozoic, on Figure 13). We examined the migmatites at a number of localities and found them to be, as the Chinese geologists reported, everywhere retrograded, with a marked cataclastic foliation. Biotite K-Ar determinations yield middle Tertiary uplift ages, and the young uplift is consistent with the inferred young age of the nearby Red River fault system. The migmatites are overlain unconformably by red Mesozoic or Paleogene conglomerates. Within the area that we visited, the migmatites are in fault contact with undated, low- to middle-grade metasedimentary rocks. Although the stratigraphic column of Figure 14 shows a nearly complete section of Ordovician through Triassic strata, largely shallow-marine carbonates, to lie upon the migmatites, these strata are in a separate fault block in the southwest part of the Ailao Shan belt. The Paleozoic and Triassic section resembles in broad aspect that of the Yangtse Paraplatform, although the stratigraphic thicknesses assigned require, if broadly correct, that this be a continental-margin setting.

The next belt--the eastern part of the Lanping-Simao foldbelt of Figure 13--southwest of the Ailao Shan is depicted as having a stratigraphic section on the figure, but it includes, and perhaps is formed largely of, polymict melange. The belt is 10-15 km wide, and includes many lenses of serpentinite. Ophiolite components are reported by the Chinese geologists: serpentinite, gabbro, diabase, basalt, and radiolarite, the latter two in part intercalated. Breccias are widespread, and serpentinite-matrix polymict melange has been recognized. Glaucophane schist is present. The belt is dominated by low-grade metasedimentary rocks, including slate, fine-grained 
sandstone, dirty carbonates, and chert. The few dated fossils found in these materials are Middle Triassic pelecypods. At the one place where we saw these sedimentary rocks, they were at least mostly coherent; we assume that scalyclay melange may be widespread in the belt, but we neither saw any, nor heard descriptions of any, from our guides. Unconformably overlying these various materials are intermediate and silicic volcanic rocks intercalated with sedimentary rocks, mostly redbeds, that contain Upper Triassic fossils.

Our Chinese guides interpret, we believe correctly, the pre-LateTriassic part of this belt to be an accretionary wedge, formed between converging iithosphere plates. They further interpret the subduction to have been northeastward beneath China, but we are uncertain of the evidence for this. The Upper Triassic volcanic section presumably itself formed above a subducting lithosphere plate, which perhaps dipped northeastward from a trench now recorded by one of the other suture zones to the southwest. There is a broad tract of magmatic and tectonized rocks between Chinese and Indochinese plates, and a complex history of accretion and collision may be recorded.

Southwest of the Triassic accretionary wedge is another belt, more than $15 \mathrm{~km}$ wide, which we did not see. Rocks present (Figure 14) include Silurian and Lower Devonian through Triassic carbonate, clastic, and volcaniclastic strata, intercalated with mafic, intermediate, and silicic volcanic rocks; and nonvolcanic clastic strata, mostly continental, of Jurassic to Tertiary age. As the Chinese geologists conclude, the DevonianTriassic rocks may represent island-arc settings. The very long age span assigned the magmatic rocks makes a complex history likely: a single, simple island arc is most unlikely to have existed so long, and complications due to collisions, polarity reversals, and perhaps renewed magmatism after accretion to a continent, are to be anticipated.

We also saw some aspects of the Quaternary faulting and tectonics of Yunnan. Particular attention was paid to the faulting that occurred during the Tonghai earthquake of 4 January 1970. Right slip, averaging about $2 \mathrm{~m}$, was observed along a $50 \mathrm{~km}$ segment of the Qujiang fault by Chinese geologists. We visited the break at only its westernmost segment; at the one site where the offset could still be accurately measured, it was about $1 \mathrm{~m}$. Aftershocks located using a temporary array of stations indicated a northwest trend of activity, parallel to the fault break, but the uncertainties in the locations $(\sim 5 \mathrm{~km})$ were too large to define any new features in the fault pattern. The fault plane solution showed nearly pure strike-slip motion. Retriangulation of a network surrounding the rupture area yieided results in accord with right lateral slip of $2 \mathrm{~m}$ on a fault extending to about $15 \mathrm{~km}$ depth. A releveling survey revealed little vertical motion except at the east end of the rupture where a graben extends south from the Qujiang fault. There are numerous young north-south grabens in Yunnan, and the Chinese geologists interpret the Qujiang fault as a transform fault between two such grabens. These grabens are clear on the satellite imagery of the region (Tapponnier and Molnar, 1977). 
The dominant active feature in Yunnan may be the Red River fault. It is remarkably clear on the Landsat imagery (Tapponier and Molnar, 1977), but throughout the last 300 to 400 years, the duration of the historic record, there has not been a noteworthy earthquake $(M>6)$ associated with it. We crossed the fault near Yuanjiang, where it is marked by prominent relief, but we could not see convincing evidence that demonstrated a sense or style of motion. The Chinese geologists assured us that elsewhere right-lateral stream offsets are clear. The right slip is consistent with the displacement on the parallel Qujiang fault during the Tonghai earthquake. The Red River fault is also important because it seems to bound the normal faulting to the north.

Although less discussion was given to the 29 May 1976 Lungling earthquakes than to the Tonghai earthquake, the fault plane solution determined by the Chinese from their data is similar to that determined by one of us (Molnar) and shows nearly pure strike-slip faulting. The solution is similar to that for the Tonghai earthquake, but since the Chinese have recognized faults trending northeast but not southwest in western Yunnan, it seems more likely that left slip occurred on a northeast trending fault than right slip on the conjugate plane. Despite an intensive search, no evidence for surface faulting was found by Chinese geologists.

Thus, much of Yunnan seems to be experiencing east-west extension and north-south compression. This strain field manifests itself differently in different regions but may be quite uniform. The pattern presumably is a byproduct of the relative motions of India and Eurasia (Tapponnier and Molnar, 1976). 


\section{REFERENCES}

Acharyya, S. K., 1977, Paleaogeography and orogenic evolution of the eastern Himalayas, in Jest, C. (ed.), Himalaya: Sciences de la Terre: Colloques Internationaux du Centre National de la Recherche Scientifique, no. 268, Paris, p. 21-30.

Andrieux, J., Brune1, M., and Hamet, J., 1977, Metamorphism and relations with the main central thrust in central Nepal, 87Rb/84Sr age determinations and discussions, in Jest, C. (ed.), Himalaya: Sciences de la Terre, Colloques Internationaux du Centre National de la Recherche Scientifique, no. 268, Paris, p. 37-40.

Argand, E., 1924, La tectonique de 1'Asie: C. R. 13th Cong. Geol. International, v. 1, p. 170-372.

Ballard, R. D., Holcomb, R. T., and van Andel, Tj. H., 1980, in press, The Galapagos rift at $86^{\circ} \mathrm{W}$ : 3. Sheet flows, collapse pits, and lava lakes of the rift valley: Jour. Geophys. Res.

Ballard, R. D., and Moore, J. G., 1977, Photographic atlas of the Mid-Atlantic Ridge rift valley: Springer-Verlag, New York, $114 \mathrm{p}$.

Bally, A. W., and Snelson, S., 1980, Realms of Subsidence, in Facts and Principles of World 0il Occurrence: Can. Soc. Petrol. Geol. Mem. 6.

Bird, Peter, 1978, Initiation of intracontinental subduction in the Himalayas: Jour. Geophys. Res., v. 83, no. B10, p. 4975-4987.

Bird, P., Toksöz, M. N., and Sleep, N. H., 1975, Thermal and mechanical models of continent-continent convergence zones: Jour. Geophys. Res., v. 80, no. 32 , p. 4405-4416.

Burke, K., Dewey, J. F., and Kidd, W. S. F., 1974, The Tibetan Plateau: its significance for tectonics and petrology, Geol. Soc. Amer. Abs. with Prog., v. 6 , no. 7 , p. 1027-1028.

Burke, K., Dewey, J. F., and Kidd, W. S. F., 1977, World distribution of sutures; the sites of former oceans: Tectonophysics, v. 40 (1/2), p. 69-99.

Burrard, S. G., and Hayden, H. H., 1908, A sketch of the geography and geology of the Himalaya Mountains and Tibet, in The geology of the Himalaya, Pt. 4: Government of India Press, Calcutta, p. 207-308 and plates. 
Burtman, V. S., 1975, Structural geology of Variscan Tien Shan, USSR: Amer. Jour. Sci., v. 255-A, p. 157-186.

Burtman, V. S., and Gurariy, G. Z., 1973, Character of folded arcs in the Pamirs and Tien-Shan (from the geophysical data): Geotectonics, p. 90-92. Chang, Chen-fa, and Cheng, Hsi-lan, 1973, Some tectonic features of the Mt. Jolmo Lungma area, southern Tibet, China: Scientia Sinica, v. 16, no. 2, p. 257-265. Chang, C. F., et al., 1977, The geological history, tectonic zonation and origin of uplifting of the Himalayas - Peking, China.

Chang Ta, 1958, The geology of China, Peking (Trans. in U.S.J.P.R.S., item 19,$209 ; 1963 ; 623$ p.).

Chen Guoda, Chen Jiachao, Wei Bailin, Zue Jiamou, Liu Yixuan, Wen Shanji, Wei Zhouling, and Hu Huoyan, 1975, A brief review on the geotectonics of China: Scientia Geol. Sinica 1975/3, p. 205-219.

Cheng, Yu-chi, Chung Fu-dao, and Su Yun-jun, 1973, The pre-Sinian of northern and northeastern China: Acta Geol. Sinica 1973/1, p. 72-81.

Chinese Academy of Geological Sciences, 1976a, An outline of the geology of China (Compilation Group of the Geol. Map of China), Peking.

Chinese Academy of Geological Sciences, 1976b, Geological map of the People's Republic of China, Peking, scale 1:4,000,000.

Chinese Academy of Geological Sciences, 1979, Stratigraphy of China (Abstract), $49 \mathrm{p}$.

Chinese Institute of Geological Sciences, 1975, Geological map of Asia $(1: 5,000,000)$ : Map Publishing Press.

Compilation Group of the Geological Map of Asia, 1976, 1978, The geologic development and tectonic frame of Asia: Bul1. Geol. Soc. China (3) and Chinese Acad. Geol. Sci., p. 1-36.

Compilation Group of the Geological Map of China, 1976. An outline of the geology of China: Chinese Acad. of Geol. Sci., Peking, p. 1-22.

Cook, F. A., Albaugh, D. S., Brown, L. D., Kaufman, S., and 01iver, J. E., 1979, Thin-skinned tectonics in the crystalline southern Appalachians; COCORP seismic-reflection profiling of the Blue Ridge and Piedmont: Geology, v. 7, p. 563-567. 
Cook, F. A., Brown, L. D., Hatcher, R. D., Kaufman, S., and Oliver, J. E., 1979, Preliminary interpretation of COCORP reflection profiles across the Brevard zone in northeast Georgia: Abs. Spring meeting Amer. Geophys. Union. Crawford, A. R., 1974, The Indus suture line, the Himalaya, Tibet and Gondwanaland: Geol. Mag. 111, p. 369-383.

Desio, Ardito, 1979, Geologic evolution of the Karakorum, in Farah, Adut, and DeJong, Kees A. (eds.), Geodynamics of Pakistan: Geol. Survey Pakistan, Quetta, p. 111-124.

De Terra, H., 1932, Geologische Forschungen im westlichen K'un-Lun und KarakorumHimalaya: Wiss. Erg. Dr. Trinklerschen Zentralasien - Exped. 2, Reimer/Vohsen, Berlin, $218 \mathrm{~S}$.

De Terra, H., 1935, Geological studies in the north-west Himalaya between the Kashmir and Indus Valleys: Mem. Connecticut Acad. Arts Sci., no. 8, p. 18-76. Dewey, J. F., 1977, Suture zone complexities: a review: Tectonophysics, v. 40, p. 53-67.

Dewey, J. F., and Burke, K. C. A., 1973, Tibetan Variscan, and Precambrian basement reactivation: products of continental collision: Jour. Geology, v. 81 , p. 683-692.

Duan Xinhua, and Zao Hong, 1979, Discussions on the Ailaoshan-Tengtiaome fracture - a geosuture: Mimeographed handout, Geology Bureau, Yunnan Province, $9 \mathrm{p}$.

Farah, Abul, and DeJong, Kees A. (eds.), 1979, Geodynamics of Pakistan: Geol. Survey Pakistan, Quetta.

Frank, W., Gansser, A., and Trommsdorff, V., 1977, Geological observations in the Ladakh adea (Himalayas), a preliminary report: Schweiz. Mineral. Petrogr. Mitt. 57, p. 89-113.

Fuchs, G., 1975, Contributions to the geology of the north-western Himalayas: Vienna, Geol. Bundesanstalt Abhand. 32, $59 \mathrm{p}$.

Fuchs, G., 1977, The geology of the Himalayas in synoptic view, in Jest, C. (ed.), Himalaya: Sciences de la Terre: Colloques Internationaux du Centre National de la Recherche Scientifique, no. 268, Paris, p. 173-180.

Gansser, A., 1964, Geology of the Himalayas: Interscience Pub., Wiley \& Sons, London, $289 \mathrm{p}$. 
Gansser, A., 1966, The Indian Ocean and the Himalayas, a geological interpretation: Eclogae Geol. Helv., v. 59, no. 2, p. 831-848.

Gansser, A., 1973, Orogene Entwicklung in den Anden, im Himalaja und den Alpen, ein Vergleich: Eclogae Geol. Helv., v. 66, no. 1, p. 23-40. Gansser, A., 1974a, Himalaya, in Spencer, A. M. (ed.), Mesozoic-Cenozoic orogenic belts, data for orogenic studies: Geol. Soc. London Spec. Pub. 4, p. 267-278.

Gansser, A., 1974b, The ophiolitic mélange, a world-wide problem on Tethyan examples: Eclogae Geol. Helv., v. 67, no. 3, p. 479-507.

Gansser, A., 1977, The great suture zone between Himalaya and Tibet: a preliminary account, in Jest, C. (ed.), Himalaya: Sciences de la Terre: Colloques Internationaux du Centre National de la Recherche Scientifique, no. 268, Paris, p. 182-192.

Gansser, A., 1979, The Himalayas - a fascinating geological challenge: Episodes, p. 17-20.

Gansser, A., 1980, The significance of the Himalayan suture zone: Tectonophysics, v. 62, p. 37-52.

Gatinskiy, Yu. G., Rasskazov, Yu. P., Isayev, Ye. N., Kamenetskiy, A. Ye., Van Kry, Lye, Subhob, V. I., and Van Chi, Chan, 1973, Structural elements of the territory of the Democratic Republic of Vietnam: Soviet Geology, no. 9, p. 95-110.

Gobbett, D. J., 1973, Carboniferous and Permian correlation in southeast Asia: Geol. Soc. Malaysia Bu17. 6, Proc. Regional Conf. Geol. SE Asia, Kualà Lumpur, March 1972, p. 137-142.

Hamet, J., and Allegre, C. J., 1976, Rb-Sr systematics in granite from central Napal (Manaslu): significance of the 01 igocene age and high ${ }^{87} \mathrm{SR} /{ }^{86} \mathrm{SR}$ ratio in Himalayan orogeny: Geology, v. 4, p. 470-472.

Hayden, H. H., 1907, The geology of the provinces of Tsang and $\ddot{U}$ in Central Tibet: Geo1. Survey India Mem. XXXVI, Pt. 2, p. 122-201. Hennig, A., 1916, Zur Petrographie und Geologie von Südwesttibet, in Hedin, S. (ed.), Southern Tibet: Lithographic Inst. General Staff, Swedish Army, v. 5,219 p. 
Hopson, C. A., Mattison, J. M., and Pessagno, E. A., Jr., 1980, in press, Coast Range ophiolite, western California, Chap. 14, in Rubey Volume no. 1, Geotectonic development of California: Prentice-Hal1, Inc. Hou Hongfei, Wang Zengji, Wu Ruianghe, Yang Shiph, et al., 1979, The Carboniferous system of China: Chinese Acad. of Geol Sci. Stratigraphy of China (Abstract), p. 23-26.

Hsu Jen, 1976, On the discovery of a Glossopteris flora in southern Xizang and its significance in geology and palaeogeography, Scientia Geol.

Sinica, v. 4, p. 323-331.

Hsu Jen, 1978, On the palaeobotanical evidence for continental drift and Himalayan uplift: The Palaeobotanist, v. 25, p. 131-142.

Huang Chi-Ching (Huang, T. K.), 1978, An outline of the tectonic characteristics of China: Eclogae Geol. Helv., v. 71, no. 3, p. 611-635.

Huang Chi-Ching, Chang Cheng-kin, Chang Chi-meng, and Chen Guo-ming, 1965, Eugeosynclines and miogeosynclines of China and their polycyclic development: Bul1. Chin. Inst. Geol. Sci. (C: Regional and Structural Geology), 1. Huang Chi-ching, and Jiang Chun-fa, 1962, Preliminary investigation of crustal evolution from the viewpoint of polycyclicity of tectonics: Acta Geol. Sinica, v. 42, no. 2, p. 105-152.

Huang, T. K., 1945, On major tectonic forms of China: Geol. Mem. Nat1. Geol. Survey China (A), 20.

Huang, T. K., 1960a, Die geotektonischen Elemente im Aufbau Chinas, I. Tei1:

Die geotektonischen Einheiten Chinas und ihre Merkmale: Geologie (Berlin), v. 9 , no. 7 , p. 715-733.

Huang, T. K., 1960b, Die geotektonischen Elemente im Aufbau Chinas, II. Teil: Grundfragen der vergleichenden Tektonik Chinas: Geologie (Berlin), v. 9 , no. 8 , p. 841-866.

Huang, T. K., 1960c, The main characteristics of the structure of China: preliminary conclusions: Scientia Sinica, v. 9, no. 4, p. 492-544.

Huang, T. K., et a1., 1965, On eugeosynclines and miogeosynclines of China and their polycyclic development: Prof. Pap. Chin. Acad. Geol. Sci. (C), $1965 / 1$.

Huang, T. K., Jen Chi-shun, Jian Chun-fa, Chang Chih-meng, and Xu Zhi-qin, 1977, An outline of the tectonic characteristics of China: Acta Geol. Sinica 1977/2, p. 135-148. 
Hutchison, Charles S., 1973, Tectonic evolution of Sundaland: a Phanerozoic synthesis: Geol. Soc. Malaysia Bu11. 6, Proc. Regional Conf. Geol.

SE Asia, Kuala Lumpur, March 1972, p. 61-86.

Ingerso11, R. V., 1979, Evolution of the Late Cretaceous forearc basin, northern and central California: Geol. Soc. Amer. Bu11., v. 90, p. 813-826. Institute of Geomechanics, 1977, On tectonic systems: Scientia Sinica, v. 20, no. 2, p. 256-272.

Jain, A. K., Goel, R. K., and Nair, N. G. K., 1980, Implications of pre-Mesozoic orogeny in the geological evolution of the Himalaya and Indo-Gangetic plains: Tectonophysics, v. 62, p. 67-86.

Jest, C. (ed.), 1977, Himalaya: Sciences de 1a Terre, from Colloques Internationaux du Centre National de 1a Recherche Scientifique, no. 268, Paris, Dec. 7-10, 1976.

Kidd, W. S. F., 1975, Widespread late Neogene and Quaternary calc-alkaline volcanism on the Tibetan Plateau: EAS, Trans. Amer. Geophys. Union, v. 56, p. 453.

Klootwijk, C. T., 1976, The drift of the Indian subcontinent, and interpretation of recent palaeomagnetic data: Geol. Rundschau, v. 65, p. 885-909. Klootwijk, C. T., 1979, A review of palaeomagnetic data from the Indo Pakistani fragment of Gondwanaland, in Farah, Abul, and DeJong, Kees A. (eds.), Geodynamics of Pakistan: Geol. Survey Pakistan, Quetta, p. 41-80. Klootwijk, C. T., and Conaghan, P. J., submitted 1978, The extent of Greater

India: 1. Preliminary palaeomagnetic data from the Hindukush, Chitral (Pakistan): Earth Planet. Sci. Lett.

Kontorovich, A. E., Nesterov, I. I., Salmanov, F. K., Surkov, V. S., Trofimuk, A. A., and Ervye, Yu. G., 1975, Geology of oil and gas of west Siberia: Nedra, Moscow (in Russian), 679 p.

Kravchenko, K. N., 1979, Tectonic evolution of the Tien Shan, Pamir and Karakorum, in Farah, Abul, and DeJong, Kees A. (eds.), Geodynamics of Pakistan: Geol. Survey Pakistan, p. 25-40.

Krummenacher, D., 1971, Géochronometrie des roches de 1'Himalaya, in Recherches geologiques dans 1'Himalaya du Népal, region de la Thakkhola: Centre Nat1. Recherche Sci., Paris, p. 187-202.

Kusznir, N. J., and Bott, M. H. P., 1976, A thermal model of the formation of oceanic crust: Geophys. J.R. Astr. Soc., v. 47, p. 83-95. 
Lapparent, A. F. (de), 1972a, Esquisse géologique de 1'Afghanistan: Rev. Geogr.

Phys. Geo1. Dyn. 14, p. 327-343.

Lapparent, A. F. (de), 1972b, L'Afghanistan et $1 a$ dérive du continent Indien:

Rev. Geogr. Phys. Geo1. Dyn. 14, p. 449-455.

Lee, J. S., 1939, The geology of China: Murby, London.

Lee, J. S., 1973a, Crustal structure and crustal movement: Scientia Sinica,

v. 16, no. 4, p. 519-559.

Lee, J. S., 1973b, Out7ine of geomechanics: Scientific Press, Peking.

Lefort, P., 1975, Himalayas: the collided range, present knowledge of the continental arc: Amer. Jour. Sci., v. 275-A, p. 1-44.

Li Chun-Yü, 1975, Tectonic evolutions of some mountain ranges in China, as tentatively interpreted on the concept of plate tectonics: Acta Geophys. Sinica, v. 18, no. 1, p. 52-76.

Li Chun-Yü, 1978, Study of earthquake prediction on the basis of geotectonics: Acta Geophysica Sinica, v. 21, no. 1, p. 67-76.

Li Chun-Yü, Liu Xueya, Wang Quan, and Zhang Zhimeng, 1979, A tentative contribution to plate tectonics of China: Institute of Geology, Chinese Acad. of Geol. Sci., Mimeographed handout.

Li Yuntong, Lei Yizhen, Wang Daning, Sun Mengrong, Sun Ziuyu, Wang Chongyou, Weng Shije, et a1., 1979, The Tertiary system of China, in Chinese Acad. Geol. Sci. Stratigraphy of China (Abstract), p. 42-45.

Li Zhi-yi, Cai Wen-bo, Ding Meng- Tin, Xu Hao-min, and Wang Yi-peng, 1974, A note of the seismogeologic features in China: Scientia Geol. Sinica, $1974 / 4$, p. 356-370.

Ma Xingyuan, You Zhengong, Tan Yingjia, Yang Weiran, Li Dongxu, and Wu Zhengwen, 1961, Some basic problems of tectonics of China: Acta Geol. Sinica, v. 41 , no. 1 .

Maung Thien, 1973, A preliminary synthesis of the geological evolution of Burma with reference to the tectonic development of southeast Asia: Geol. Soc. Malaysia Bu11. 6, Proc. Regional Conf. Geol. SE Asia, Kuala Lumpur, March 1972, p. 84-116.

McCulloch, M. T., Gregory, R. T., Wasserburg, G. J., and Taylor, H. P., Jr., 1980, in press, Sm-Nd, Rb-Sr, and ${ }^{18} 0 /{ }^{16} 0$ isotopic systematics in an oceanic crustal section: evidence from the Samail ophiolite: Jour. Geophys. Res. 
McElhinney, M. W., Haile, N. S., and Crawford, A. R., 1974, Palaeomagnetic evidence shows Malay Peninsula was not a part of Gondwanaland: Nature, v. 252, p. 641-645.

Meyerhoff, A., 1978, Petroleum in Tibet and the India-Asia suture (?) zone: Jour. Petrol. Geol., v. 1, no. 2, p. 107-112.

Molnar, P., and Burke, K., 1977, Erik Norin Penrose Conf. on Tibet: Geology, v. 5, p. 461-463.

Molnar, P., and Chen Wang-ping, 1978, Evidence of Targe Cainozoic crustal shortening of Asia: Nature, v. 273, p. 218-220.

Molnar, P., Chen, W. P., Fitch, T. J., Tapponnier, P., Warsi, W. E. K, and Wu, F. T., 1977, Structure and tectonics of the Himalaya: a brief summary of relevant geophysical observations, in Jest, C. (ed.), Himalaya: Sciences de 1a Terre: Colloques Internationaux du Centre National de la Recherche Scientifique, no. 268, Paris, p. 269-294. Molnar, P., Fitch, T. J., and Wu, F. T., 1973, Fault plane solutions of shallow earthquakes and contemporary tectonics in Asia: Earth Planet. Sci. Lett., v. 19, p. 101-112.

Molnar, P., and Tapponnier, P., 1975, Cenozoic tectonics of Asia: effects of a continental collision: Science, v. 189, p. 419-426.

Molnar, P., and Tapponnier, P., 1977, The relation of the tectonics of eastern China to the India-Eurasia collision: an application of slip-line field theory to large scale continental tectonics: Geology, v. 5, p. 212-216. Molnar, P., and Tapponnier, P., 1978, Active tectonics of Tibet: Jour. Geophys. Res., v. 83, p. 5361-5375.

Moore, J. G., and Lockwood, J. P., 1978, Spreading cracks in pillow lava: Jour. Geology, v. 86, p. 661-671.

Moore, J. G., and Schilling, J. G., 1973, Vesicles, water, and sulfur in Reykjanes Ridge basalts: Contr. Minera1. Petrol., v. 41, p. 105-118. Mt. Jolmo Lungma Area Scientific Expedition, 1966-1968, 3 volumes. Mu An-Tse, Wen Shi-Hsuan, Wang Yi-Kang, Chang Ping-Kao, and Yin Chi-Hsiang, 1973, Stratigraphy of the Mount Jolmo Lungma region in southern Tibet, China: Scientia Sinica, v. 16, no. 1, p. 96-111. Narain, Hari, 1980, Overview of some recent geophysical investigations in Himalaya: Tectonophysics, v. 62, p. 99-111. 
Norin, E., 1941, Geologic reconnaissances in the Chinese Tien Shan, in Reports from Sci. Exped. to NW provinces of China under S. Hedin, Pt. III, Geology 6, Aktiebolaget Thule, Stockholm.

Norin, E., 1946, Geological explorations in western Tibet: Sino-Swedish Exped. Pub. 29, Aktiebolaget Thule, Stockholm, $214 \mathrm{p}$.

Norin, E., 1974, The Sub-Cenomanian surface of denudation and the Upper Cretaceous sedimentary sequence in western Tibet: Riv. Ital Stratigr. Paleontol., Mem. 14, Milano, p. 359-374.

Norin, E., 1976, The "Black Slates" formations in the Pamirs, Karakoram and western Tibet, in Geotettonica delle zone orogeniche del Kashmir Himalaya Karakorum-Hindu, Kush-Pamir: Conv. Lincei, Atti 21, Accad. naz. Lincei, Roma, p. 245-264.

Norin, E., 1979, The relationshiops between the Tibetan Platform and the Tarim Basin: Bull. Geol. Instit., Univ. Uppsala, N.S., v. 8, p. 17-34. Norton, I., and Molnar, P., 1977, Implications of a revised fit between Australia and Antarctica for the evolution of the Eastern Indian Ocean: Nature, v. 267, p. 338-340.

Pallister, J. S., and Hopson, C. A., submitted 1980, Samail ophiolite plutonic suite: I. field relations, phase variation, cryptic variation and layering: Jour. Geophys. Res.

Pecher, A., and Lefort, P., 1977, Origin and significance of the Lesser Himalaya Augen gneisses, in Jest, C. (ed.), Himalaya: Sciences de la Terre:

Colloques Internationaux du Centre National de la Recherche Scientifique, no. 268, Paris, p. 319-330.

People's Republic of China, 1975a, Geologic map of Asia, 1:5,000,000; 20 sheets. People's Republic of China, 1975b, Tectonic system map of China, 1:4,000,000;

1 sheet.

People's Republic of China, 1976, Geologic map of China, 1:4,000,000; 1 sheet. Pessagno, E. A., Jr., 1974, Radiolarian zonation and stratigraphy of the Upper Cretaceous portion of the Great Valley sequence, California Coast Ranges: Micropaleontology, Spec. Pap. 1. 
Pessagno, E. A., Jr., 1977a, Upper Jurassic radiolaria and radiolarian biostratigraphy of the California Coast Ranges: Micropaleontology, v. 22, no. 1, p. 56-113.

Pessagno, E. A., Jr., 1977b, Lower Cretaceous radiolarian biostratigraphy of the Great Valley sequence and Franciscan complex, California Coast Ranges: Cushman Found. Foram. Res., Spec. Pub. no. 15, p. 1-87.

Pessagno, E. A., Jr., Finch, W., and Abbott, P. L., 1979, Upper Triassic radiolaria from the San Hipolito formation, Baja California: Micropaleontology, v. 25, no. 2, p. 160-197.

Powe11, C. MCA., 1979, A speculative tectonic history of Pakistan and surroundings: some constraints from the Indian Ocean, in Farah, Abu1, and DeJong, Kees A. (eds.), Geodynamics of Pakistan: Geol. Survey Pakistan, Quetta, p. 6-24.

Powe11, C. McA., and Conaghan, P. J., 1973, Plate tectonics and the Himalayas: Earth Planet. Sci. Lett., v. 20, p. 1-12.

Powe11, C. McA., and Conaghan, P. J., 1975, Tectonic models of the Tibetan P1ateau: Geology, v. 3, no. 12, p. 727-731.

Qureshy, M. N., Venkatachalam, S., and Subrahmanyam, C., 1974, Vertical tectonics in the middle Himalayas: an appraisal from recent gravity data: Geo1. Soc. Amer. Bu11., v. 85, p. 921-926.

Sengör, A. M. C., 1979, Mid-Mesozoic closure of Permo-Triassic Tethys and its implications: Nature, v. 279, p. 590-593.

Sengör, A. M. C., and Kidd, W. S. F., 1979, Post-collisional tectonics of the Turkish-Iranian Plateau and a comparison with Tibet: Tectonophysics, v. 55, p. $361-376$.

Shah, S. K., 1977, Indus ophiolite belt and the tectonic setting of the Malla Johar-Kiogad exotics in Himalaya, in Jest, C., (ed.), Himalaya: Sciences de 1a Terre: Colloques Internationaux du Centre National de la Recherche Scientifique, no. 268, Paris, p. 369-378.

Shi Zhen-liang, Huan Wen-lin, Wu Huang-ring, and Cao Xin-1ing, 1973, On the intensive seismic activity in China and its relation to plate tectonics: Scientia Geol. Sinica, 1973/4, p. 281-293. 
Sinha, A. K., and Bagdasarian, 1977, Potassium-Argon dating of some magmatic and metamorphic rocks from Tethyan and lesser zones of Kumaun and Garhwal Indian Himalaya, in Jest, C. (ed.), Himalaya: Sciences de la Terre:

Colloques Internationaux du Centre National de la Recherche Scientifique, no. 268, Paris, p. 387-394.

Sleep, N. H., 1975, Formation of oceanic crust: some thermal constraints: Jour. Geophys. Res., v. 80, p. 4037-4042.

Stille, H., 1924, Grundfragen der vergleichenden tektonik: Borntraeger, Berlin. Stöckl in, J., 1968, Structural history and tectonics of Iran: a review: Amer. Assoc. Petrol. Geol. Bu11., v. 52, p. 1229-1258.

Stöcklin, J., 1974, Possible ancient continental margins in Iran, in Burk, C. A., and Drake, C. L. (eds.), The geology of the continental margins: SpringerVerlag, Berlin, p. 873-887.

Stöckl in, J., 1977, Structural correlation of the Alpine ranges between Iran and central Asia: Mém. h. sér. Soc. Géol. France, no. 8, p. 333-353.

Stöckl in, J., and Nabavi, M. H., 1973, Tectonic map of Iran: Geol. Survey Iran, Tehran.

Tahirkheli, R. A. Khan, Mattauer, M., Proust, F., and Tapponnier, P., 1979, The India Eurasia suture zone in northern Pakistan: Synthesis and interpretation of recent data at plate scale, in Farah, Abul, and DeJong, Kees A. (eds.), Geodynamics of Pakistan: Geol. Survey Pakistan, Quetta, p. 125-130.

Tapponnier, P., and Molnar, P., 1976, Slip-line field theory and large scale continental tectonics: Nature, v. 264, p. 319-324.

Tapponnier, P., and Molnar, P., 1977, Active faulting and Cenozoic tectonics in China: Jour. Geophys. Res., v. 82, p. 2905-2930.

Tater, J. M. (ed.), 1980, The Alpine-Himalayan region: Tectonophysics Special Issue, v. 62, $164 \mathrm{p}$.

Teng Chi-tung, Chang yu-ming, Hsu Kwei-lin, and Fan Fu-tian, 1979, On the tectonic stress field in China and its relation to plate movement: Physics of Earth and Planet. Interiors, no. 18, p. 257-273.

Teng Chi-wen et al., 1974, Deep reflected waves and the structure of the earth crust of the eastern part of Tsaidam Basin: Acta Geophys. Sinica, v. 17, no. 2 , p. 122-135. 
Teng Chi-wen, Feng Chi-fen, Li Kin-sun, Chen Hsueh-po, Wen Kun-ti, Chang Kai-ju, Hsing Cheng-chun et al., 1974, Crustal structure of the central part of north China plain and the Hsintai earthquake (I): Acta Geophys. Sinica, v. 17, no. 4, p. 255-271.

Terman, M. J., 1974, Tectonic map of China and Mongolia, 1:5,000,000: Geol. Soc. Amer., Boulder.

Thakur, V. C., 1977, Divergent isograds of metamorphism in some part of higher Himalaya zone, in Jest, C. (ed.), Himalaya: Sciences de la Terre: Colloques Internationaux du Centre National de la Recherche Scientifique, no. 268, Paris, p. 433-442.

Thakur, V. C., 1980, Tectonophysics of the central crystallines of Western Himalaya: Tectonophysics, v. 62, p. 141-154.

Tilton, G. R., Hopson, C. A., and Wright, J. E., 1980, in press, Uranium-lead isotopic ages of the Samail ophiolite, Sultanate of Oman, and tectonic implications: Jour. Geophys. Res.

Toksöz, M. N., and Bird, P., 1977a, Formation and evolution of marginal basins and continental plateaus, in Talwani, M., and Pitman, W. C. III (eds.), Island arcs, deep sea trenches, and back-arc basins: Amer. Geophys. Union Maurice Ewing Ser. 1, p. 379-394.

Toksöz, M. N., and Bird, P., 1977b, Tectonophysics of the continuing Himalayan orogeny, in Jest, C. (ed.), Himalaya: Sciences de 1a Terre: Colloques Internationaux du Centre National de la Recherche Scientifique, no. 268, Paris, p. 443-448.

Tsui Sheng-chen, Yang Chen-sheng, Chou Nan-suo, Lee Chi-chau, and Ke Hsiau-hung, 1977, Palaeotectonic systems of the Yen-Liao and its adjacent areas, China: Acta Geol. Sinica, no. 2, p. 149-159.

Veevers, J. J., Powe11, C. McA., and Johnson, B. D., 1975, Greater India's place in Gondwanaland and in Asia: Earth Planet. Sci. Lett., v. 27, p. 383-387.

Wang Quan, and Kiu Xue-ya, 1976, Paleo-oceanic crust of the Chilienshan Region, western China and its tectonic significance: Scientia Geol. Sinica, no. 1, p. 42-55.

Wang Yipen, 1979, Intraplate earthquake and Meso-Cenozoic stress field in China: Seismology and Geology, v. 1, no. 3, p. 1-11. 
Warsi, W. E. K., and Molnar, P., 1977, Gravity anomalies and plate tectonics in the Himalaya, in Jest, C. (ed.), Himalaya: Sciences de la Terre:

Colloques Internationaux du Centre National de la Recherche Scientifique, no. 268, Paris, p. 463-478.

Wu Haoruo,, Wang Dongan, and Wang Lianchen, 1977, The Cretaceous of Laze-

Jiangze district, southern Xizang: Scientia Geol. Sinica, v. 3, p. 250-262. Xiangyuan Zhu, Chung Liu, Sujuan Ye, and Jinlu Lin, 1977, Fide Molnar and Chen, 1978, TITLE UNKNOWN, Scientia Geol. Sinica, no. 1, 44.

Xiao Xuchang, Chen Guoming, and Zu Zhizhi, 1978, A preliminary study of the tectonics of ancient ophiolites in the Qilian Mountain, northwest China: Acta Geol. Sinica, no. 4, p. 281-296.

Xu Chia Wei, 1979 unpublished, The strike-slip displacement along Tanlu fracture and its significance in terms of geology and the search for minerals. Yin Jixiang, and Guo Shizeng, 1976, On the discovery of the stratigraphy of Gondwana facies in northern slope of the Qomolangma Feng in southern Xizang, China: Scientia Geol. Sinica, no. 4, p. 323-332.

Zhang Zhimeng, 1979, Relationship between intraplate earthquakes and interplate earthquakes in China and adjacent regions: Seismology and Geology, v. 1, no. 3 , p. 12-24.

Zhang Zhimeng, and Jin Meng, 1979, Two kinds of mélange and their tectonic significance in Ziangcheng-Derong area, southwestern Sichuan: Scientia Geol. Sinica, no. 7, p. 205-216.

Zhang, Z., and Jin., M., 1980, in press, Ophiolitic melange along the Jinsha River-Red River suture: International Ophiolite Symposium, Nicosia, Cyprus.

Zonenshain, L. P., 1973, The evolution of Central Asiatic geosynclines through sea-floor spreading: Tectonophysics, v. 19, p. 213-232. 


\section{LIST OF ILLUSTRATIONS}

Fig. Ta. Tectonic map of China and adjacent areas.

1b. Explanation for tectonic map.

Fig. 2. Index map with some of the more important names.

Fig. 3a. Distribution of Triassic (Indonesian) and Jurassic-Cretaceous (Yenshanian) intrusives and major onshore sedimentary basins. 3b. Explanation for 3a.

Fig. 4. Stratigraphy of Tethys Himalayas - Region I.

Fig. 5. Explanation for stratigraphic columns.

Fig. 6. Stratigraphy of S. Tibetan Plateau or Region II - Subregion II .

Fig. 7. Stratigraphy of S. Tibetan Plateau or Subregion $\mathrm{II}_{2}$ and $\mathrm{III}_{3}$.

Fig. 8. Stratigraphy of Central Tibetan Plateau - Subregion III $_{2}$.

Fig. 9. Geologic map of Yaluzangbu suture by Tibet Bureau of Geology, 1979.

(a) west half

(b) east half

Fig. 10. Geology of the surroundings of Rikaze (Shigatse).

Fig. 11. Cross section of the ophiolitic complex near Rikaze (Shigatse) the Xia Lu village section.

Fig. 12. Sketch summarizing the stratigraphy of Fig. 6 .

Fig. 13. Geologic sketch map of the Ailao Shan Mountains.

Fig. 14. Stratigraphic columns for SW Yunnan.

Fig. 15. Scanning electron microscope (SEM) photographs of selected radiolarians extracted from chert at the base of the Xialu section $22 \mathrm{~km}$ southeast of Rikaze (79APr109B), from a chert pod associated with Triassic rocks $95 \mathrm{~km}$ west of Rikaze (79APr 112), and from Jurassic-Cretaceous siltstone (79APr 115) and a chert knocker (79APr116) along the Lhasa-Rikaze highway approximately $40 \mathrm{~km}$ southeast of Jiangzi. SEM photographs by Linda Barry and B. L. Murchey-Setnicker; identifications by Murchey-Setnicker and D. L. Jones.

1) Thanarla pulchra (Squinabol); X 200; 79APr116; known range: Cenomanian of California, Cenomanian to Turonian of Romania.

2) Thanarla conica (Aliev); X 300; 79APr109B; known range: Valanginian to Aptian.

3) Xitus sp.; X 200; 79APr112; known range: Upper Jurassic?, Cretaceous.

4) Unnamed nassellariinid; $X$ 300; 79APri09B.

5) Unnamed nassellariinid; $X$ 200; 79APr $112 B$. 
Fig. 15. (Continued)

6) Acaeniotyle sp. aff. A. umbilicata (Rüst); X 150;

79APrl12B; known range of $A$. umbilicata: Berriasian (or older) to Albian.

7) Xitus sp.; X 200; 79APr 116; known range: Upper Jurassic?, Cretaceous.

8) Pseudoeucyrtis micropora (Squinabol); X 200; 79APr112; known range: Valanginian to Barremian.

9) Zifondium sp.; X 200; 79APr112B; known range: Albian to Cenomanian.

10) Thanarla lacrimula (Foreman); X 200; 79APr115A; known range: VaTanginian to Aptian.

11) Acanthocircus n.s., sp. aff. A. multidentatus (Squinabol); $X 300 ; 79 A P r 112 B$; known range of $\underline{A}$. multidentatus: Albian.

Fig. 16. Large knocker of Cretaceous radiolarian ribbon chert in graywackeargillite mélange at highway marker km 204 west of Lhasa (locality " $x$ " on Figures $9 a$ and $9 b$ ).

Fig. 17. Thick marine section of probable Cretaceous sandstone and shale (J-K unit) dipping south apparently beneath mêlange unit shown in Figure 15. Location along highway about $20 \mathrm{~km}$ west of locality " $x$ " on Figures 9a and 9b.

Fig. 18. View west of serpentinite mélange $73 \mathrm{~km}$ west of Shigatse.

Fig. 19. Massive pillow basalt at north end of Xia Lu village ophiolite section (Fig. 11). Bedding dips approximately $70^{\circ}$ north (to the right).

Fig. 20. View west of faulted anticline overturned to south on outskirts of Rikaze. Sequence consists of volcanogenic sandstone and shale with minor 7 imestone of the Cretaceous Rikaze Formation. Exposure is about $50 \mathrm{~m}$ high.

Fig. 21. The Yangbajing geothermal area on the Tibetan Plateau approximately $50 \mathrm{~km}$ northwest of Lhasa. Geothermal resources here are under active development for electric power generation (note drill rig in center of view). The valley floor is at 14,300 m elevation and the mountain crest in background averages about $6,000 \mathrm{~m}$.

Fig. 22. The American Plate Tectonics Delegation and their Chinese hosts in Tibet at pass about 5,000 $\mathrm{m}$ high along the Lhasa-Rikaze highway. View looking north across the Tsangpo River valley to the southern margin of the Tibetan Plateau.

Fig. 23. View southeast along the Red River valley in Yunnan Province. Yuan-Jang is in the right middle distance and the Red River fault is located along the base of the ridge across the valley. 


\section{LIST OF TABLES}

Table 1. Classification of deep fractures according to depth, after Huang Chi-ching, 1978.

Table 2. Platform characteristics, abstracted from T. K. Huang, 1960.

Table 3. List of the principal depth fractures in China, after Huang Chi-ching, 1978.

Table 4. Stratigraphy east Central Tibetan Plateau - Subregion III .

Table 5. Stratigraphy east Central Tibetan Plateau - Subregion III .

Table 6. Stratigraphy west Central Tibetan Plateau - Subregion $\mathrm{III}_{3}$.

Table 7. Stratigraphy of north Tibetan Plateau, Kekexili - Region IV. 


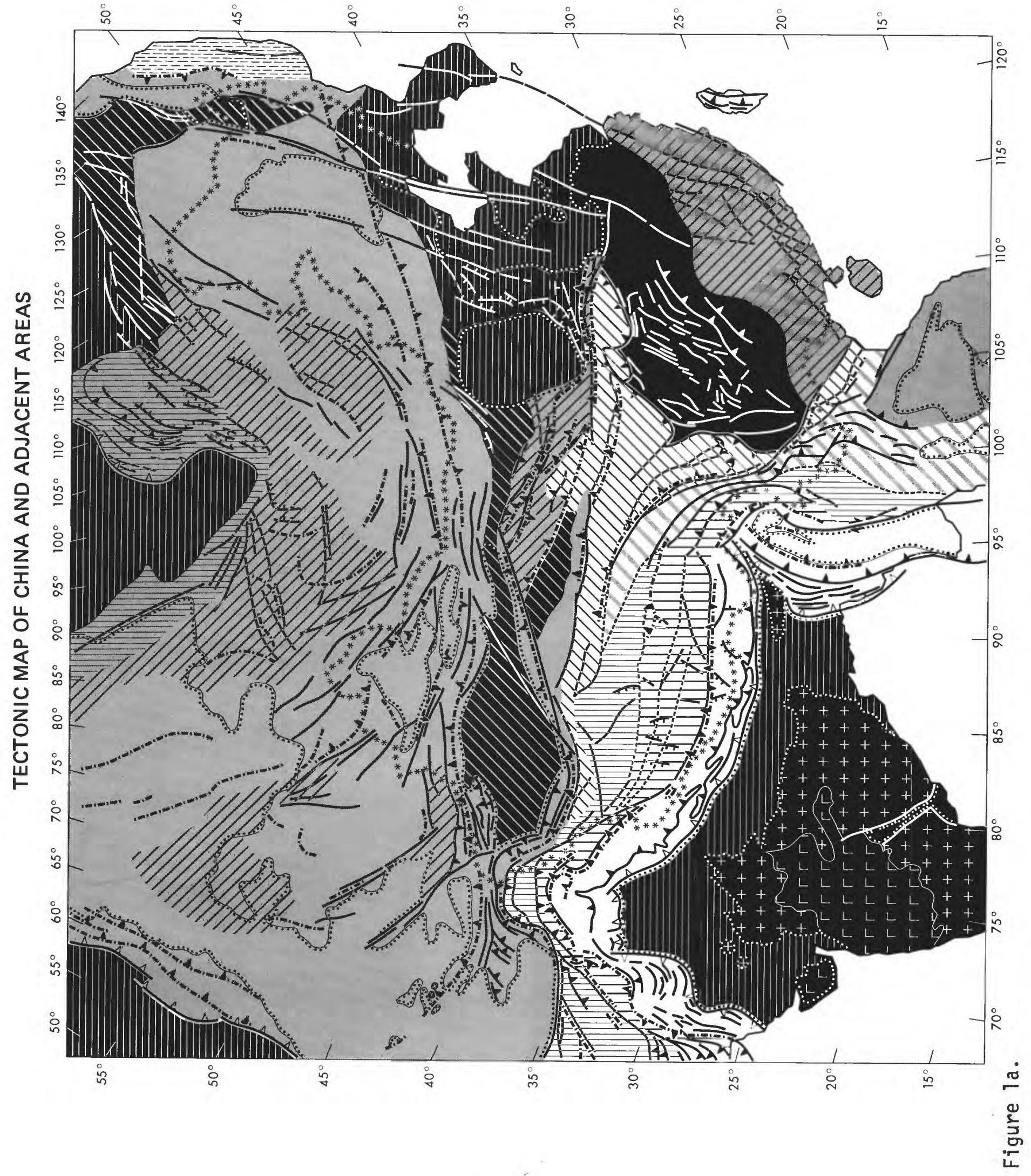



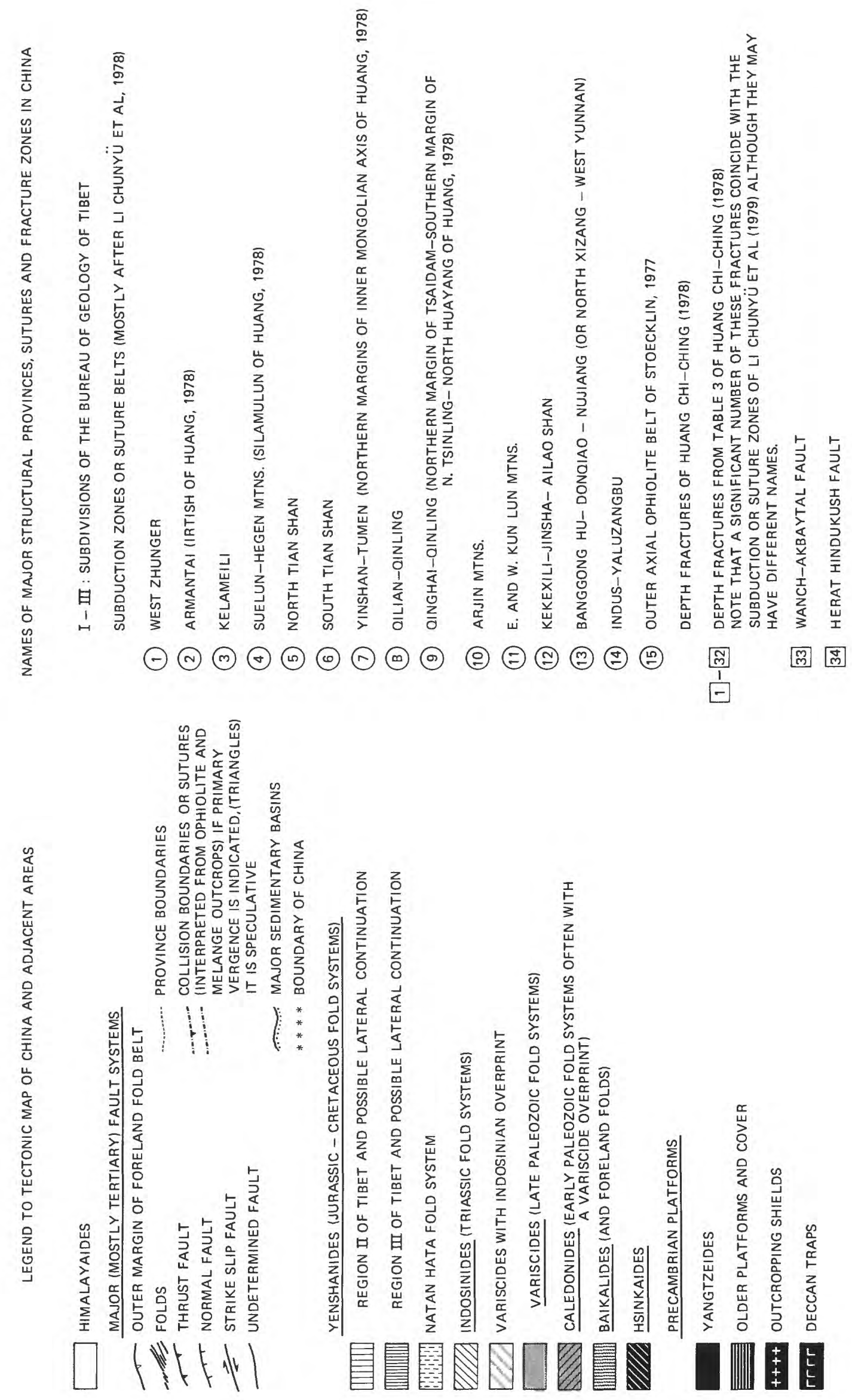


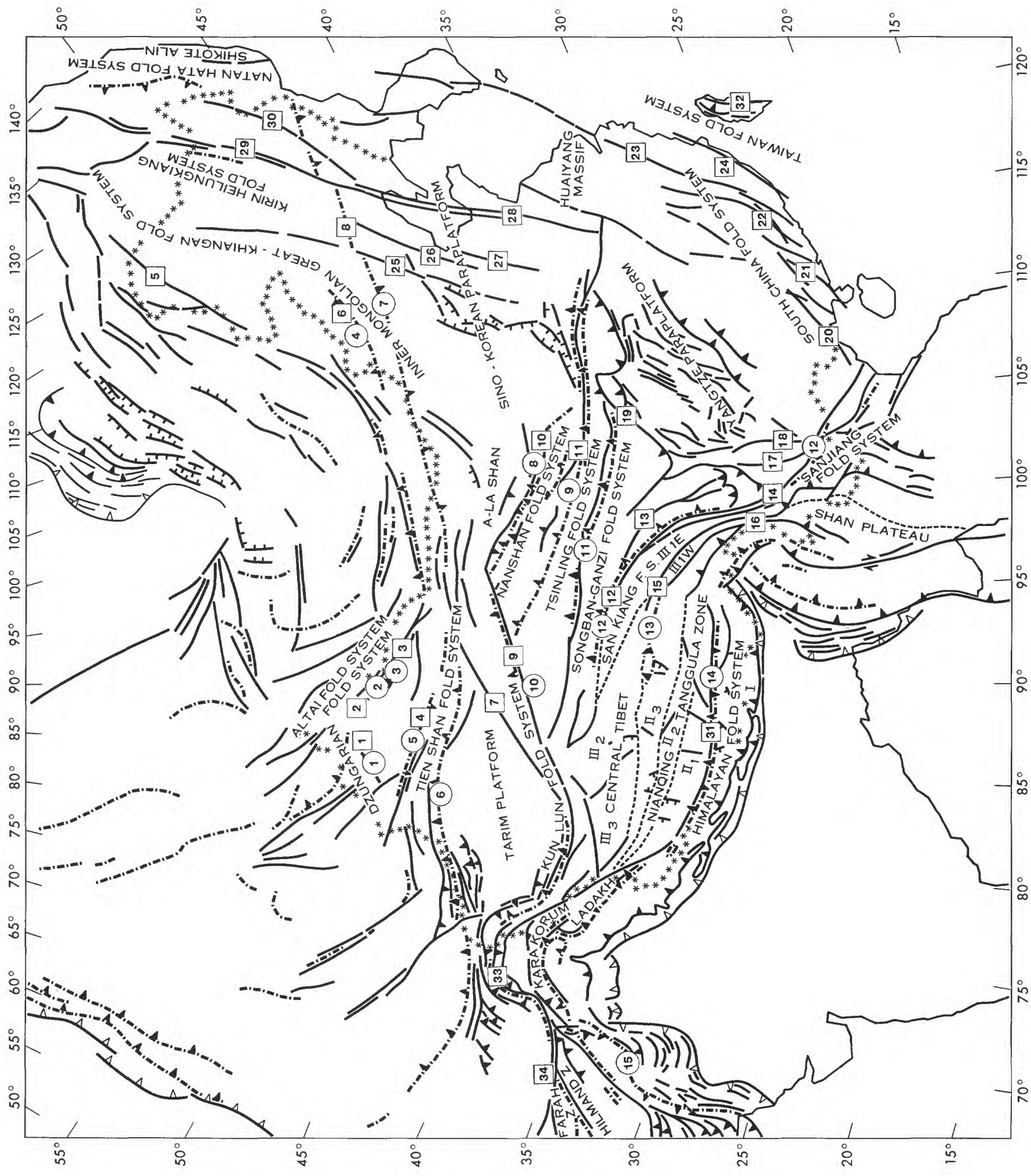

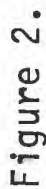




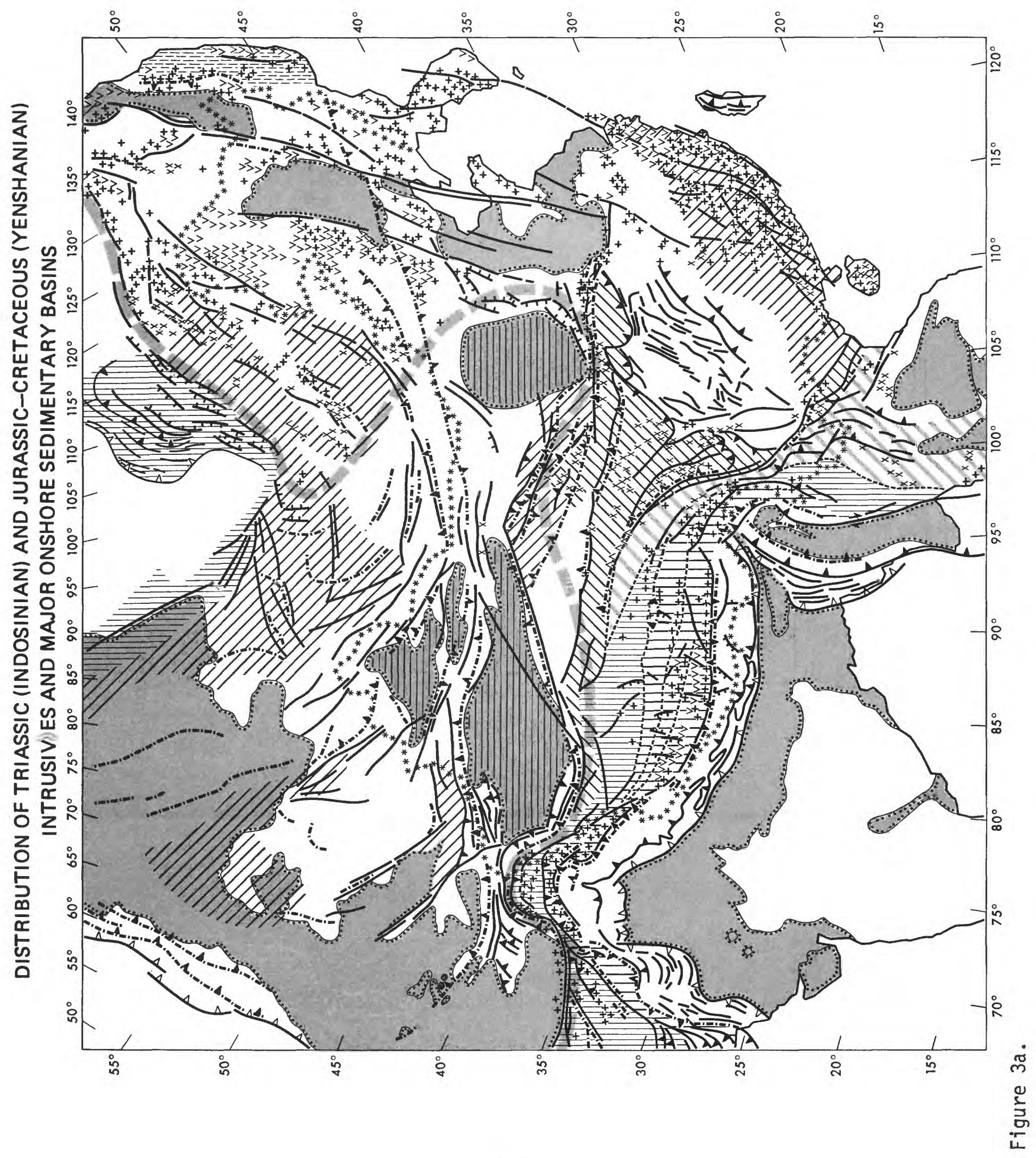


LEGEND: DISTRIBUTION OF TRIASSIC (INDOSINIAN) AND JURASSIC-CRETACEOUS (YENSHANIAN) INTRUSIV ES AND MAJOR ONSHORE SEDIMENTARY BASINS (INDOSENIAN) MAJOR (MOSTLY TERTIARY) FAULT SYSTEMS

OUTER MARGIN OF FORELAND FOLD BELT FOLDS

THRUST FAULT

NORMAL FAULT

STRIKE SLIP FAULT

UNDETERMINED FAULT

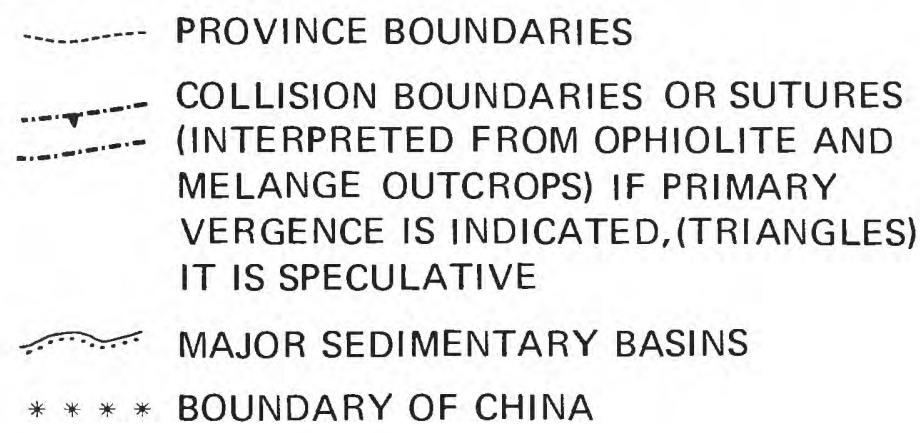

YENSHANIDES (JURASSIC - CRETACEOUS FOLD SYSTEMS)

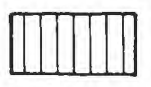

REGION II OF TIBET AND POSSIBLE LATERAL CONTINUATION

REGION III OF TIBET AND POSSIBLE LATERAL CONTINUATION

NATAN HATA FOLD SYSTEM

INDOSINIDES (TRIASSIC FOLD SYSTEMS)

VARISCIDES WITH INDOSINIAN OVERPRINT

$\vee \vee \vee V$

JURASSIC - CRETACEOUS VOLCANICS

+++ JURASSIC AND CRETACEOUS GRANITIC INTRUSIONS

$\triangle \wedge \wedge \wedge$ TRIASSIC VOLCANICS

$x \times x X$ TRIASSIC GRANITIC INTRUSIONS

LANDWARD BOUNDARY OF MESOZOIC FELSIC IGNEOUS ROCKS

MAJOR ONSHORE SEDIMENTARY BASINS

CHINESE TYPE BASINS OF BALLY AND SNELSON (1980)

Figure $3 b$. 
TETHYS HIMALAYAS - REGION I

S. PART OF MOUNT JOLMO LUNGMA REGION

AFTER MU AN-TZE, ET AL, 1973

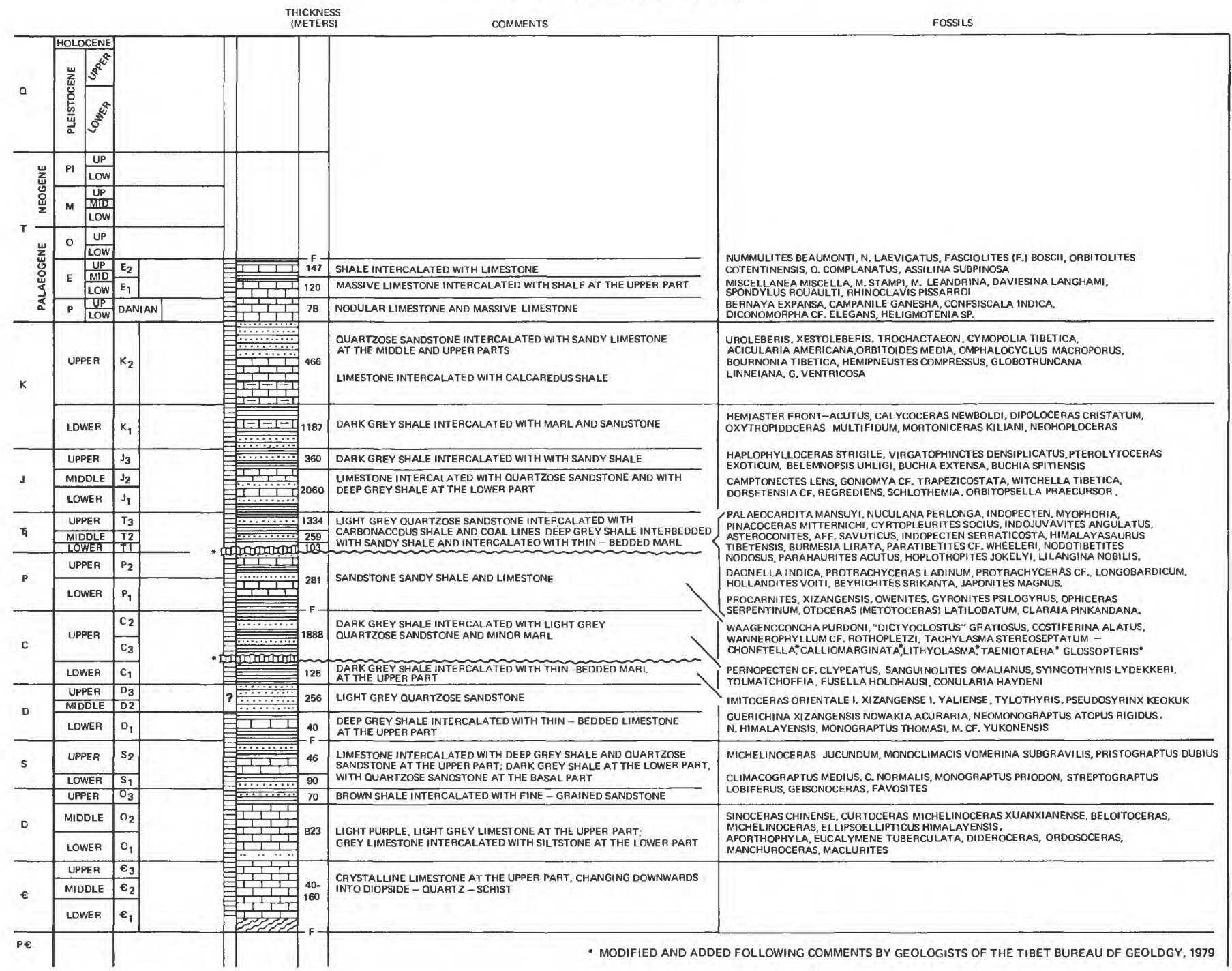

Figure 4. 


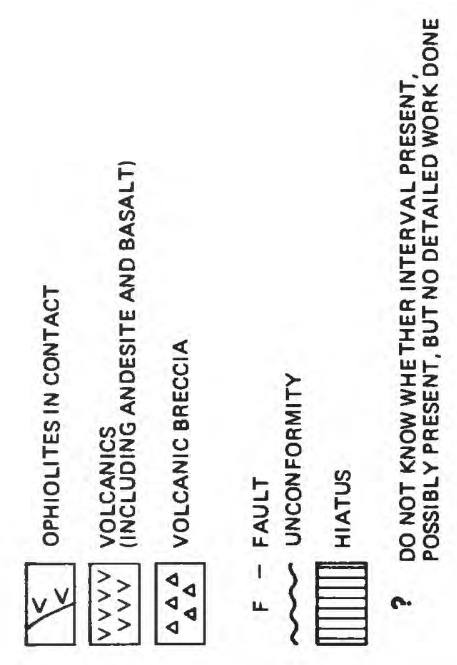

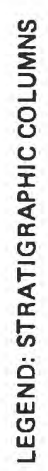
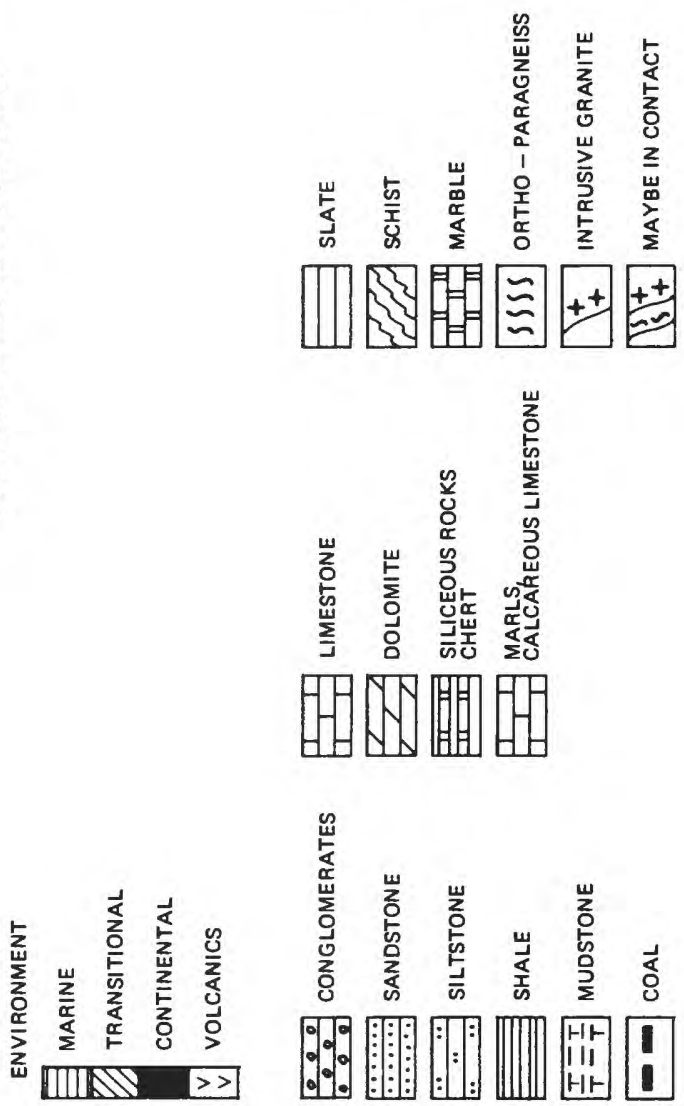

ஸ்
0
$\frac{2}{3}$
문 


\section{S. TIBETAN PLATEAU OR NIANQING TANGGULA REGION II BY TIBET BUREAU OF GEOLOGY, 1979}

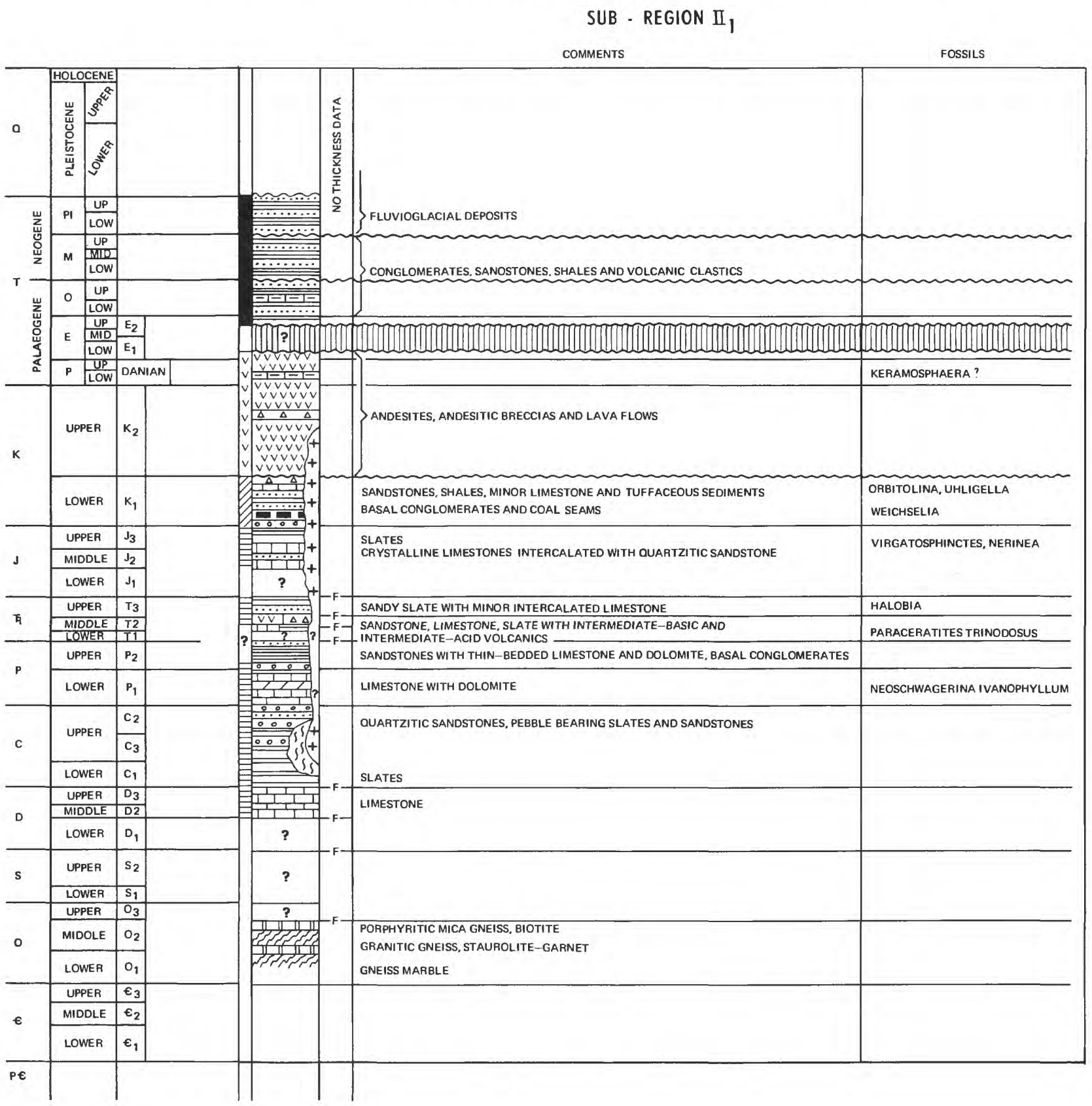

\section{Figure 6.}




\section{S. TIBETAN PLATEAU OR NIANQING TANGGULA REGION II BY TIBET BUREAU OF GEOLOGY, 1979}
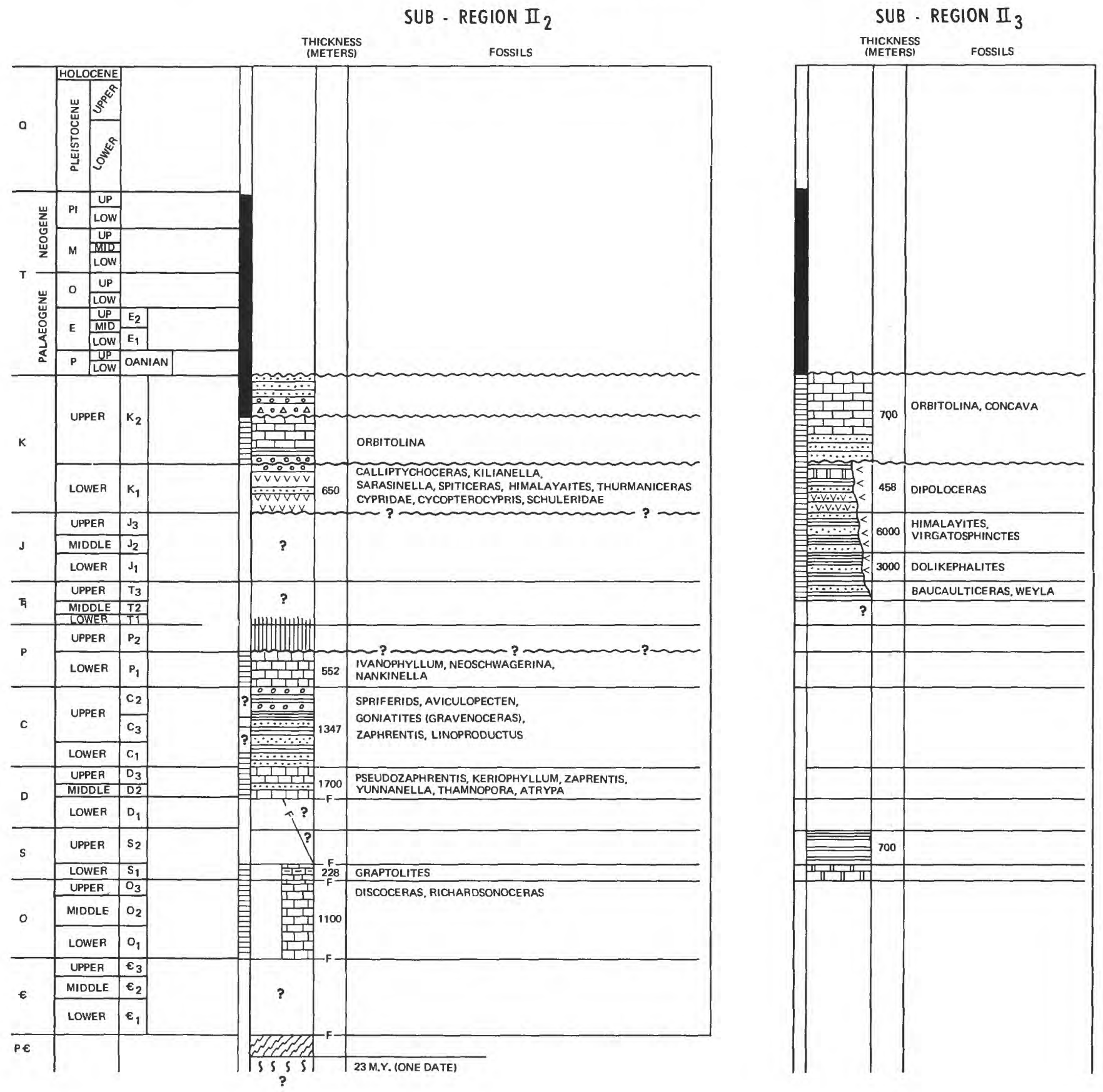

Figure 7. 


\section{CENTRAL TIBETAN PLATEAU}

BY TIBET BUREAU OF GEOLOGY, 1979

\section{SUB - REGION III 2}

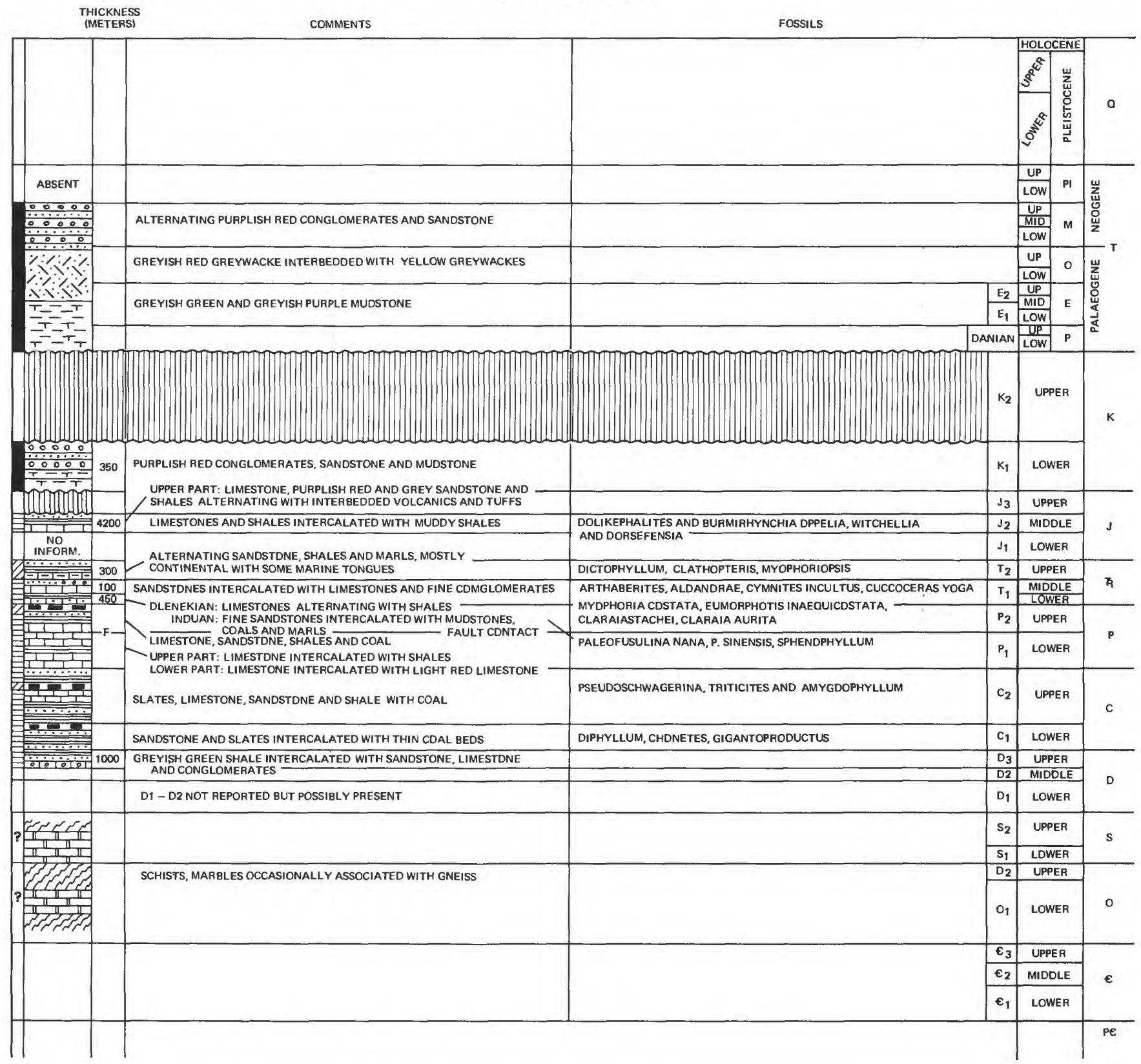

Figure 8. 


\section{YALUZANGBU (TSANGPO) SUTURE}

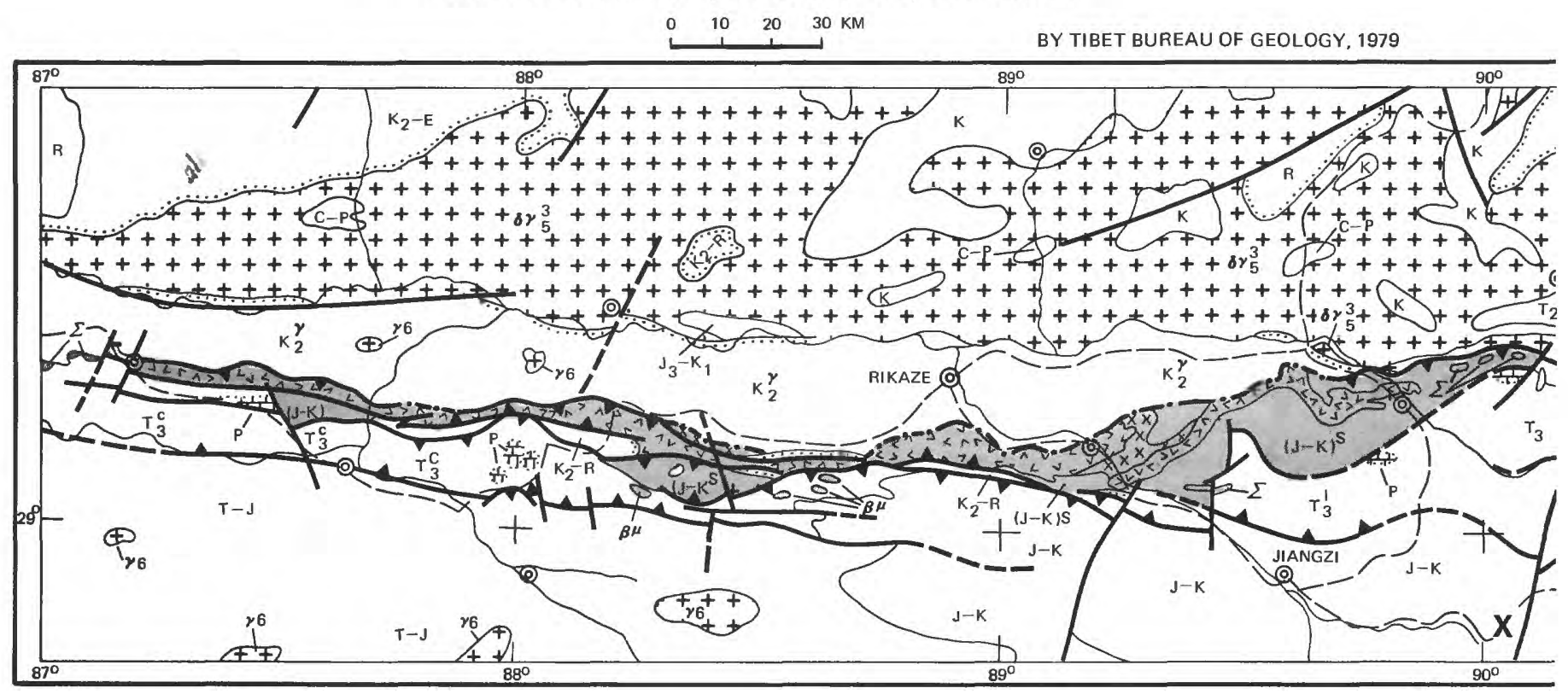

\footnotetext{
NEOGENE N ANDESITE, VOLCANIC CLASTICS AND SANDSTONE CONGLOMERATE

PALAEOGENE E INTERMEDIATE VOLCANIC CLASTICS AND CONGLOMERATE

UNDIVIDED R INTERMEDIATE VOLCANIC ROCKS AND CONGLOMERATIC SANDSTONE

$R^{\prime}$ SANDSTONE AND SHALE, WITH CONGLOMERATE AND CONGLOMERATIC SANDSTONE AT ITS BASE AND COAL SEAMS IN THE LOWER PART

CRETACEOU

UPPER SERIES K K ALTERNATIONS OF SANDSTONE AND SHALE WITH MINOR LIMESTONE, BASAL CONGLOMERATE AND UNDIVIDED $\quad K$ VOLCANIC ROCKS AND VOLCANIC CLASTICS

JURASSIC $J_{3}-K_{1}$ SANDY SHALE, LIMESTONE INTERCALATED WITH INTERMEDIATE TO BASIC VOLCANICS (ALONG TO ACID VOLCANIC CLASTIS AND QUARTZITE WITH THIN COAL BEDS

CRETACEOUS $J \rightarrow K$ SHALE, SANDSTONE AND MINOR LIMESTONE INTERCALATED WITH FELDSPATHIC QUARTZ SANDSTONE AND INTERMEDIATE TO BASIC VOLCANICS UPPER AND MIDDLE
JURASSIC $\quad J_{2-3}^{d}$ CRYSTALLINE LIMESTONE, MARBLE INTERCALATED WITH QUARTZITIC SANDSTONE IN THE TOP SLATE

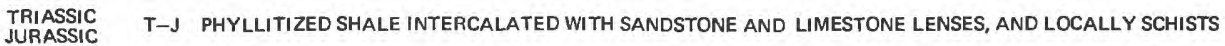

TRIASSIC

$T_{3}^{Y}$ SANDY SLATE INTERCALATED WITH LIMESTONE AND MARBLE OR METAMORPHOSED VOLCANICS

T UPPER PART: SHALE, LIMESTONE WITH MARL
3 LOWER PART: SLATE, SCHIST AND MARBLE T ALTERNATIONS OF SANDSTONE, SHALE AND SLATE INTERCALATED WITH MINOR LIMESTONE
3 (FLYSCH - TURBIDITE IN TRENCH)

$T_{3}^{c}$ SHALE INTERCALATED WITH SANDSTONE AND THIN BEDDED AND LENTICULAR MARL, CONTAINING

MIDDLE SERIES T $T_{2}^{d}$ SANDSTONE, LIMESTONE, SLATE AND INTERMEDIATE - BASIC AND INTERMEDIATE - ACID VOLCANICS $(J-K)$ S OPHIOLITE SUITE WITH BASIC VOLCANICS, RADIOLARIA - BEARING SILICEOUS ROCKS AND METAMORPHOSED ABYSSAL ARGILLACEOUS DEPOSITS IN ITS UPPER PART
}

Figure 9a. 


\section{YALUZANGBU (TSANGPO) SUTURE}

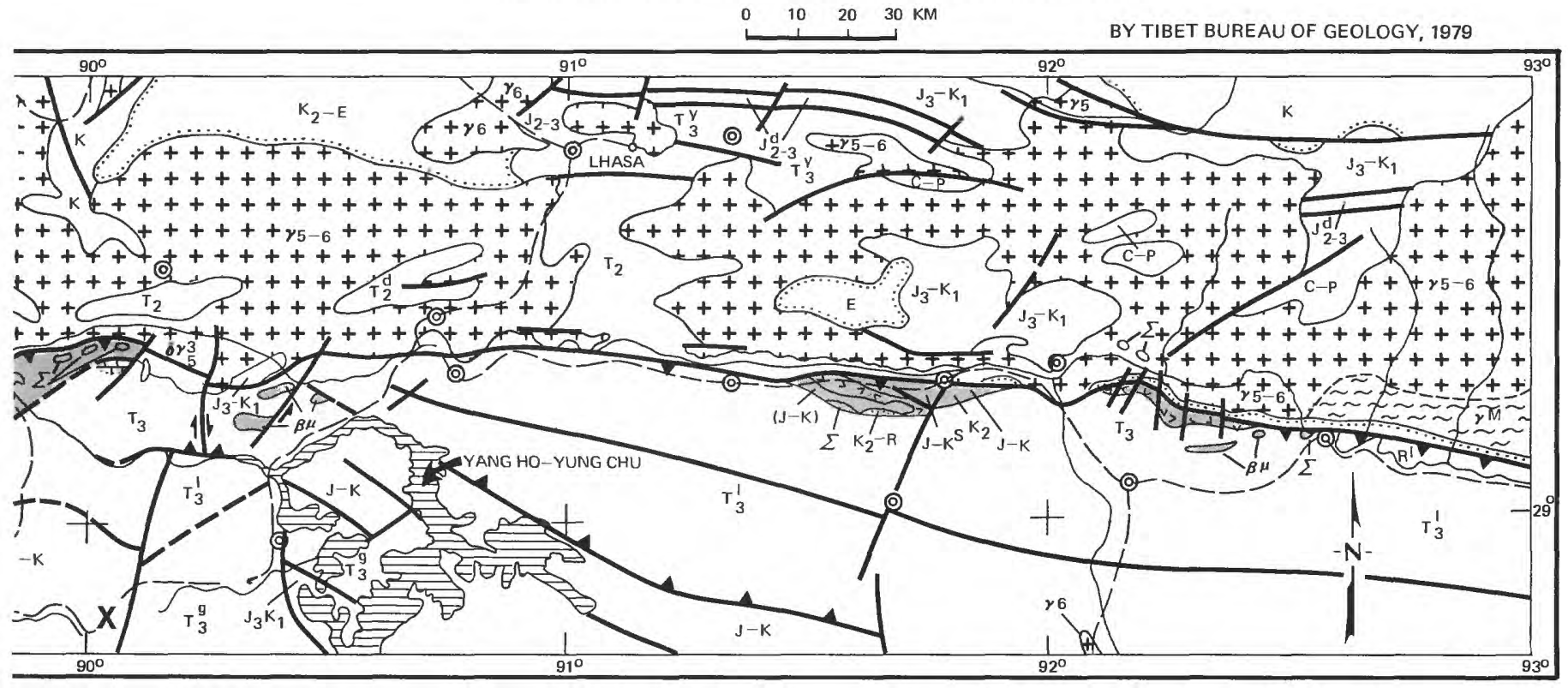

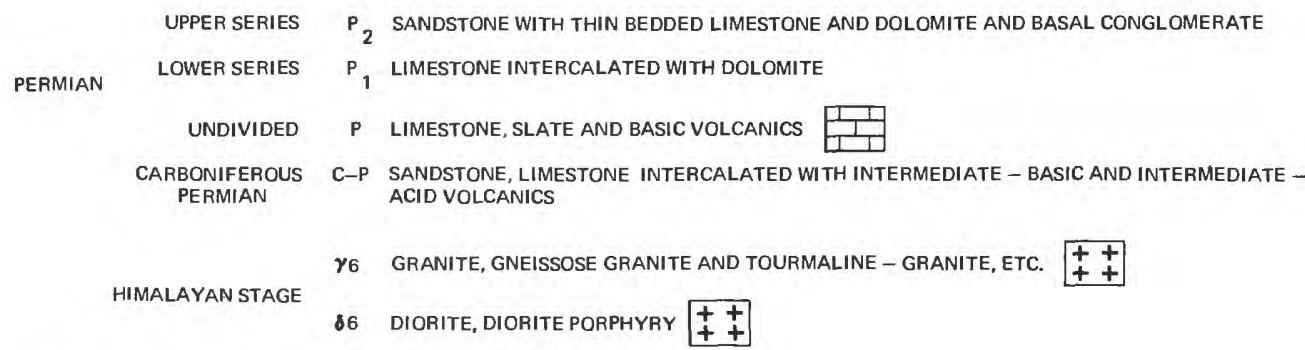

YENSHANIAN - HIMALAYAN $\boldsymbol{\gamma}_{5-6}$ GRANITE $+\underset{+}{+}+$

LATE YENSHANIAN STAGE

$\gamma_{5}^{3}$ GRANITE, GNEISSOSE GRANITE $\begin{aligned} & +t \\ & t+\end{aligned}$

$\delta \gamma_{5}^{3}$ GRANO - DIORITE, QUARTZITIC DIORITE AND DIORITE ETC. ++

$\gamma^{M}$ MIGMATIZED GRANITE $\underset{\sim}{\sim \sim}$

$\beta^{\mu}$ DIABASE AND GABBRO DIABASE DIKES

$\checkmark$ OPHIOLITE SUITE: GABBRO., GABBRO-DIABASE AND BASIC VOLCANICS $\begin{aligned} & x \times \times \\ & \times \times \times\end{aligned}$

$\Sigma$ OPHIOLITE: ULTRABASIC ROCKS $\begin{aligned} & 2^{2} 2 \\ & r^{2}+\end{aligned}$

- MAPPED AND INFERRED GEOLOGICAL BOUNDARY

MAPPED AND INFERRED UNCONFORMABLE BOUNDARY

$\checkmark$ MAPPED AND INFERRED REVERSE FAULT

MaPped and inferred normal fault

Strike Slip Fault

MAPPED AND INFERRED FAULT OF UNCERTAIN NATURE

- emplacement line of MÉ LANGe in ophiolite zone

$\therefore$ B... BOUNDARY OF ALLOCHTHONOUS BLOCKS IN MÉ LANGE

- ROADS O VILLAGE

X mélange outcrop discussed in text

Figure $9 \mathrm{~b}$. 


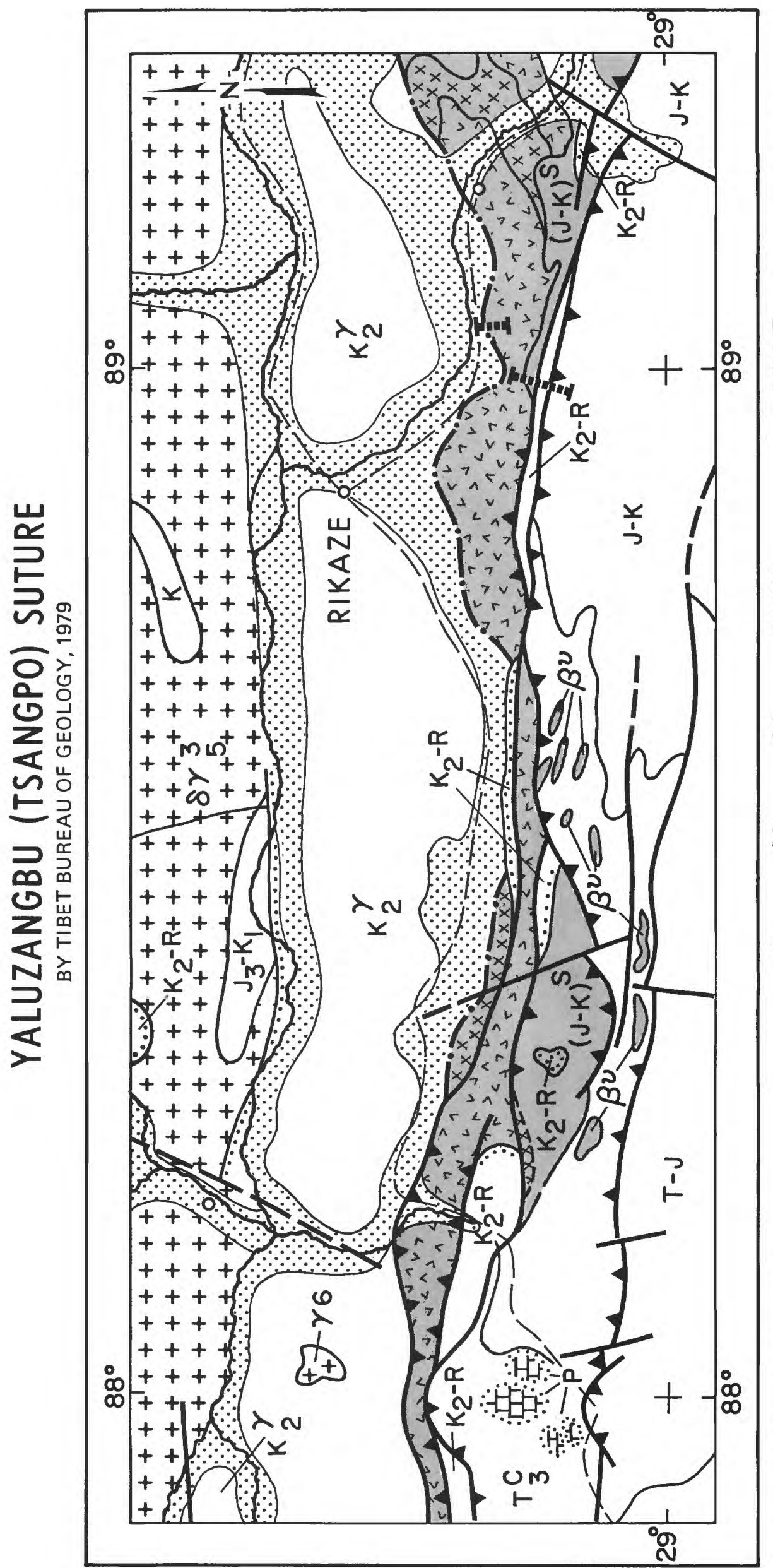

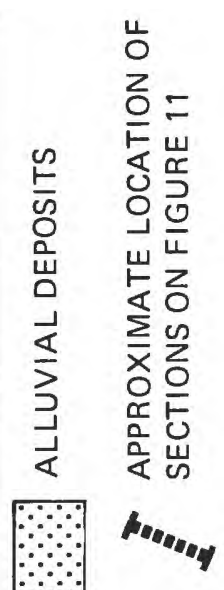

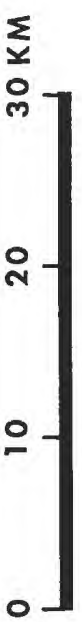

음
임
문 


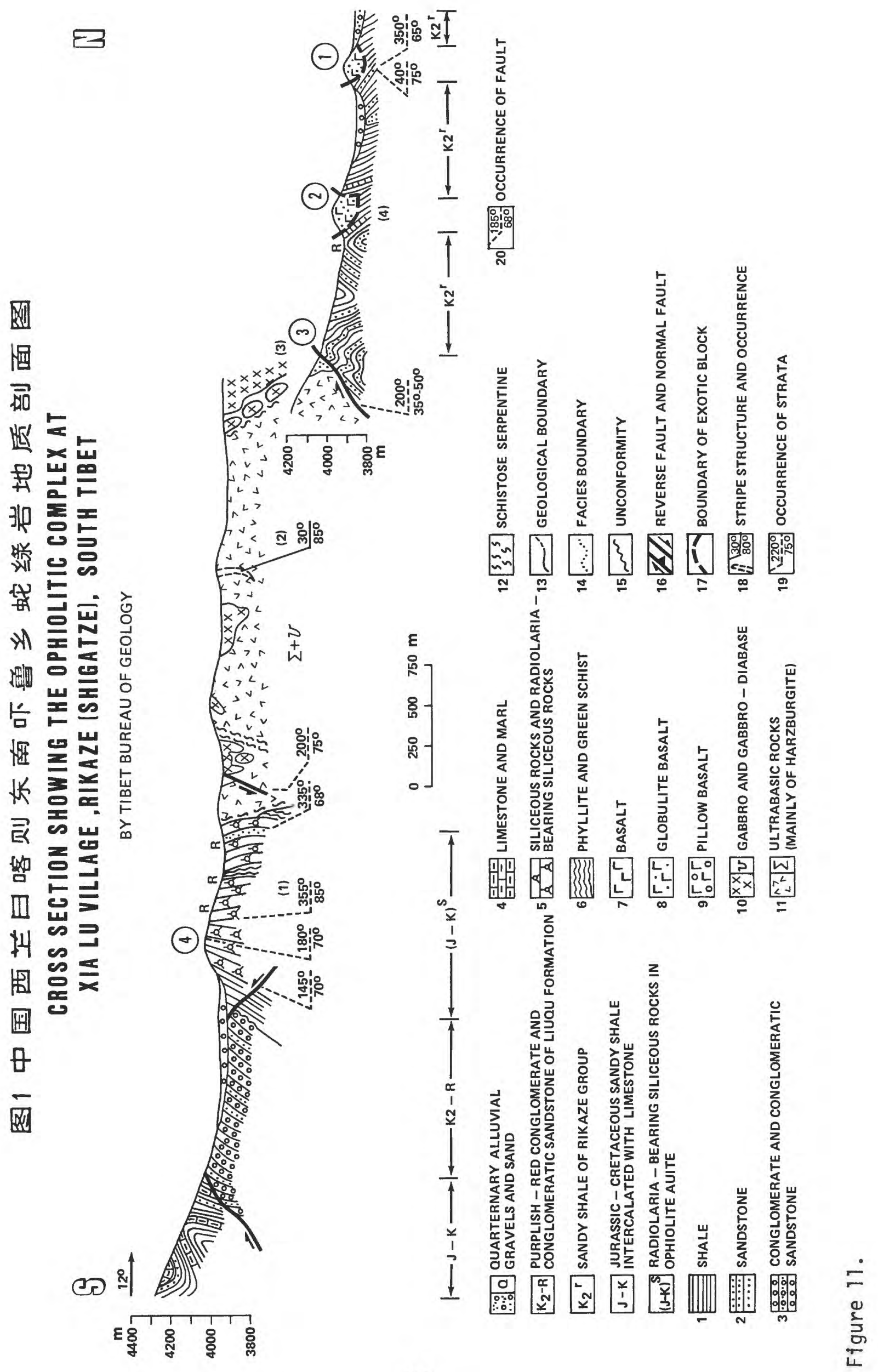


TRANSHIMALAYA - STRATIGRAPHY

AFTER SKETCH BY C. HOPSON

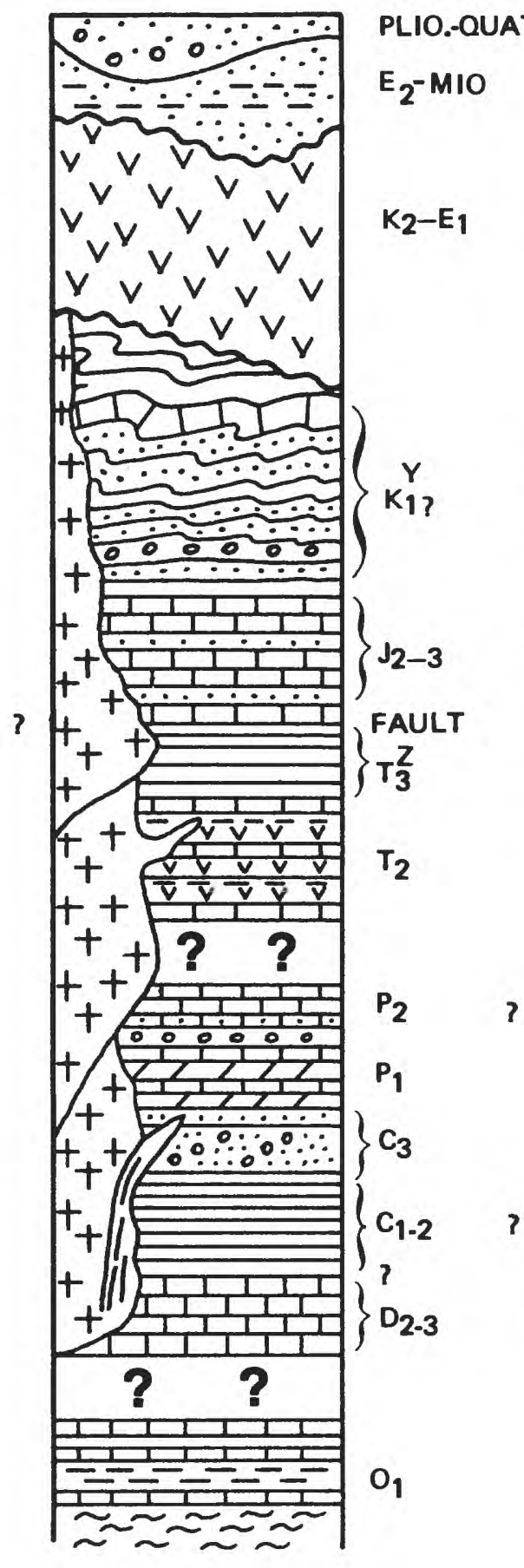
$\left\{\begin{array}{l}\text { ALTERNATIONS SANDSTONE, SHALE, MINOR LIMESTONES + } \\ \text { TUFFACEOUS SEDS. BASAL CONGLOMERATES \& }\end{array}\right.$ CONGLOMERATIC SANDSTONE; CONTAINING COAL SEAMS IN THE LOWER PART.

$\{$ XTLN. LIMESTONES INTERCALATED WITH QUARTZITIC

$\{$ SANDSTONE; SLATE NEAR THE TOP

$\{$ SANDY SLATE, WITH INTERCALATED LIMESTONES OR $\{$ VOLCANICS

$\{$ SANDSTONE LIMESTONES, SLATE, AND INTERM - BASIC AND INTERM - ACIDIC VOLCANICS

$?\left\{\begin{array}{l}\text { SANDSTONE WITH THIN BEDDED LIMESTONE AND } \\ \text { DOLOMITE AND BASAL CONGLOMERATES }\end{array}\right.$ LIMESTONE INTERCALATED WITH DOLOMITE

$\{$ QUARTIZITIC SANDSTONE,PEBBLE BEARING SLATE AND SANDSTONE

LIMESTONE ?

\{ PORPHYRITIC MICA GNEISS, BIOTITE GRANITIC GNEISS, STAUROLITE GARNET GNEISS MARBLE

Figure 12. 


\section{AILAO SHAN MOUNTAINS}

GEOLOGIC SKETCH MAP BY YUNNAN BUREAU OF GEOLOGY

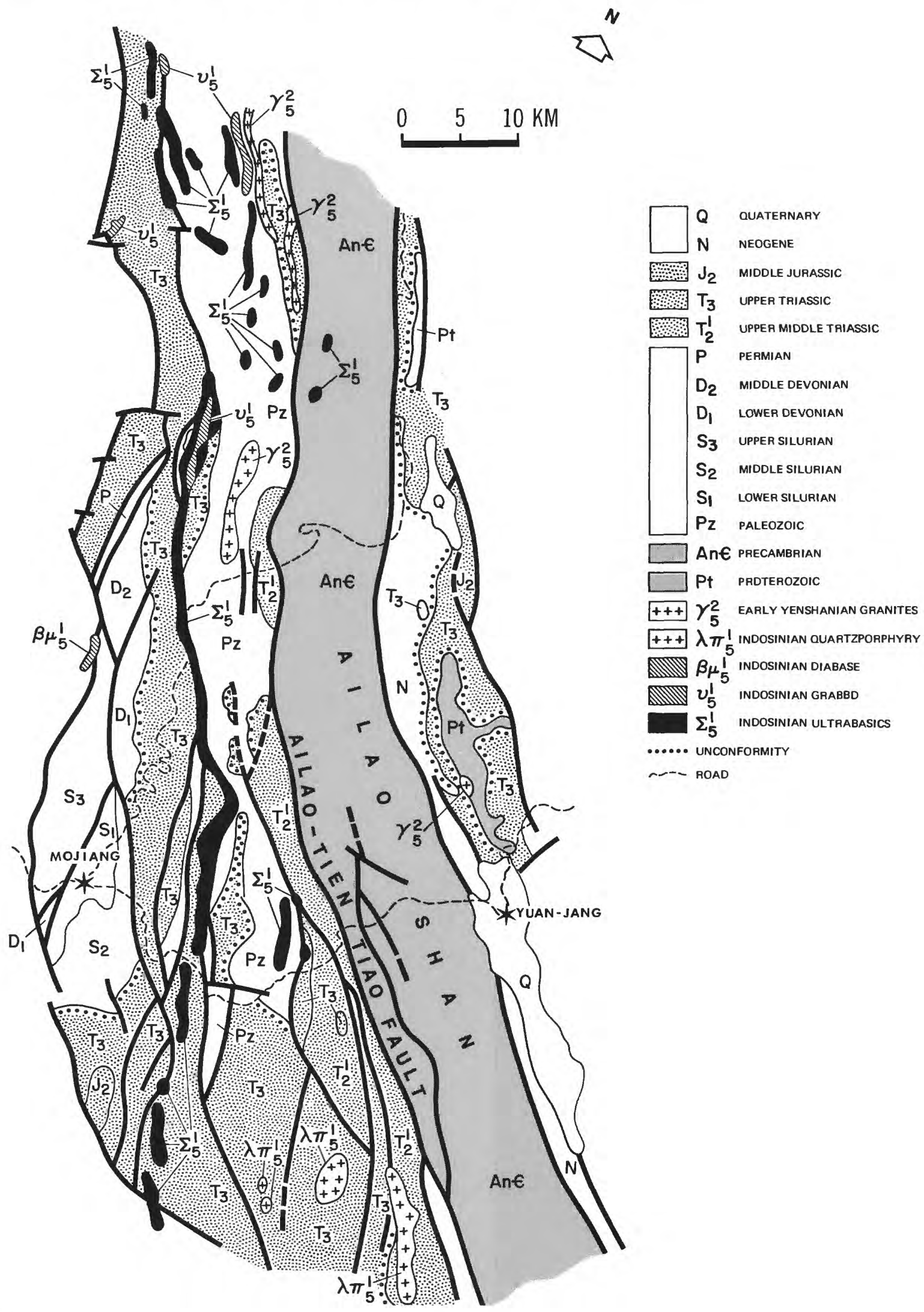

Figure 13. 


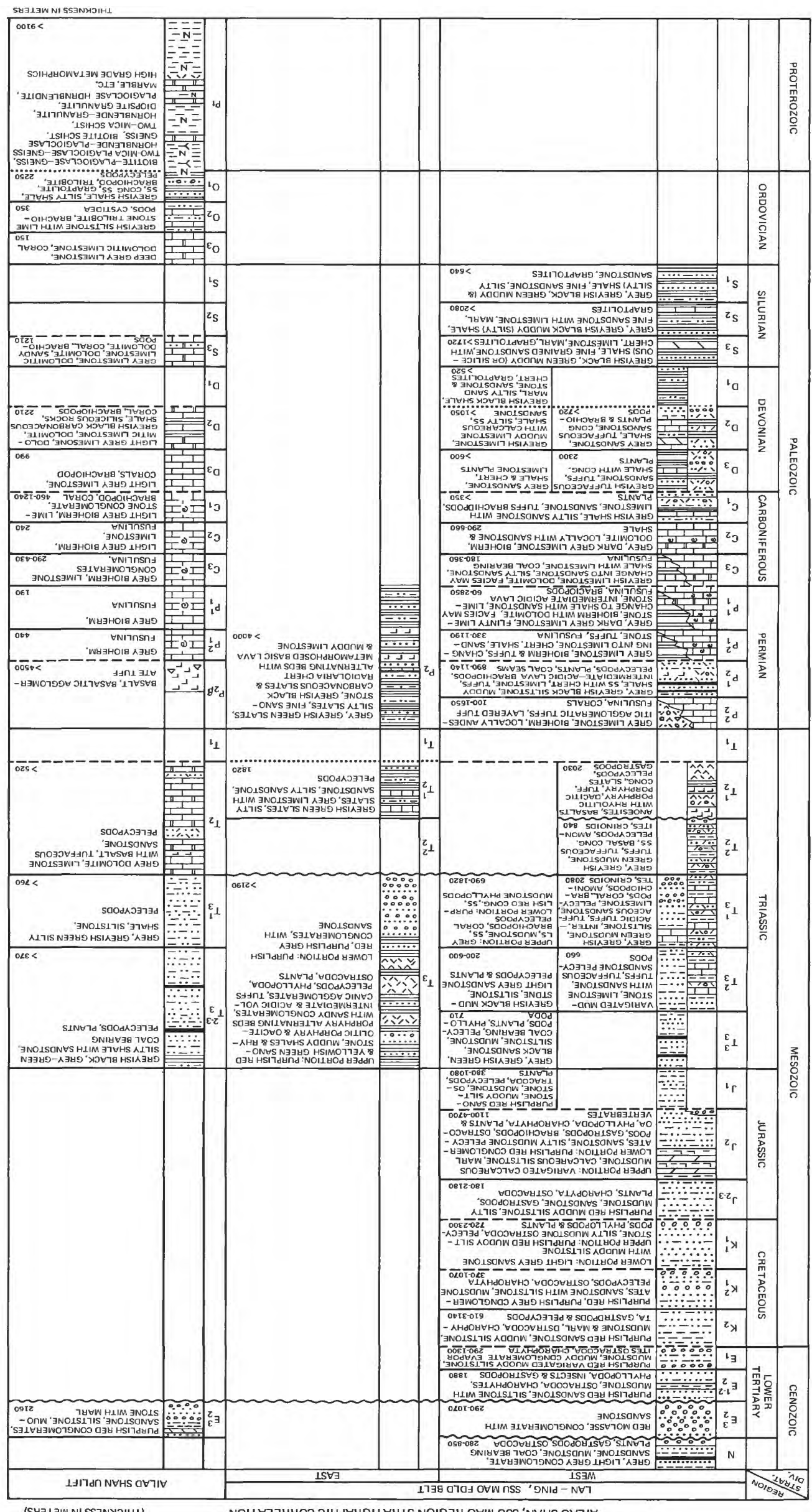



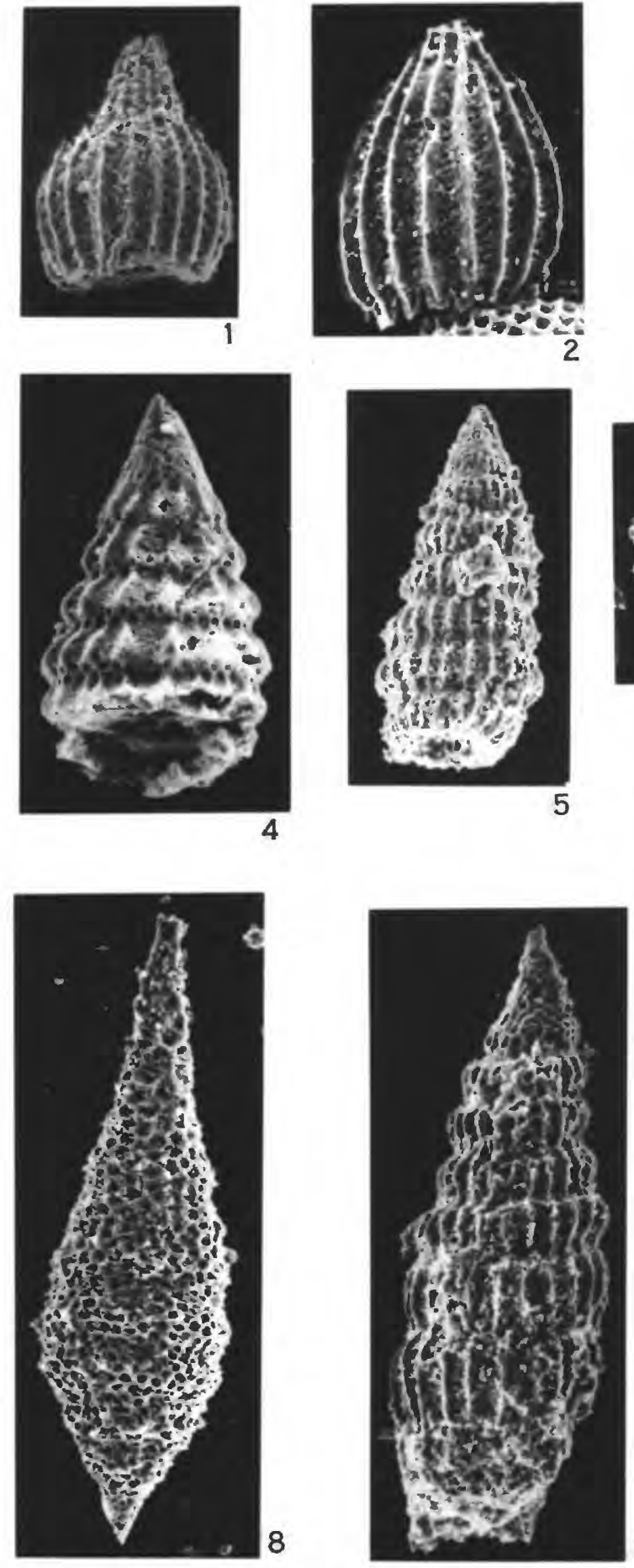
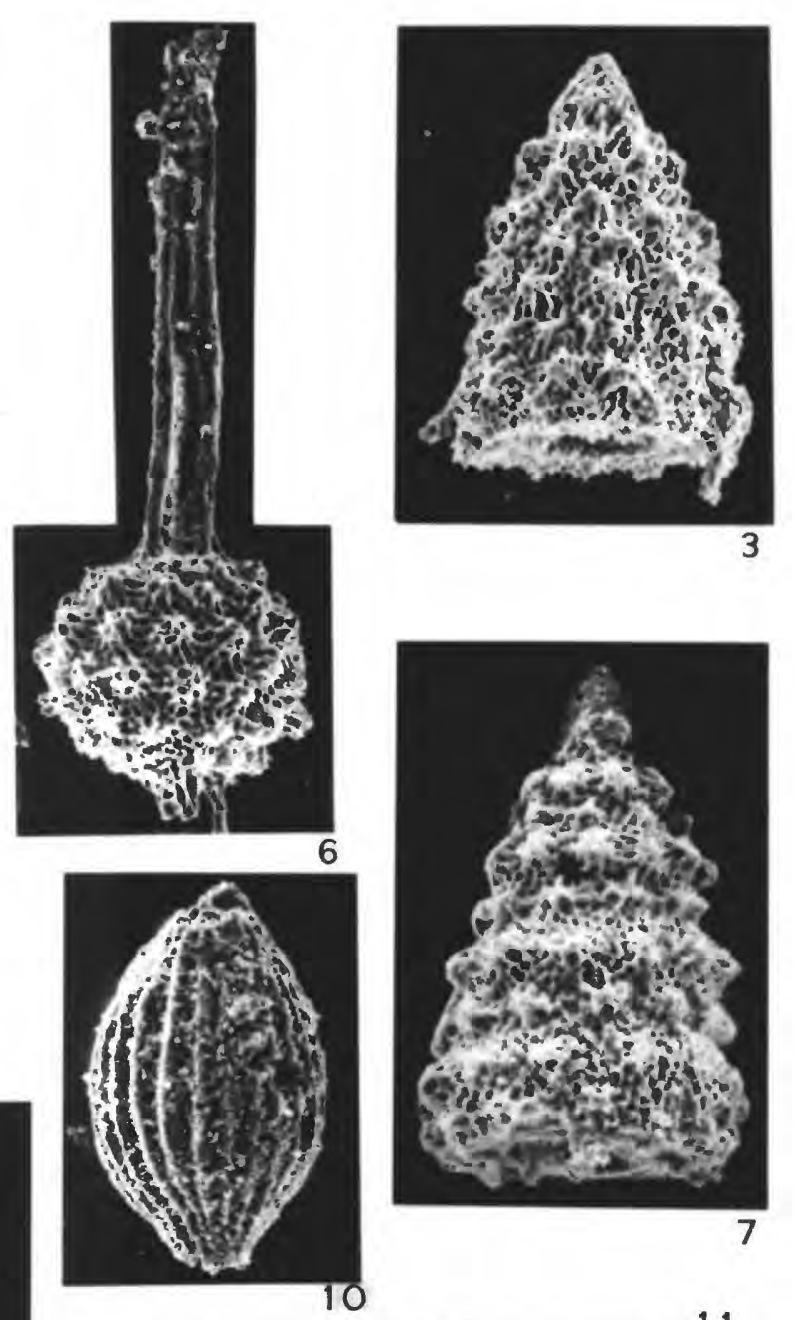

11

Figure 15. 


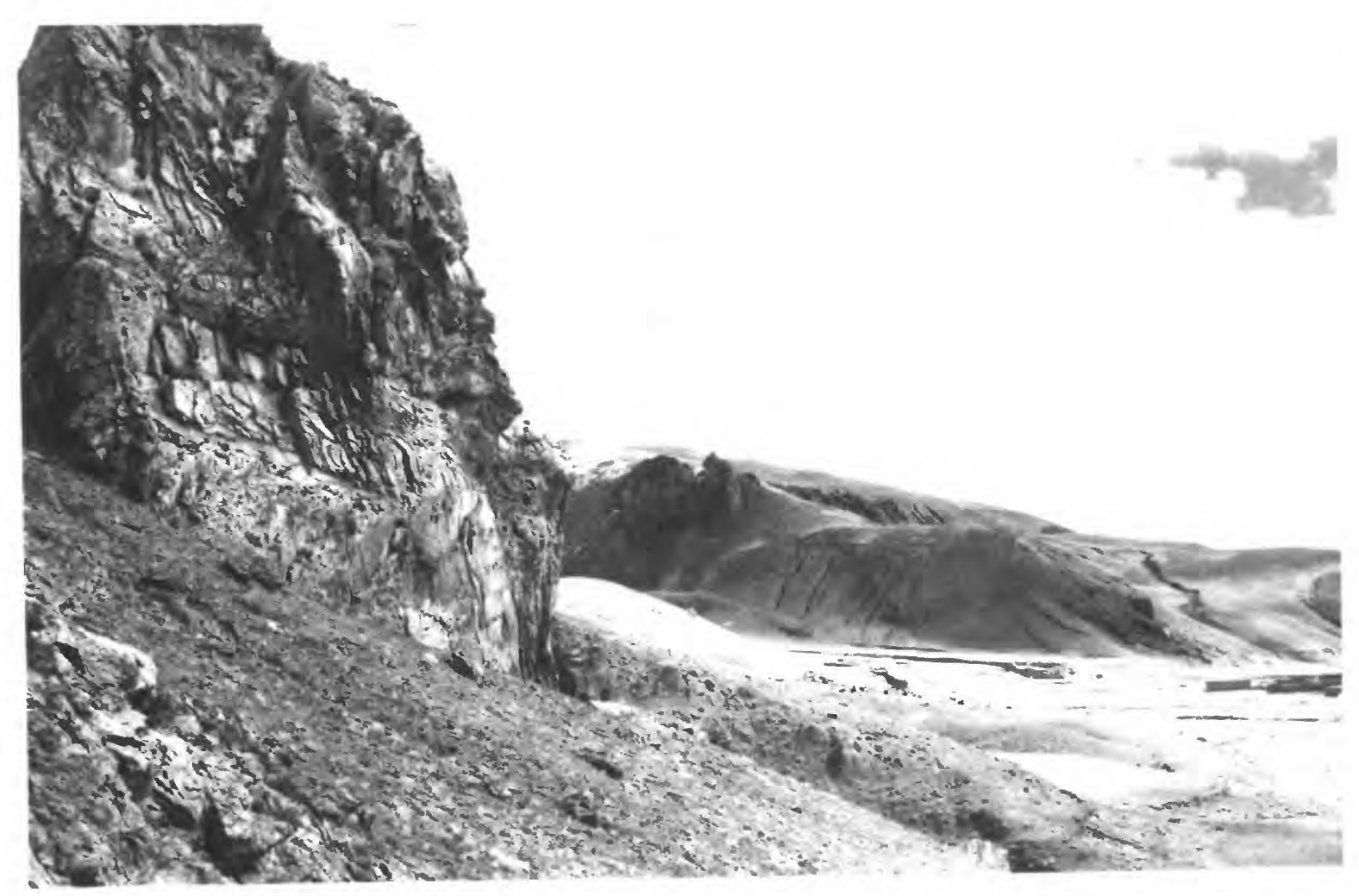

Figure 16.

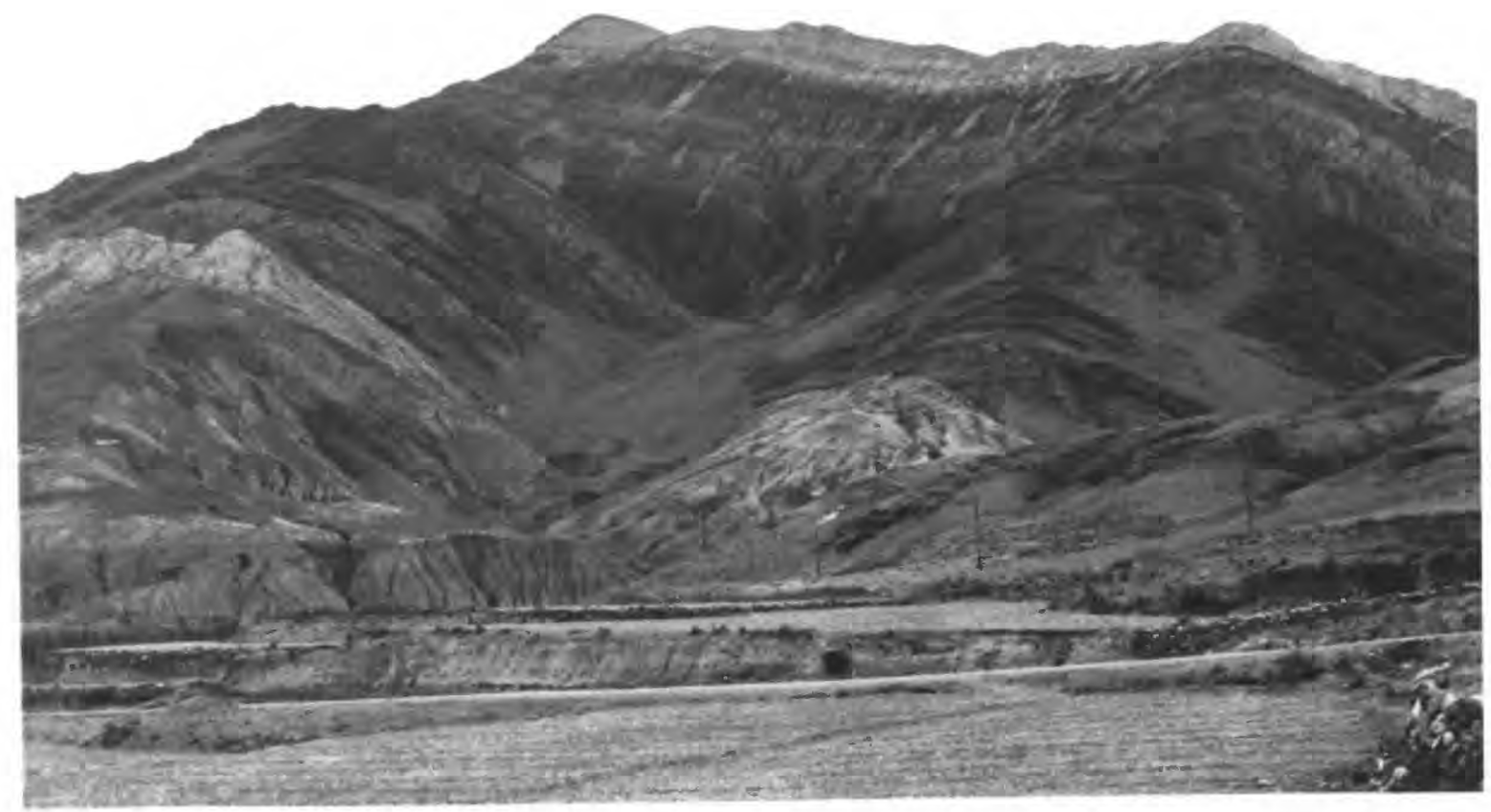

Figure 17. 


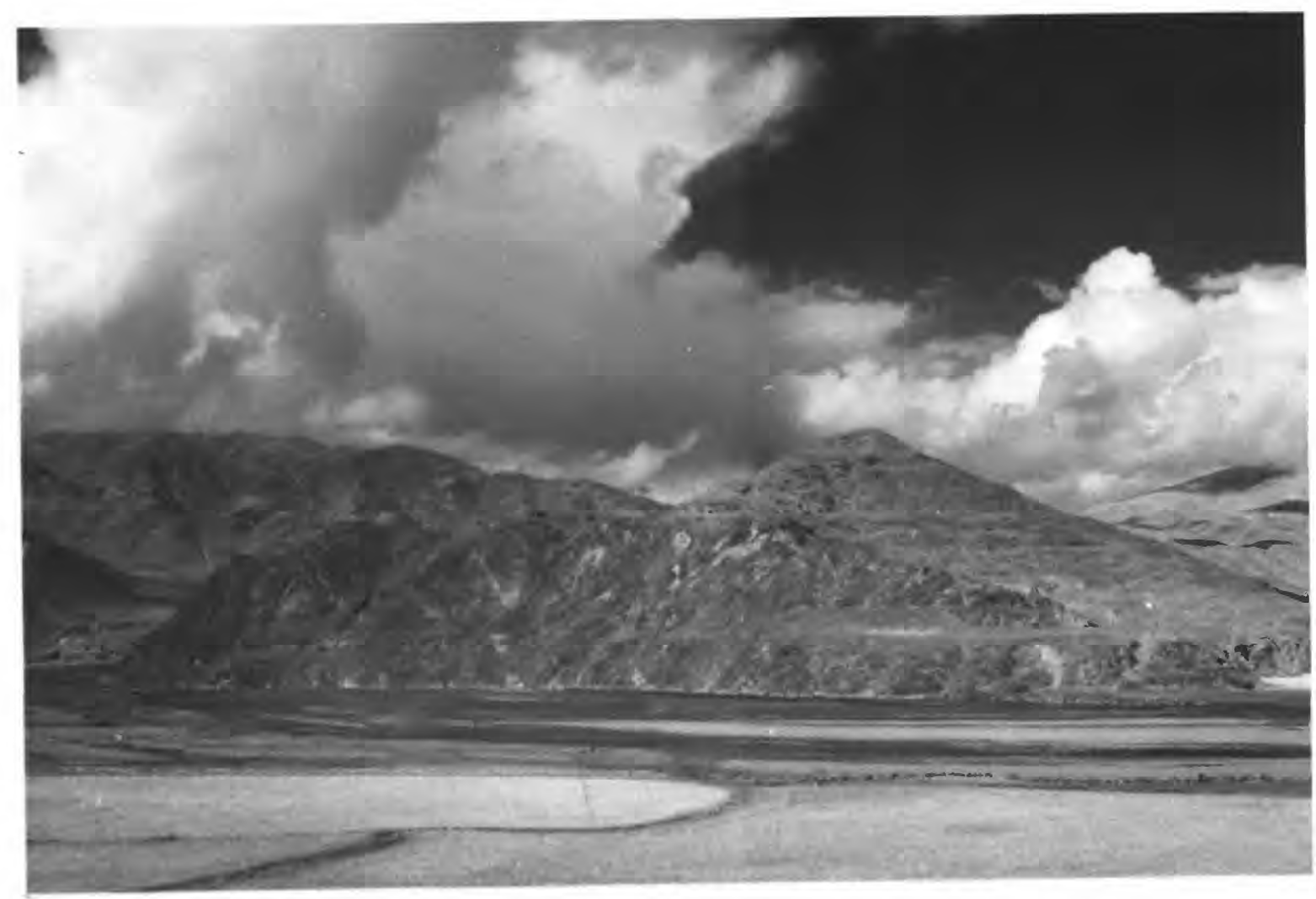

Figure 18.

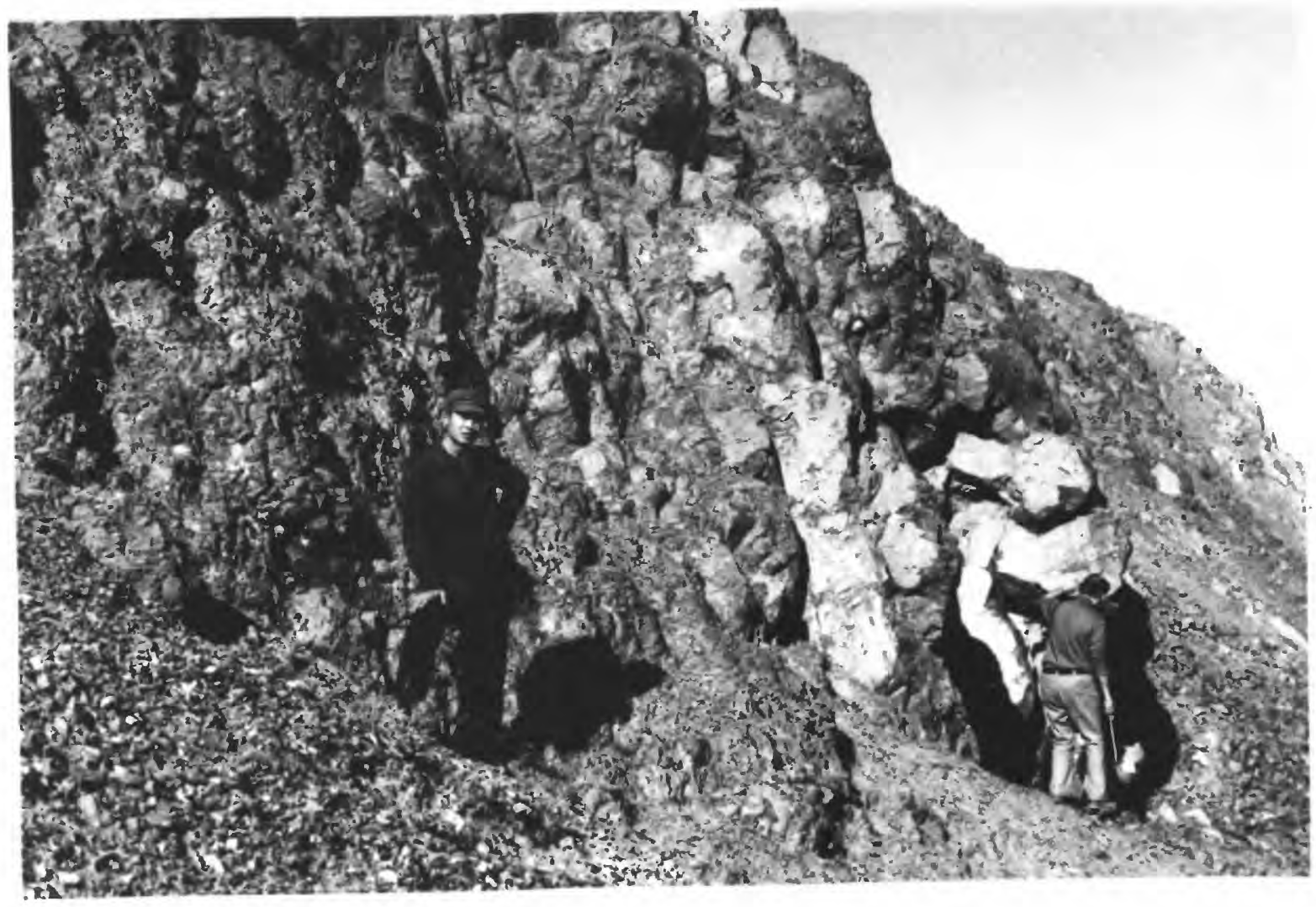

Figure 19. 


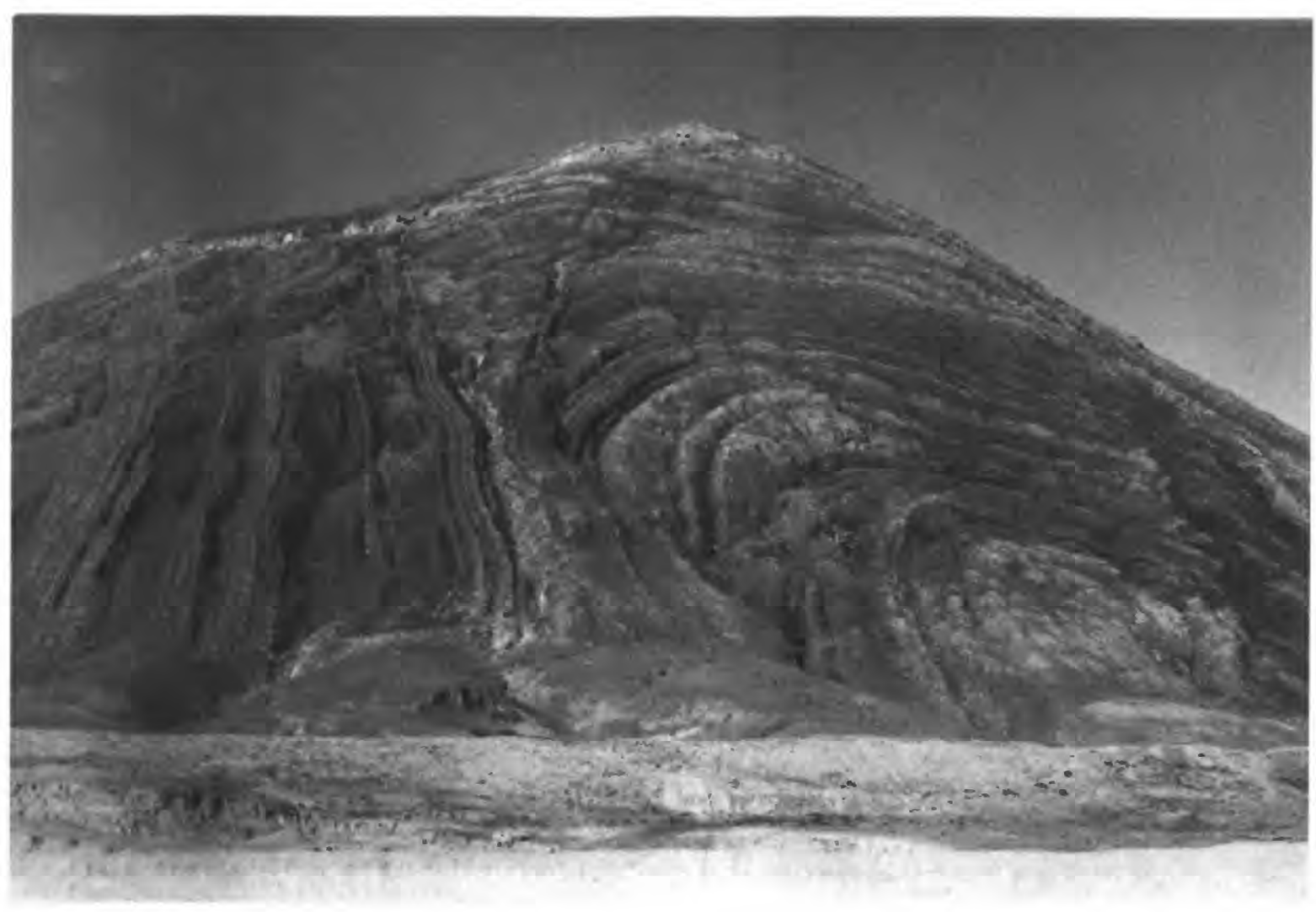

Figure 20.

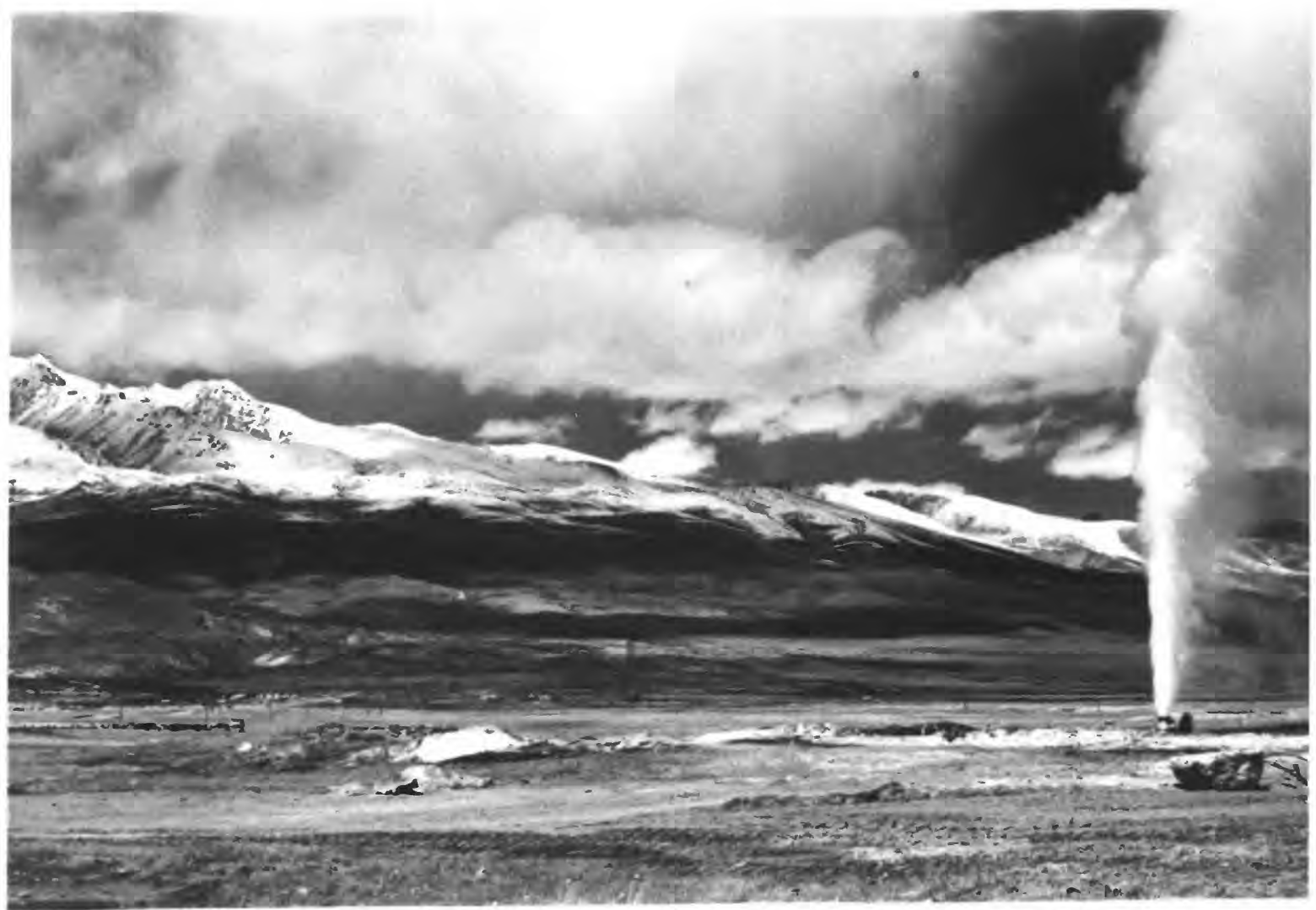

Figure 21. 


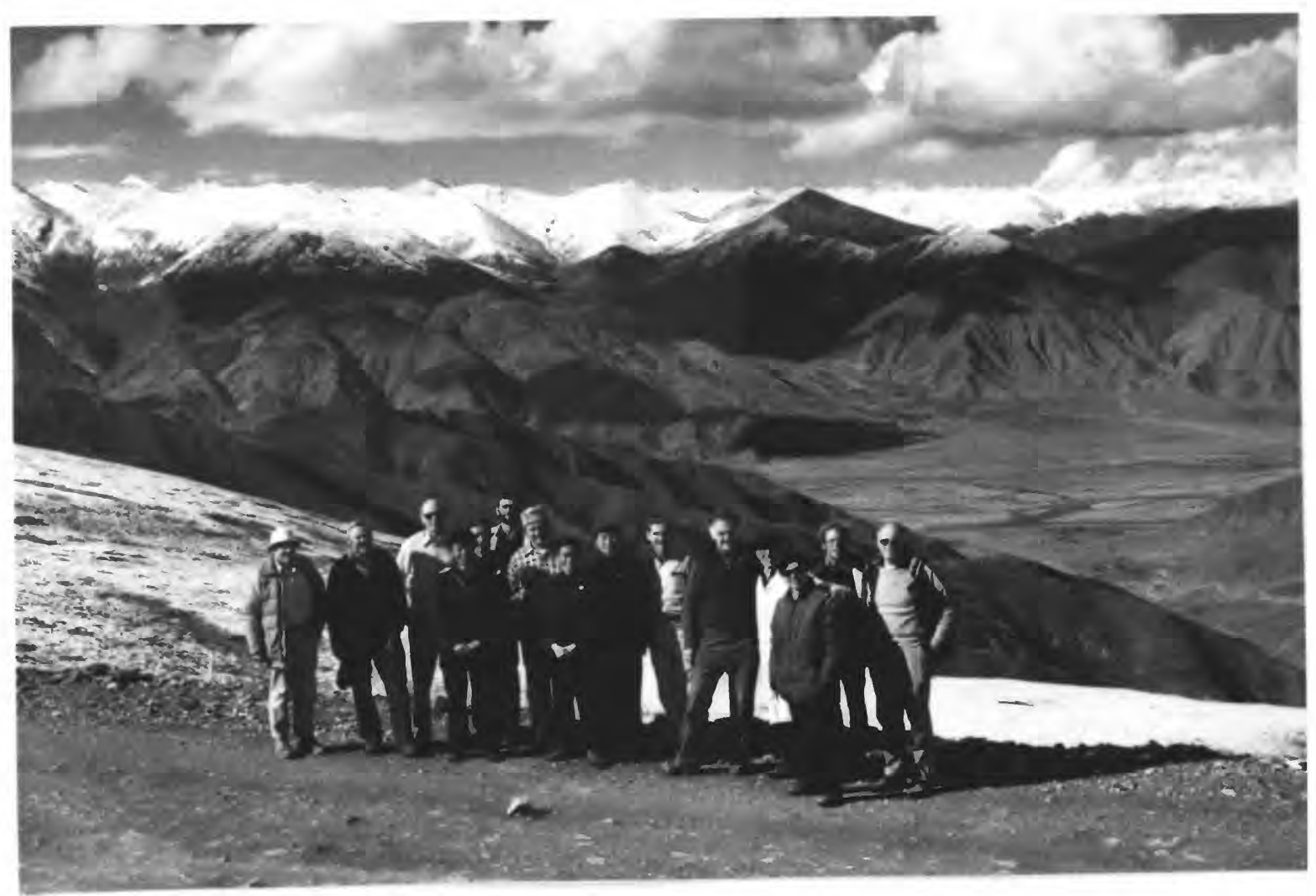

Figure 22.

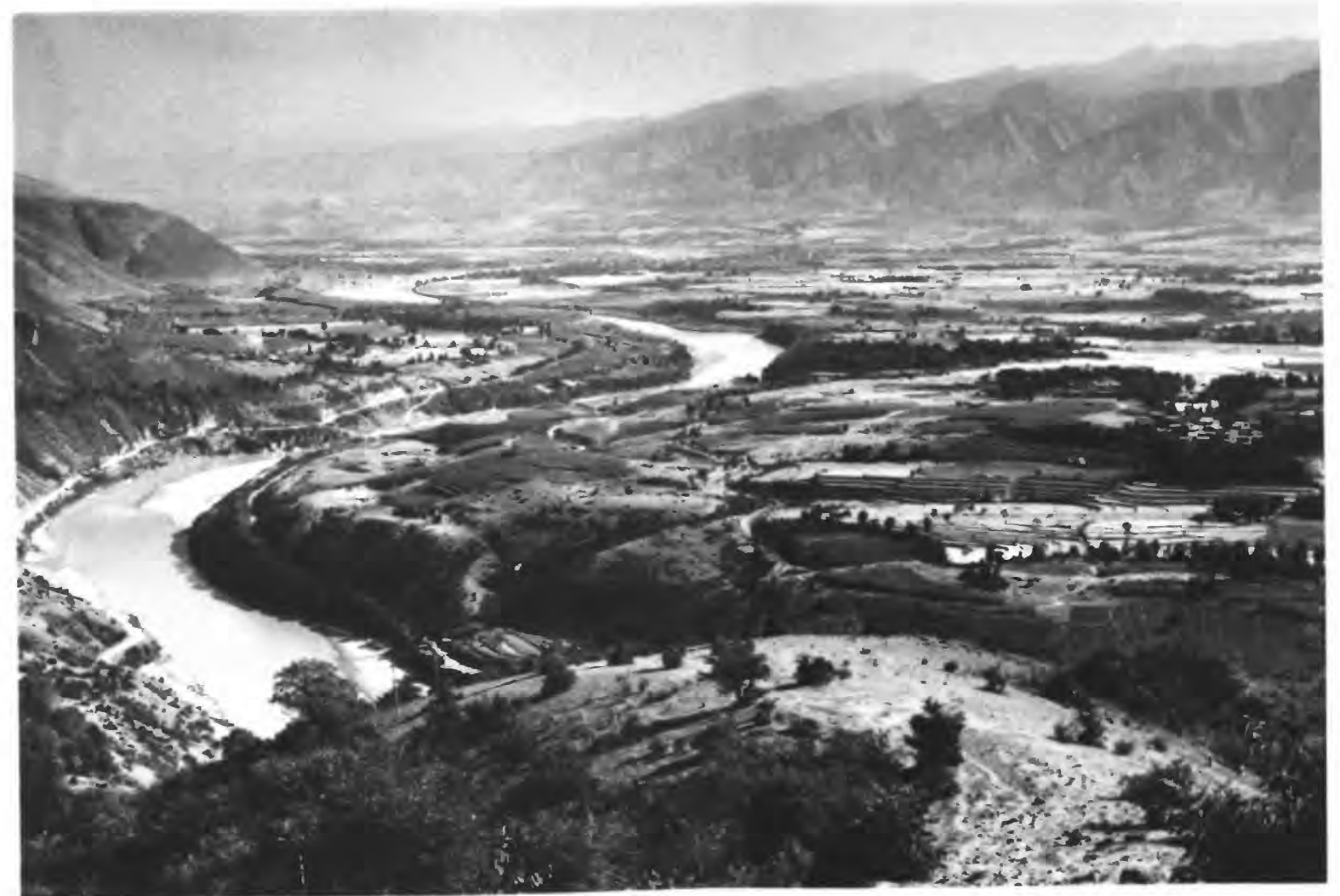

Figure 23. 
TABLE 1

CLASSIFICATION OF DEEP FRACTURES ACCORDING TO DEPTH

(AFTER HUANG CHI-CHING, 1978)

\begin{tabular}{|l|l|l|l|}
\hline \multirow{2}{*}{ NAME } & DEPTH & \multicolumn{2}{|c|}{ EXAMPLES } \\
\cline { 2 - 4 } CRUSTAL FRACTURE & & THE WORLD & CHINA \\
\hline -SIMLIC FRACTURE & $\begin{array}{l}\text { DISSECTING THE SIAL BUT NOT } \\
\text { CLEARLY EXTENDING INTO SIMA }\end{array}$ & MANY & $\begin{array}{l}\text { HEYUAN DEEP } \\
\text { FRACTURE }\end{array}$ \\
\cline { 2 - 4 } & $\begin{array}{l}\text { DISSECTING THE WHOLE CRUST } \\
\text { BUT NOT CLEARLY EXTENDING } \\
\text { INTO THE UPPER MANTLE }\end{array}$ & MANY & $\begin{array}{l}\text { EAST TSANGCHOW } \\
\text { DEEP FRACTURE }\end{array}$ \\
\hline $\begin{array}{l}\text { FRACTURE *) } \\
\text { TRANSLITHOSPHERIC } \\
\text { FRACTURE }\end{array}$ & $\begin{array}{l}\text { DISSECTING THE LITHOSPHERE } \\
\text { INTO THE ASTHENOSPHERE } \\
\text { AND EXTENDING } \\
\text { THE ASTHENOSPHERE }\end{array}$ & $\begin{array}{l}\text { RIFT VALLEYS } \\
\text { OF EAST AFRICA }\end{array}$ & $\begin{array}{l}\text { TANCHENG-LUKIANG } \\
\text { DEEP FRACTURE }\end{array}$ \\
\hline
\end{tabular}

*) LITHOSPHERIC FRACTURE AND TRANSLITHOSPHERIC FRACTURE MAY BE CALLED TRANSCRUSTAL FRACTURES. 
TABLE 2

PLATFORM CHARACTERISTICS

(ABSTRACTED FROM T. K. HUANG, 1960)

PARAPLATFORMS

RELATIVELY GREAT MOBILITY

SUBSTRATUM LESS CONSOLIDATED

BETWEEN 3000-6000 M OF SHALLOWWATER CARBONATES, FOLLOWED BY

CONTINENTAL SEDIMENTS

FORMATION OF MAJOR DEPRESSIONS AND UPLIFTS. THICK CONTINENTAL SEDIMENTARY FILL OF DEPRESSIONS

AXIAL AND MARGINAL SEDIMENTARY TROUGHS AND LINEAR AXIAL DEPRESSIONS

POLYCYCLICAL OROGENIC DEVELOPMENT, WITH FOLDING AND FAULTING

YENSHANIAN DEFORMATION IN FORM OF FOLDING AND FAULTING IN EASTERN CHINA

NUMEROUS DEEP FRACTURES IN AN AXIAL AND A MARGINAL POSITION

YOUNG GEOMORPHOLOGIC EVOLUTION AND RECENT TECTONICS
PLATFORMS (ORTHOPLATFORMS)

LESS MOBILITY

SUBSTRATUM (BASEMENT) MORE CONSOLIDATED

LESS THAN $3000 \mathrm{M}$ OF SEDIMENTS. THICK CONTINENTAL SEDIMENTS ABSENT

ONLY GENTLE ANTICLISES AND SYNECLISES. CLASTIC FILL IN SYNECLISES VIRTUALLY ABSENT

ABSENT OF MARGINAL TROUGHS AND AXIAL DEPRESSIONS

OROGENIC ACTIVITIES ABSENT. NO GRANITIC INTRUSIVES, BUT SOME BASALTIC VOLCANISM

NO POLYCYCLICAL FOLDING, DURING YENSHANIAN OROGENY

DEEP FRACTURES VIRTUALLY ABSENT

YOUNG GEOMORPHOLOGIC EVOLUTION AND RECENT TECTONICS SUBORDINATE 
TABLE 3

LIST OF THE PRINCIPAL DEEP FRACTURES IN CHINA

(AFTER HUANG CHI-CHING, 1978)

\begin{tabular}{|c|c|c|c|c|c|}
\hline $\begin{array}{l}\text { NUMBER } \\
* 1\end{array}$ & NAME OF DEEP FRACTURE ZONE & DEPTH & CHARACTER & $\begin{array}{l}\text { AGE OF } \\
\text { ACTIVITY }\end{array}$ & $\begin{array}{l}\text { MAGMATISM \& } \\
\text { METAMORPHISM }\end{array}$ \\
\hline 1 & DARBUT & L & s & PZ & os \\
\hline 2 & IRTISH & $\mathbf{L}$ & c-s & $\mathbf{P Z}$ & $\Sigma$ \\
\hline 3 & KARAMEILI & L & C-S & PZ & $\Sigma$ \\
\hline 4 & NORTH MARGIN OF CENTRAL TIENSHAN & L & c-S & PT ?, PZ & $\Sigma$ \\
\hline 5 & DERBUGAN & L & c-S & PZ & \\
\hline 6 & SILAMULUN & L & c-s & PZ & $\Sigma, \mathrm{GS}$ \\
\hline 7 & CHERCHEN & L & $s / s$ & PZ & \\
\hline 8 & $\begin{array}{l}\text { NORTHERN MARGIN OF INNER } \\
\text { MONGOLIAN AXIS }\end{array}$ & L & c-s & PT ?, PZ & $\Sigma$ \\
\hline 9 & ALTYN & L & $s / s$ & PZ & $\Sigma$ \\
\hline 10 & $\begin{array}{l}\text { NORTH NANSHAN-NORTHERN MARGIN OF } \\
\text { NORTH TSINLING-NORTH HUAIYANG }\end{array}$ & L & c-s & PT,PZ & OS, GS \\
\hline 11 & $\begin{array}{l}\text { NORTHERN MARGIN OF TSAIDAM- } \\
\text { SOUTHERN MARGIN OF NORTH TSINLING- } \\
\text { NORTH HUAIYANG }\end{array}$ & L & c-s & PZ & $\Sigma, M$ \\
\hline 12 & EAST KUNLUN & L & c-s & PZ & $\Sigma, M$ \\
\hline 13 & KANTZE-LITANG & L & $\mathrm{C}-\mathrm{S}$ & PZ & $\Sigma$ \\
\hline 14 & CHINSHAKIANG-RED RIVER & $\mathbf{L}$ & $c-s$ & PZ & $\Sigma, M$ \\
\hline 15 & LANTSANGKIANG & L & $\mathrm{C}-\mathrm{S}$ & PZ & $\Sigma$ \\
\hline 16 & NUKIANG & L & c-s & PZ & $\Sigma$ \\
\hline 17 & ANNINGHO & L & c-S & PZ & $\Sigma$ \\
\hline 18 & HSIAOKIANG & c & c-s & PZ & $\boldsymbol{\beta}$ \\
\hline 19 & LUNGMENSHAN & L & c-s & PZ & $\Sigma$ \\
\hline 20 & LINGSHAN & c & c-s & PZ & $\gamma$ \\
\hline 21 & WUCHUAN-SZEHWEI & c & A & PZ & $\gamma$ \\
\hline 22 & HEYUAN & c & A & $M Z$ & $\gamma$ \\
\hline 23 & LISHUI-HAIFENG & c & $\mathrm{C}-\mathrm{S}$ & PZ & $\gamma$ \\
\hline 24 & CHANGLE-AMOY & c & C-S & $M Z$ & $\gamma$ \\
\hline 25 & TAIHANGSHAN & c & c-s & $M Z$ & $\gamma$ \\
\hline 26 & EAST TSANGCHOW & C & $\mathrm{T}-\mathrm{S}$ & $M Z$ & $\beta$ \\
\hline 27 & LIAOCHENG-LANKAO & c & $T-S$ & $\cdot M Z$ & $B$ \\
\hline 28 & TANCHENG-LUKIANG & L & $s / s$ & PT ?, MZ? & $\Sigma$ \\
\hline 29 & YILAN-YITUNG & c & $\mathbf{T}-\mathbf{S}$ & $M Z$ & $\boldsymbol{\beta}$ \\
\hline 30 & FUSHUN-MISHAN & L & $s / s$ & PZ & $\boldsymbol{B}$ \\
\hline 31 & TSANGPO-INDUS & $T$ & c-s & $M Z$ & OS, M \\
\hline 32 & LONGITUDINAL VALLEY OF TAIWAN & $T$ & $s / s$ & MZ & OS, M, GS \\
\hline
\end{tabular}

*) NUMBERING HERE CORRESPONDS TO NUMBERS IN FIGURE 2 SHOWING THUS 3,6 , ETC. EXPLANATION

$$
\begin{aligned}
\mathrm{T}= & \text { TRANSLITHOSPHERIC FRACTURE ZONE } \\
\mathrm{L}= & \text { LITHOSPHERIC FRACTURE ZONE } \\
\mathrm{C}= & \text { CRUSTAL FRACTURE ZONE } \\
\mathrm{C}-\mathrm{S}= & \text { COMPRESSION AND COMPRESSION-SHEAR } \\
\mathrm{T}-\mathrm{S}= & \text { TENSION AND TENSION-SHEAR } \\
\mathrm{S}= & \text { SHEAR (S/S SINISTRAL; S/D DEXTRAL) } \\
\mathrm{A}= & \text { COMPRESSION-SHEAR AND TENSION-SHEAR } \\
& \text { ALTERNATING }
\end{aligned}
$$

PT = POLYCYCLICALLY ACTIVE SINCE PROTEROZOIC $P Z=$ POLYCYCLICALLY ACTIVE SINCE PALAEOZOIC $M Z=$ POLYCYCLICALLY ACTIVE SINCE MESOZOIC OS = OPHIOLITIC SUITES $\Sigma=$ BASIC AND ULTRABASIC COMPLEXES $\gamma=$ GRANITOID PLUTONS

$\boldsymbol{\beta}=$ BASALTS

$M=$ MÉLANGES

$\mathrm{GS}=$ GLAUCOPHANE SCHISTS 


\section{TABLE 4}

EAST CENTRAL TIBETAN PLATEAU SUB - REGION III 1

BY TIBET BUREAU OF GEOLOGY, 1979

WEST EAST

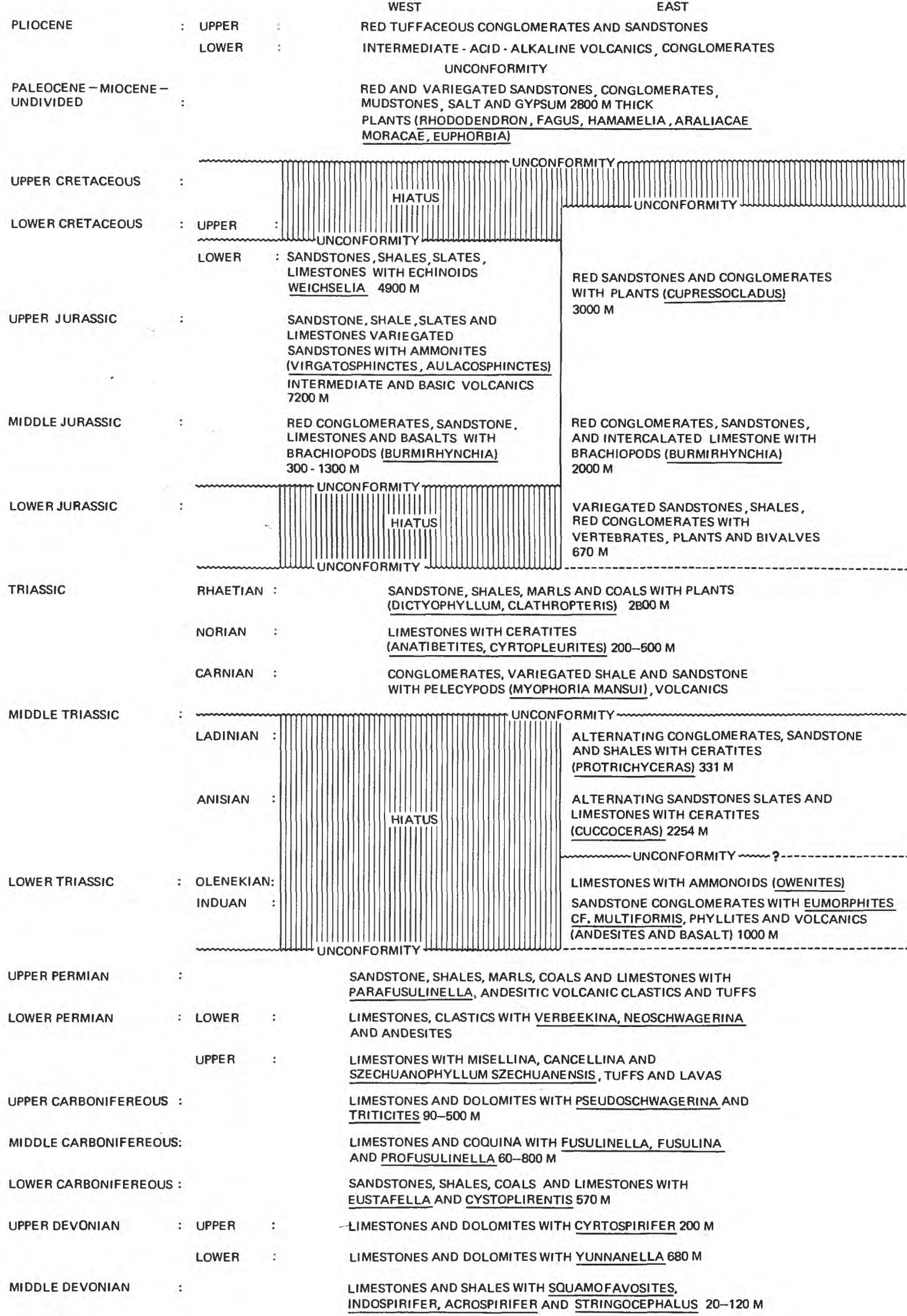

SILURIAN-

LOWER DEVONIAN

MAY BE PRESENT BUT NOT YET DOCUMENTED

ORDOVICIAN

SHALE WITH DIDYMOGRAPTUS HIRUNDO AND ORTHIS SHENSINENSIS 
CENTRAL TIBETAN PLATEAU SUB - REGION III 2

BY TIBET BUREAU OF GEOLOGY, 1979

PLIOCENE

PALEOCENE-MIOCENE

UPPER CRETACEOUS

LOWER CRETACEOUS

UPPER JURASSIC

MIDDLE JURASSIC

LOWER JURASSIC

UPPER TRIASSIC

MIDDLE TRIASSIC

LOWER TRIASSIC

UPPER PERMIAN

LOWER PERMIAN

UPPER AND MIDDLE CARBONIFEROUS

LOWER CARBONIFEROUS :

UPPER DEVONIAN

MIDDLE AND LOWER : DEVONIAN

LOWER PALEOZOIC
ABSENT

: UPPER PART : ALTERNATING PURPLISH RED CONGLOMERATES, AND SANDSTONE MIDDLE PART: GREYISH RED GREYWACKE INTERBEDDED WITH YELLOW GREYWACKES

LOWER PART : GREYISH GREEN AND GREYISH PURPLE MUDSTONES

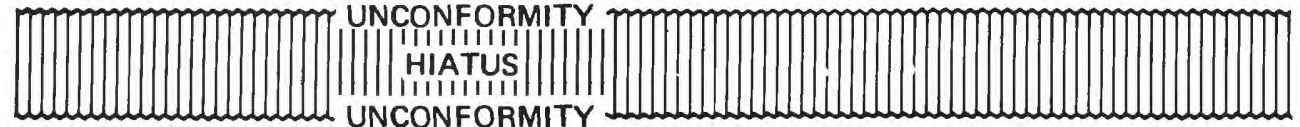

PURPLISH RED CONGLOMERATES, SANDSTONE AND MUDSTONES $350 \mathrm{M}$

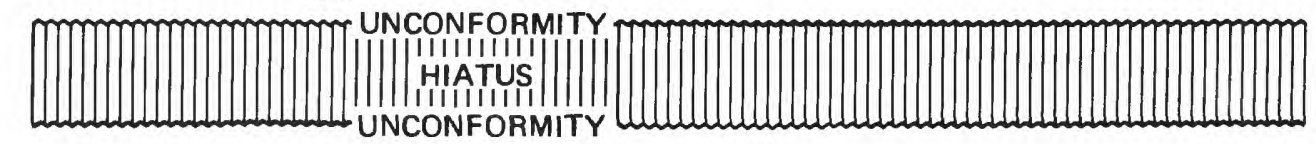

: UPPER PART : LIMESTONES, PURPLISH RED AND GREY SANDSTONE AND SHALES ALTERNATING WITH INTERBEDDED VOLCANICS AND TUFFS WITH DOLIKEPHALITES AND BURMIRHYNCHIA $4200 \mathrm{M}$

LOWER PART : LIMESTONES AND SHALES INTERCALATED WITH MUDDY SHALES WITH OPPELIA, WITCHELLIA AND DORSEFENSIA

NO INFORMATION INFERRED TO BE PRESENT

ALTERNATING SANDSTONE, SHALES AND MARLS, MOSTLY CONTINENTAL WITH SOME MARINE TONGUES. DICTOPHYLLUM, CLATHOPTERIS, MYOPHORIOPSIS $300 \mathrm{M}$

SANDSTONES INTERCALATED WITH LIMESTONES AND FINE CONGLOMERATES WITH ARTHABERITES ALDANDRAE, CYMNITES INCULTUS, CUCCOCERAS YOGA $100 \mathrm{M}$

: OLENEKIAN : LIMESTONES ALTERNATING WITH SHALES WITH MYOPHORIA COSTATA, EUMORPHOTIS INAEQUICOSTATA $450 \mathrm{M}$

INDUAN : FINE SANDSTONES INTERCALATED WITH MUDSTONES, COALS AND MARLS, CLARAIA STACHEI AND CLARAIA AURITA

LIMESTONE, SANDSTONE, SHALES AND COAL WITH PALEOFUSULINA NANA, P SINENSIS, SPHENOPHYLLUM

FAULT CONTACT

: UPPER PART : LIMESTONE INTERCALATED WITH SHALES

LOWER PART : LIMESTONE INTERCALATED WITH LIGHT RED LIMESTONE

SLATES, LIMESTONE, SANDSTONE AND SHALE WITH COALS WITH PSEUDOSCHWAGERINA, TRITICITES AND AMYGDOPHYLLUM

SANDSTONE AND SLATES INTERCALATED WITH THIN COAL BEDS WITH DIPHYLLUM, CHONETES, GIGANTOPRODUCTUS

GREYISH GREEN SHALE INTERCALATED WITH SANDSTONE, LIMESTONE AND CONGLOMERATES $1000 \mathrm{M}$

NOT REPORTED, BUT POSSIBLY PRESENT

SCHISTS, MARBLES OCCASIONALLY ASSOCIATED WITH GNEISS 


\section{TABLE 6}

\begin{tabular}{|c|c|}
\hline & WEST CENTRAL TIBETAN PLATEAU SUB - R \\
\hline & BY TIBET BUREAU OF GEOLOGY, 1979 \\
\hline POST CRETACEOUS & 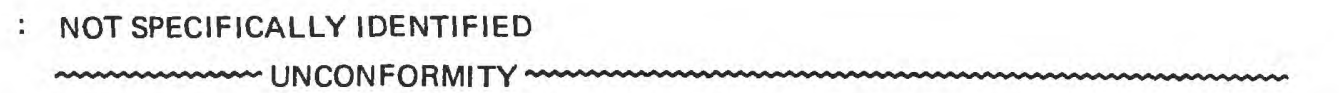 \\
\hline LOWER CRETACEOUS & $\begin{array}{ll}\text { : UPPER PART : } & \text { PURPLISH-RED SANDSTONE INTERCALATED WITH MARL } \\
\text { LOWER PART: } & \text { BIOCLASTIC LIMESTONE WITH PTERIA, ASTARTE ?, AND NERINEA }\end{array}$ \\
\hline $\begin{array}{l}\text { UPPER AND MIDDLE } \\
\text { JURASSIC }\end{array}$ & $\begin{array}{l}\text { : GREYISH BLACK LIMESTONE AND MUDSTONES WITH LIOSTREA, ASTRORHIZOPORA, } \\
\text { THECOSMILIA TIBETENSIS }\end{array}$ \\
\hline LOWER JURASSIC & PRESENCE SUSPECTED BUT NOT DOCUMENTED \\
\hline $\begin{array}{l}\text { TRIASSIC } \\
\text { UPPER PERMIAN }\end{array}$ & 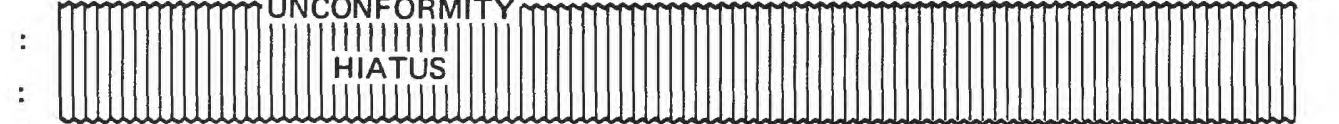 \\
\hline LOWER PERMIAN & $\begin{array}{l}\text { : SANDSTONE, SHALES AND LIMESTONE WITH SCHWAGERINA, } \\
\text { NEOSCHWAGERINA CHENI, MONODIEXODINA WANNERI }\end{array}$ \\
\hline UPPER CARBONIFEROUS & $\begin{array}{l}\text { : LIMESTONE AND SANDSTONE WITH BOULTONIA WILLIS, TRITICITES ALTUS, } \\
\text { PSEUDOFUSULINA OVATA }\end{array}$ \\
\hline MIDDLE CARBONIFEROUS & : $\overline{P R E S E N C E ~ S U S P E C T E D ~ B U T ~ N O T ~ D O C U M E N T E D ~}$ \\
\hline LOWER CARBONIFEROUS & $\begin{array}{l}\text { : PURPLISH RED CONGLOMERATES AND SANDSTONE WITH AVONIA, } \\
\text { NUCLEOSPIRA OBESA, CAMAROSPIRA FABULITES }\end{array}$ \\
\hline UPPER DEVONIAN & : LIMESTONE BARRANDOPHYLLUM, MESOPLICA, WHIDBORNELLA, OVATIA \\
\hline MIDDLE DEVONIAN & : QUARTIZITIC SANDSTONE INTERCALATED WITH SILICEOUS LIMESTONE AND MARBLE \\
\hline $\begin{array}{l}\text { LOWER DEVONIAN, } \\
\text { UPPER AND MIDDLE } \\
\text { SILURIAN }\end{array}$ & : PRESENCE SUSPECTED, BUT NOT DOCUMENTED \\
\hline LOWER SILURIAN & $\begin{array}{l}\text { : FLESH RED, LIGHT YELLOW OR GRAYISH WHITE, FELDSPATHIC QUARTZSANDSTONE } \\
\text { WITH HINDELLA XIZANGENSIS }\end{array}$ \\
\hline R PALEOZOICS & $\mathrm{N}$ \\
\hline
\end{tabular}


TABLE 7

NORTH TIBETAN PLATEAU KEKEXILI - REGION IV

BY TIBET BUREAU OF GEOLOGY, 1979

PLIOCENE : :

MIOCENE-UPPER

TRIASSIC (NORIAN) :

UPPER TRIASSIC : CARNIAN:

MIDDLE TRIASSIC-

UPPER PERMIAN :

LOWER PERMIAN :
BROWNISH RED SILTSTONE AND MUDSTONE WITH INTERCALATED SANDSTONE AND THIN GYPSUM BEDS

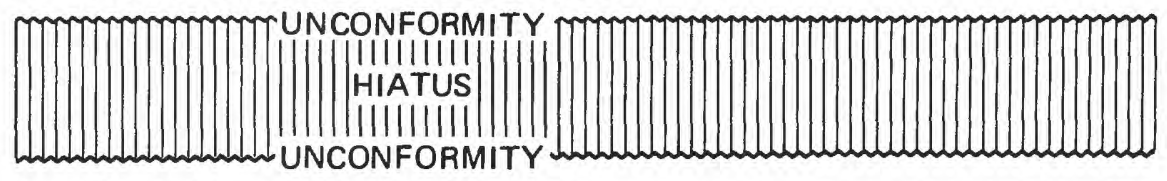

3000 M SANDSTONE AND SHALES (FLYSCH WITH DISTINCT RHYTHMITES) WITH INTERCALATED LIMESTONE, ALL SLIGHTLY METAMORPHOSED

INFERRED TO BE PRESENT BUT NOT DOCUMENTED

900-2000 M SLIGHTLY METAMORPHIC DARK GRE YISH GREEN ARKOSE INTERCALATED WITH MINOR LIMESTONES (SCHIST AND MARBLE) SCHWAGERINA SHUAGHUENSIS 